\title{
RELATIVE VALUATION OF ALTERNATIVE METHODS OF TAX AVOIDANCE
}

\author{
Kerry Katharine Inger
}

Dissertation submitted to the faculty of the Virginia Polytechnic Institute and State University in partial fulfillment of the requirements for the degree of

\author{
Doctor of Philosophy \\ In \\ Accounting and Information Sciences \\ C. Bryan Cloyd (Committee Chair) \\ Thomas B. Hansen \\ Sattar A. Mansi \\ Debra A. Salbador \\ W. Eugene Seago
}

April 30, 2012

Blacksburg, Virginia

Keywords: Tax Avoidance, firm value, corporate governance 


\title{
RELATIVE VALUATION OF ALTERNATIVE METHODS OF TAX AVOIDANCE
}

\section{Kerry Katharine Inger}

\begin{abstract}
This paper examines the relative valuation of alternative methods of tax avoidance. Prior studies find that firm value is positively associated with overall measures of tax avoidance; I extend this research by providing evidence that investors distinguish between methods of tax reduction in their valuation of tax avoidance. The impact of tax avoidance on firm value is a function of tax risk, permanence of tax savings, tax planning costs, implicit taxes and contrasts in disclosures of tax reduction in the financial statements. My empirical results suggest that tax avoidance resulting from stock option tax benefits is positively associated with firm value, accelerated depreciation is not associated with firm value and deferral of residual tax on foreign earnings is negatively associated with firm value. Prior studies that find the positive association between firm value and tax avoidance is attenuated in poorly governed firms suggest the discount results from investor concern of managerial opportunism. Self-serving managers conceal diversion of tax savings from investors under the pretext that aggressive tax positions must be hidden from tax authorities in the financial statements. Under this theory transparent tax reduction methods that are clearly supported by the law should not be discounted by investors of poorly governed firms. However, I find that tax avoidance resulting from transparent stock option tax deductions is discounted in poorly governed firms, while tax avoidance derived from opaque deferral of the residual tax on foreign earnings is not, inconsistent with investors believing that managers are exploiting the compromised information environment associated with complex tax transactions.
\end{abstract}




\section{Dedication}

I dedicate this dissertation to my family. Matt, thanks for the support, sacrifice and understanding along the way. Marlowe, thanks for the perspective and smiles when I needed it most. Mom, Dad, Chris and Steve, thanks for the encouragement and support, both emotionally and financially. 


\section{Acknowledgements}

First, I thank Dr. Bryan Cloyd, my dissertation chair, for his direction throughout the doctoral program. Thank you for your time and energy over the past four years to get me to this point. I appreciate that you always are able to help me see things in new ways, both from an academic and life standpoint. It was an honor to work with you. I would also like to express my gratitude to Dr. Bowe Hansen, Dr. Sattar Mansi, Dr. Debra Salbador and Dr. Gene Seago for serving on my committee and providing with my helpful feedback as I completed this process. I am grateful to Patrick and Jing Fan for collecting the tax-haven data used in my dissertation. I would also like to thank Dr. Jack Maher for his guidance during my doctoral program.

Thank you to the Accounting and Information Systems department for the financial and administrative support that was provided for my academic program and research. Specifically, the Ronald J. Patten Scholarship, the Johnny R. Johnson Memorial Scholarship and the Floyd A. Beamis Scholarship greatly reduced the financial burden of my doctoral program. In addition, the Virginia Society of CPA's provided me with the Austin M. Cloyd, Matthew G. Gwaltney and Maxine S. Turner Doctoral Scholarship for which I am endlessly grateful and honored to represent three outstanding Hokies lost on April 16, 2007. I would also like to thank Katherine Caldwell, Phyllis Neece and Arnita Perfater for their assistance and support during my time at Virginia Tech.

I would like to acknowledge each of the exceptional doctoral students that I had the pleasure of sharing this experience with. First, I would like to thank my cohort Ryan Leece and Todd White. I could not imagine this journey without each of you and look forward to continuing the journey as colleagues. James Long welcomed me to Blacksburg and I look forward to a similar warm welcome to Auburn, thanks for your friendship. Additionally, several other students added to my experience in the doctoral program and enjoyment of life while in Blacksburg: Lasse Mertins, Rob Crossler, Mollie Adams, Megan McInerney, Chris Edmonds, Lucian Zelazny, Jennifer Edmonds, Becky Fay, Michele Meckfessel, Jim 
Penner, Owen Brown, Eric Negangard, Mike Ozlanski, Jon Pyzoha, Kathy Enget, Joanna Garcia, Gabe Saucedo, Alan Stancill, Nichole Wright, Brandon Ater, Christine Gimbar, John Lauck and Joe Rakestraw. It has been a pleasure getting to know each of you.

I would also like to thank my family. Matt, your love, patience and support for the last 14 years have been amazing. You are an awesome husband and dad and I look forward to sharing this life with you each day. Marlowe, thanks for being the shining light at the end of many hard days and for giving me perspective on what is important in life. Mom and Dad, thanks for your love and support, and for raising me to love education and to have the confidence required of this career. Tommy, thanks for being a great brother, true friend and someone I can always talk to. Chris and Steve, thanks for loving me like a daughter and your encouragement in the quest to be the next "Dr. Inger." Finally, I thank God for this wonderful life. 


\section{Table of Contents}

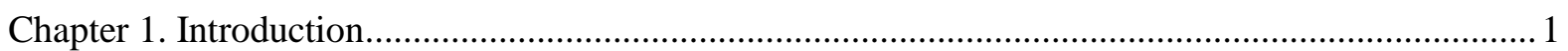

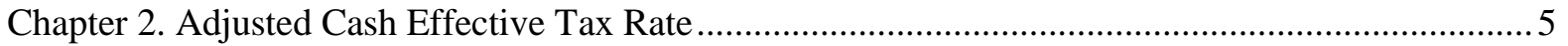

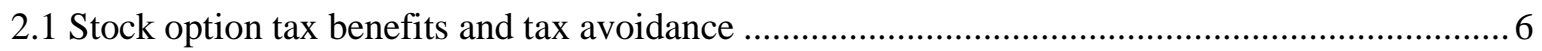

2.2 Accelerated tax depreciation deductions and tax avoidance .................................................. 9

2.3 Deferral of residual tax on foreign earnings and tax avoidance ........................................... 10

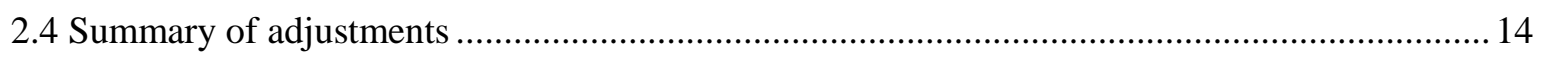

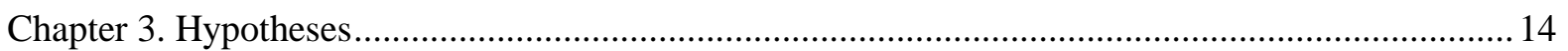

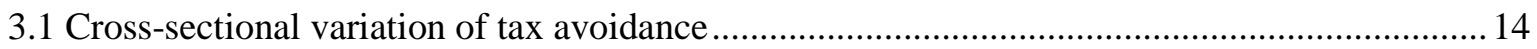

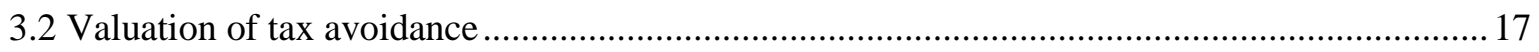

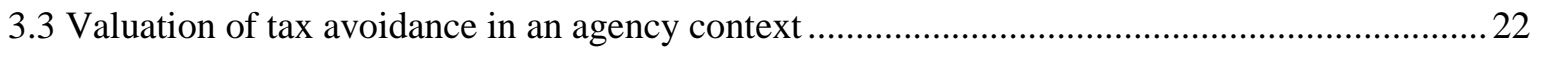

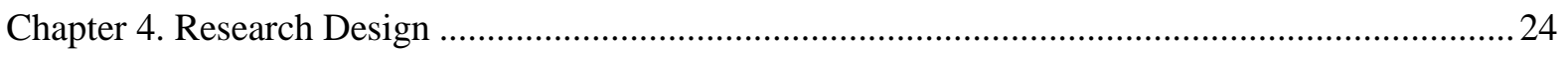

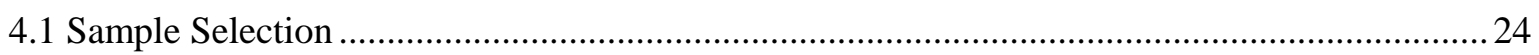

4.2 Descriptive Statistics for Hand Collected Data ....................................................................... 24

4.3 Descriptive Statistics for Tax Avoidance Measures ............................................................... 27

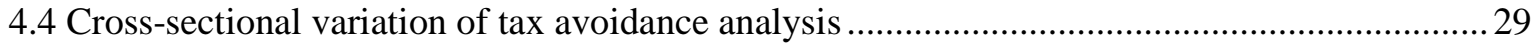

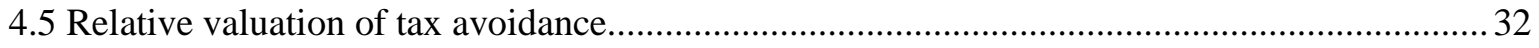

4.6 Relative valuation of tax avoidance in an agency context...................................................... 38

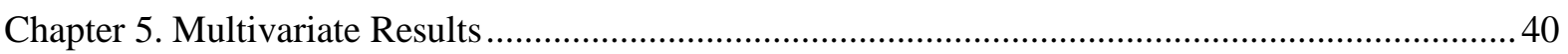

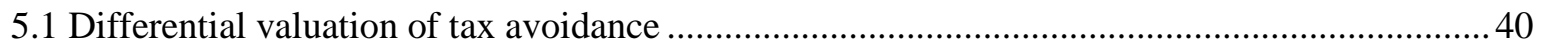

5.2 Differential valuation of tax avoidance in an agency context ................................................. 44

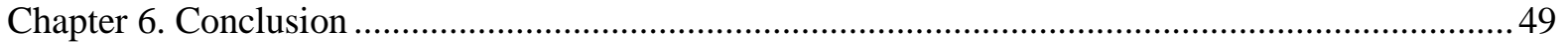

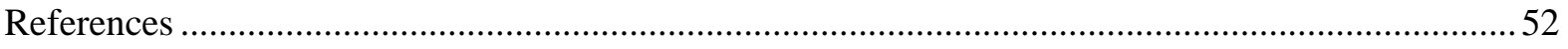

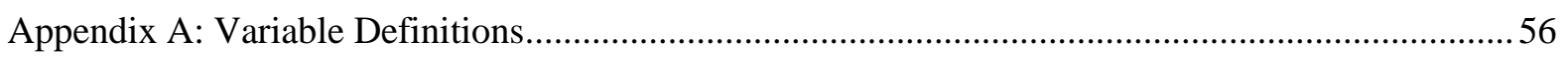

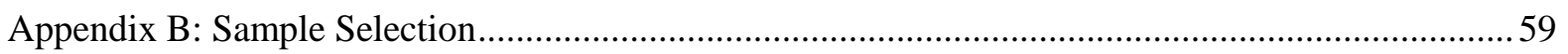

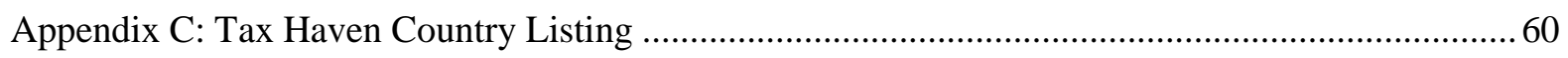

Appendix D: Illustration of Tax Avoidance Adjustments ................................................................ 61 


\section{List of Tables}

TABLE 1: Descriptive Statistics

TABLE 2A: Test of Adjusted Tax Avoidance Measures Relation to Traditional Control Variables using CETR3

TABLE 2B: Test of Adjusted Tax Avoidance Measures Relation to Traditional Control Variables using CETR

TABLE 3: Descriptive Statistics

TABLE 4: Descriptive Statistics for Dependent, Tax Avoidance and Control Variables in Tax Haven Firm Value Analysis

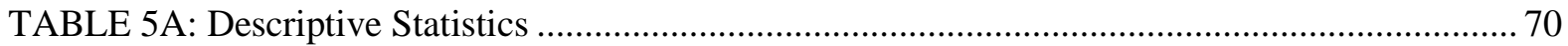

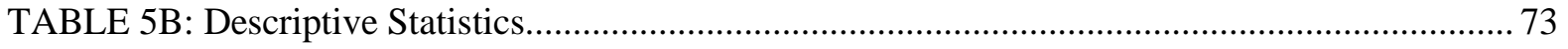

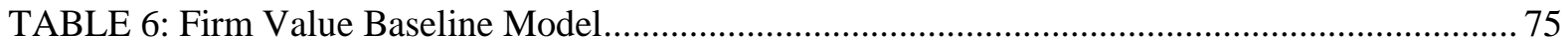

TABLE 7A: Firm Value and Alternative Methods of Tax Avoidance Model .................................... 76

TABLE 7B: Firm Value and Alternative Methods of Tax Avoidance Model - KRULL PRE TAX

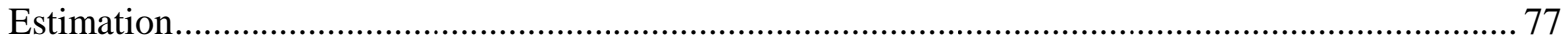

TABLE 8: Firm Value and Alternative Methods of Tax Avoidance Model including Tax Haven Interaction.

TABLE 9A: Firm Value and Alternative Methods of Tax Avoidance Model Expansion of Residual Tax Deferral

TABLE 9B: Firm Value and Alternative Methods of Tax Avoidance Model - KRULL PRE TAX Estimation Expansion of Residual Tax Deferral

TABLE 10A: Firm Value and Governance Baseline Model - G-Index

TABLE 10B: Firm Value and Governance Baseline Model - E-Index .....

TABLE 11A: Firm Value and Expanded Avoidance Measure Governance Models - G-Index.....

TABLE 11B: Firm Value and Expanded Avoidance Measure Governance Models - E-Index

TABLE 12: Firm Value and Expanded Avoidance Measure Governance Models - G-Index and Tax Havens

TABLE 13A: Firm Value and Alternative Avoidance Measure Governance Models - G-Index Expansion of Residual Tax Deferral

TABLE 13B: Firm Value and Alternative Avoidance Measure Governance Models - E-Index Expansion of Residual Tax Deferral 


\section{Introduction}

This paper examines the relative valuation of alternative methods of tax avoidance. Specifically, I examine two related research questions. First, do investors distinguish among methods of tax reduction in the valuation of tax avoidance? Second, is the relative valuation of tax avoidance a function of corporate governance mechanisms?

Corporate tax avoidance increases shareholder wealth to the extent that it increases the present value of expected future dividends. Recent studies find that tax avoidance is, on average, positively associated with firm value (Desai and Dharmapala 2009; Wilson 2009; among others). My study extends this literature by examining the relative valuation of alternative methods of tax reduction. The fact that different methods of tax avoidance involve varying risk profiles, permanent verses temporary tax reduction, tax planning costs, implicit taxes, and variation in disclosures in the financial statements of tax avoidance activities suggests differential valuation of specific methods of avoiding tax. Aggressive tax reduction schemes are associated with the risk of future costs (e.g. penalties and interest, cost of litigation, adverse publicity) that mitigate the value of tax avoidance to shareholders. Therefore, the value of tax avoidance to shareholders per dollar avoided is decreasing in risk. While some methods of tax reduction create permanent tax savings (i.e. stock option tax benefits), other methods reduce taxes in the current period at the expense of higher future taxes (i.e. accelerated tax depreciation deductions). The value to investors of permanent tax reduction is greater than temporary tax reduction. The benefits of tax planning are a function of the implementation costs and these costs vary with the complexity of the tax planning strategy. The value of tax avoidance is tied to the transaction or activity generating it. For example, bonus depreciation creates an implicit tax in the form of increased prices on certain types of assets (Key

2008), reducing the benefit of tax reduction. Due to the proprietary nature of tax returns, investors rely on tax disclosures in the financial statements to gather information about firms' tax avoidance and disclosures vary from vague (i.e. increase in reserve for uncertain tax positions) to straightforward (i.e. 
effective tax rate reduction from domestic manufacturing deduction). A premium may exist for tax avoidance when the source is clearly identifiable. These points suggest differential valuation across methods of tax avoidance.

Recent research suggests that poor corporate governance attenuates the positive relationship between tax avoidance and firm value (Desai and Dharmapala 2009; Wilson 2009), presumably because investors believe the benefits of tax avoidance are diverted to managers. Opacity in the financial statements is required for firms to conceal aggressive tax strategies from tax authorities. This opacity creates a compromised information environment enabling managers to divert the value of tax avoidance from shareholders. However, benign tax avoidance (e.g. stock option tax benefits and accelerated depreciation) does not require concealment from tax authorities to prevent detection because the tax positions are fully supported by the law and should not be associated with an opaque information environment conducive to diversion. Therefore, benign tax reduction should not be associated with a valuation discount. Isolating the type of tax reduction activities responsible for the differential valuation provides insight into why investors discount tax avoidance in poorly governed firms.

Traditional measures of tax avoidance, such as a corporation's cash effective tax rate (CETR) and total book tax differences, do not distinguish the activities creating the tax reduction. Studies that use these measures inherently treat all methods of tax avoidance the same. To study the relative valuation of tax avoidance, I focus on three specific methods of tax reduction: the tax benefits of stock option compensation, accelerated tax depreciation, and the deferral of the residual U.S. tax on foreign earnings. I select these items because they comprise a large portion of the book-tax gap (Desai 2003) and are important factors in assessing tax burdens. These methods of tax avoidance have different risk profiles, vary from temporary to permanent, and are associated with different levels of tax planning costs and implicit taxes; suggesting differential valuation. Additionally, these methods range from transparent (i.e. stock option tax benefits) to opaque (i.e. deferral of residual U.S. tax on foreign earnings), allowing for a test of whether investors in poorly governed firms only discount opaque tax reduction under the diversion 
theory of tax avoidance. My study utilizes hand collected data, requiring selection of tax avoidance methods that are commonly reported in firms' financial statements. These items are generally large enough to exceed the materiality threshold for financial statement disclosure.

Prior corporate tax avoidance studies include stock compensation, fixed assets, and/or foreign earnings as control variables (Ayers, Jiang, and Laplante 2011; Dyreng, Hanlon, and Maydew 2010; Desai and Dharmapala 2009) because these activities enable firms to reduce their tax burdens relative to other firms; however, inclusion of these control variables does not result in isolation of these activities from the tax avoidance measure. The value of option grants or exercises does not capture tax reduction from option exercises because deductible and non-deductible stock options are not distinguished, only the top five executives are included, and the stock price appreciation from grant to exercise determining the tax deduction is not accounted for. A firm's level of fixed assets is not indicative of the tax benefits of accelerated depreciation because the magnitude and sign of the book-tax difference is a function of the life cycle of the firm's assets. The impact of foreign earnings on observed tax avoidance depends on foreign tax rates, repatriation decisions, and the method of reporting the deferral of residual U.S. $\operatorname{tax}$ in the financial statements.

The CETR encompasses the entire range of the tax avoidance continuum, reflecting most tax planning strategies. My study uses hand collected data to isolate avoidance related to specific activities by adjusting the $C E T R$, allowing for study of alternative methods of tax avoidance. The CETR is selected because it is impacted by the three major categories of tax reduction examined in my study, its prevalent use to measure a firm's level of tax avoidance in recent studies, and its inclusion of both temporary and permanent tax planning strategies. Additionally, the CETR is not impacted by items such as the valuation allowance and tax rate changes that are not associated with changes to cash flow. Myers and Rajan (1998) argue that it is easier for managers to divert liquid assets than illiquid assets, suggesting that managers diverting tax savings are diverting cash or other fungible assets. My adjustments to the CETR result in an adjusted CETR unrelated to stock option tax benefits, accelerated tax depreciation, and 
deferral of the residual tax on foreign income and isolation of the level of tax avoidance associated with each of these methods of tax reduction.

I assess the importance of adjusting the CETR by examining the cross-sectional variation of tax avoidance implied by the adjusted and unadjusted measures. I observe a reordering of firms on the tax avoidance continuum, suggesting a different cross-sectional variation of tax behavior than implied by the traditional measure. This is an important finding because several recent studies (Ayers, Jiang, and Laplante 2011; Blaylock, Shevlin, and Wilson 2011) use the CETR to identify high tax avoidance firms. My study highlights the importance of selecting a measure of tax avoidance that is appropriate for the research question under examination, in the spirit of Hanlon and Heitzman (2010). For example, a measure of tax avoidance that is impacted by the tax benefits of stock options is not necessarily indicative of a firm's level of tax planning.

I examine whether prior studies' inferences about shareholder valuation of tax avoidance are primarily associated with total tax avoidance or if specific methods of tax avoidance have different valuation implications. Understanding the way investor's value different methods of tax reduction is an important extension of the research on the valuation of tax avoidance because some firms spend staggering amounts of money to engage in high-risk aggressive tax reduction strategies ${ }^{1}$ that investors may not view as value enhancing. Specifically, I find that tax avoidance resulting from stock option tax deductions is positively associated with firm value, accelerated tax depreciation deductions is not associated with firm value and deferral of the U.S. residual tax on foreign earnings is negatively associated with firm value. The discount on tax avoidance derived from deferral of the U.S. residual tax on foreign earnings is limited to firms with a presence in a tax-haven.

\footnotetext{
${ }^{1}$ A report about the role of professional firms in the U.S. tax shelter industry by the United States Senate committee of Homeland Security and Government Affairs (permanent subcommittee on investigations) reports that the SC2 (S-corporation charitable contribution strategy) tax shelter developed and promoted by KPMG had a minimum fee of $\$ 500,000$ and fees ranged as high as $\$ 2$ million dollars. The report also documents that the typical BOSS (Bond Option and Sales strategy) tax shelter promoted by PwC resulted in average fees of $\$ 400,000$ for a $\$ 10$ million dollar capital loss transaction.
} 
Of the types of tax avoidance examined in my study, stock option tax benefits provide permanent tax reduction, have the lowest risk, and the most transparent disclosure; suggesting the tax benefits should not be discounted in poorly governed firms under the diversion theory. Tax avoidance resulting from deferral of the residual tax is the least transparent, suggesting a discount in poorly governed firms under the diversion theory. However, I find that tax avoidance resulting from stock option deductions is discounted in poorly governed firms while tax avoidance from deferral of residual tax is not. These results are inconsistent with managers exploiting the compromised information environment associated with complex and opaque tax transactions to divert tax savings.

My study provides unique insight into how alternative methods of tax avoidance are associated with firm value. Demonstration of differential valuation of alternative methods of tax avoidance is an important extension to previous literature that focuses on overall tax avoidance (Desai and Dharmapala 2009) or narrow types of tax avoidance in isolation (Wilson 2009). A new method of measuring tax avoidance will allow researchers to focus on the type of tax avoidance that is appropriate for the research question under examination. In addition, my results add to the debate about tax avoidance in an agency context by providing evidence inconsistent with a discount on tax avoidance in poorly governed firms due to investor concern of self-serving managers diverting tax savings from complex and opaque tax transactions. Finally, my findings provide useful evidence to managers and boards of directors interested in equity investor perception of methods of reducing corporate income tax.

\section{Adjusted Cash Effective Tax Rate}

This section outlines the institutional details underlying my adjustments to the $C E T R^{2}$ and reviews the tax rules and accounting methods for the tax benefit of stock options, accelerated tax

\footnotetext{
${ }^{2}$ Following Dyreng, Hanlon, and Maydew (2008), the cash effective tax rate (CETR) is defined as: (Cash Income Taxes Paid/Earnings before tax and special items). Special items represent unusual and non-recurring items reported by the company above taxes on the income statement. All variable names are presented in italics. Tax avoidance measures are also presented in CAPS.
} 
depreciation deductions, and deferral of the residual U.S. tax on foreign income. Determining the impact each method of tax avoidance has on the CETR allows for the study of the relative valuation of alternative methods of tax reduction. Measuring tax avoidance in this way enables comparison of a one percent reduction in the CETR across methods.

\subsection{Stock option tax benefits and tax avoidance}

Non-qualified stock options (NQOs) generate a tax deduction for firms equal to the amount of ordinary income recognized by the employee upon exercise (the bargain element). Under FAS 123, effective for years beginning before June 15, 2005 for large publicly traded corporations, firms were required to recognize compensation expense for stock options in the financial statements only if the options had positive intrinsic value, thus there was generally no impact to net income from stock option compensation. ${ }^{3}$ The tax benefit was a direct to equity adjustment at the time of employee exercise; as a result the tax deduction reduced cash taxes paid with no corresponding reduction to book income, overstating tax avoidance implied by the CETR. In order to isolate tax avoidance related to stock option tax benefits from the measure, the cash tax benefit of stock options (Option Tax Benefit) is added to cash income taxes paid. Under FAS 123, the cash tax benefit of stock options (Option Tax Benefit: Reported), if material, should be reported as an adjustment in the operating section of the statement of cash flows (EITF 00-15 effective 2000) because the tax benefit of the stock options decreased cash taxes paid without a corresponding decrease to current tax expense.

FAS123R (ASC 718), effective for years beginning after June 15, 2005 for large publicly traded corporations, requires firms to recognize compensation expense for the estimated value of the options at

\footnotetext{
${ }^{3}$ A Bear Sterns report cited in Hanlon and Shevlin (2002) indicates that recognition of stock compensation expense under FAS 123 was rare. See Hanlon and Shevlin (2002) for a detailed discussion of accounting for the tax benefits of stock options under the FAS 123 regime. Few firms in my sample report stock option compensation expense prior to 2006.
} 
grant over the vesting period, creating a deferred tax asset. ${ }^{4}$ The future tax deduction reduces the deferred tax asset, with any difference ("windfall”) recognized in additional paid-in-capital. FAS 123R superseded EITF 00-15 and requires disclosure of the actual tax benefit realized from option exercises in the share based compensation footnote. In order to derive a post-123R adjusted CETR that is comparable to the pre-123R adjusted CETR, post 123R observations also require the addition of stock option compensation expense (123R Option Expense) to book income.

Following Kahle and Shastri (2005), I examine the statement of cash flows, statement of equity, share based compensation footnote and tax footnote for each firm for the disclosure of the stock option cash tax benefit. For firms that do not disclose the benefit or lump it with another number, such as "option exercises-net" on the statement of cash flows, I estimate the cash tax benefit from stock options using an approach provided in Hanlon and Shevlin (2002). They estimate the deduction as the number of options exercised multiplied by the difference between the weighted average exercise price of new grants during the year and the weighted average exercise price of options exercised during the year. The weighted average exercise price of new shares granted during the year is a proxy for the fair market value of the shares that were exercised during the year because grants are generally issued at the fair market value on the grant date. Multiplying the estimated deduction by the statutory rate (i.e. 35\%) provides an estimate of the cash tax benefit from stock option exercises (Option Tax Benefit: Estimated). ${ }^{5}$ The number of shares exercised, the weighted average exercise price of new grants, and options exercised during the year is available on Compustat beginning in 2004 and hand collected from the share based compensation footnote for years prior to 2004. Stock option compensation expense (123R Option Expense: Reported) is hand collected from the share based compensation footnote. ${ }^{6}$ For firms that do not

\footnotetext{
${ }^{4}$ FAS123R changed the financial accounting treatment for stock options; there was no change in tax laws governing stock option tax deductions.

${ }^{5}$ Graham, Lang, and Shackelford (2004) use a similar approach.

${ }^{6}$ Compustat provides the annual stock compensation expense (DATA \#398, STKCO); however this amount includes compensation for other forms of stock based compensation, such as restricted stock. The growing popularity of restricted stock limits the use of annual stock compensation expense as a proxy for stock option compensation expense.
} 
report stock option compensation expense for years after 123R, I estimate the expense (123R Option Expense: Estimated) by dividing the prior year's disclosed unrecognized stock option compensation expense (i.e. unvested stock option expense) by the disclosed vesting period for the options. To summarize, my adjustment to derive an adjusted CETR unrelated to stock option tax benefits is as follows:

CETR NO STOCK =

(Cash Income Taxes Paid + Option Tax Benefit)/(Earnings before tax and special items $+123 \mathrm{R}$ Option Expense)

For example, Microsoft's 2004 statement of cash flows reported income taxes paid of approximately $\$ 2.5$ billion and stock option income cash tax benefit of approximately $\$ 1.1$ billion. Microsoft's unadjusted CETR is $20.5 \%$, isolating the impact of the stock option tax benefit results in an adjusted CETR of $29.6 \%$.

In contrast to my adjustment to the CETR to remove the impact of tax avoidance related to stock option tax benefits, the use of a measure of stock options (e.g. value of stock option grants to executives as a fraction of their total compensation in Desai and Dharmapala (2009); total value of option exercises in Dyreng et al (2010)) as a control variable does not remove the actual impact of stock option tax benefits from the measure. First, the stock price appreciation from grant to exercise, determining the firm's tax deduction, is not captured. Additionally, stock compensation data for the top five executives as reported in Execucomp disregards option compensation for all employees except the top five compensated executives. Babenko and Tserlukevich (2009) estimate that $89 \%$ of options are held by nonexecutives and Desai (2003) reports that only $24 \%$ of shares granted are to the top five executives. Lastly, the use of the value of option grants or exercises does not distinguish between deductible nonqualified options and non-deductible incentive stock options. Adjusting the CETR is an improved method of isolating tax avoidance related to the tax benefits of stock options. 


\subsection{Accelerated tax depreciation deductions and tax avoidance}

Under the Modified Accelerated Cost Recovery System (MACRS) the default method for depreciating personal property for tax purposes is double declining balance; in contrast, the majority of firms use straight-line depreciation for financial reporting purposes. Economic stimulus packages often contain bonus depreciation provisions that further accelerate tax depreciation deductions. These factors result in larger tax depreciation deductions than book depreciation expense in the early years of an assets life. A deferred tax liability is recorded for the excess of tax depreciation over book depreciation (DTL $P P E)$. Cash taxes paid are reduced by the tax depreciation deduction, while pre-tax income is reduced by book depreciation expense. In order to isolate tax avoidance related to accelerated tax depreciation deductions from the CETR, I add the change in the deferred tax liability on property, plant and equipment to cash taxes paid. My adjustment to derive an adjusted CETR unrelated to accelerated tax depreciation is as follows:

CETR NO DEPR =

(Cash Income Taxes Paid $+\Delta$ DTL PPE)/(Earnings before tax and special items)

For example, in 2003 Home Depot reported income taxes paid of approximately \$2 billion and an increase in the deferred tax liability for accelerated depreciation of \$543 million. Home Depot's unadjusted CETR is $29.8 \%$, reversing the impact of accelerated tax depreciation results in an adjusted CETR of $37.7 \%$.

Many studies (Chen, Chen, Cheng, and Shevlin 2010; Dyreng et al 2010; among others) include fixed assets as a control variable in cross-sectional analyses of tax avoidance; however, a firm's level of fixed assets is not necessarily indicative of the tax reduction resulting from accelerated tax depreciation deductions. The asset's stage in the life cycle, selected useful life for book purposes, and type of property (i.e. real or personal property) determines the direction and magnitude of the book-tax difference. The allocation of property across jurisdictions also impacts the tax benefit from fixed assets because MACRS 
only applies to property located in the United States and state bonus depreciation conformity causes differences in state tax depreciation deductions. Adjusting the CETR is an improved method of isolating tax avoidance associated with accelerated tax depreciation deductions.

\subsection{Deferral of residual tax on foreign earnings and tax avoidance}

The United States imposes income tax on a corporation's worldwide income, including the income of subsidiaries incorporated in foreign countries. A foreign tax credit or deduction is allowed for foreign income taxes paid to mitigate double taxation, generally resulting in residual U.S. income tax ("residual tax") only on foreign income that is taxed at a foreign rate lower than the U.S. statutory rate. The residual tax is not due until the foreign subsidiary repatriates the foreign earnings to the U.S. parent through a dividend. Deferral of the residual tax allows U.S. firms doing business abroad to operate in a tax-neutral environment with their foreign competitors.

A firm's repatriation and deferral behavior has implications on the observed level of tax avoidance implied by the CETR. ${ }^{7}$ Deferral of the residual tax affects the level of tax avoidance implied by the CETR because the residual tax is not included in cash taxes paid whereas the related foreign earnings are included in book income. Tax avoidance implied by the CETR is also impacted in the period of repatriation because the residual tax is included in cash taxes paid whereas the related foreign earnings have been previously recognized in book income. The tax accounting approach utilized by a firm determines the adjustment required to remove the deferral of the residual tax from the CETR.

Generally there are two (not mutually exclusive) different tax accounting approaches for firms that do not repatriate foreign subsidiary earnings. Under the first approach, "PRE/Defer", the indefinite reversal criteria of Accounting Principles Board Opinion 23 allows firms to assert that unremitted foreign

\footnotetext{
${ }^{7}$ Foreign earnings remitted in the period earned result in current recognition of the residual tax in the financial statements and tax return ("Provide/Pay"). This approach does not impact the CETR because the tax is accrued and paid in the same period the foreign income is recognized in book income.
} 
earnings are permanently reinvested $(P R E)$ in the foreign jurisdiction and no accrual of the residual tax is required. An estimate of the tax liability for the residual U.S. tax that would be due if the earnings were repatriated $(P R E T A X)$ is a required disclosure under FAS 109 paragraph 44. The amount disclosed should include the impact of foreign tax credits. My adjustment to obtain an adjusted CETR unrelated to disclosure of unrecognized liability under the "PRE/Defer" approach is as follows.

\section{CETR NO PRETAX DISCLOSED =}

(Cash Income Taxes Paid $+\Delta$ PRE TAX Disclosed)/(Earnings before tax and special items)

FAS 109 paragraph 44 provides an exception to the disclosure of the unrecognized liability, allowing firms to state that determination of the liability is impracticable and many firms do not disclose an amount. Two methods for estimating the residual tax (PRETAX: Estimate) are provided in the literature. Krull (2004) estimates the liability by multiplying the change in PRE by the difference between the statutory rate (35\%) and the cumulative five-year foreign effective tax rate (FETR5), estimated as current foreign taxes divided by foreign earnings before taxes summed from year $\mathrm{t}-1$ to $\mathrm{t}-5$. Bauman and Shaw (2008) use the cumulative three-year FETR to gross up PRE by 1 less the FETR3 to determine the pre-tax foreign earnings that are permanently reinvested. The result is multiplied by the difference between the statutory rate and the FETR3 (.35 less FETR3) to estimate the residual U.S. tax. For both estimation methods, I set the estimate of PRETAX to zero for firms that have estimated foreign tax rates above the statutory rate because these firms would not owe residual tax on repatriation. I use the observations reporting the unrecognized liability on unremitted foreign earnings to compare the two estimation methods. The Bauman and Shaw (2008) estimation method is closer to disclosed amount more often than the Krull (2004) method. In addition, the mean and standard deviation of the absolute difference between the estimate and disclosed amount is smaller utilizing the Bauman and Shaw (2008) method. ${ }^{8}$ Based on this analysis, I use the Bauman and Shaw (2008) method to estimate PRETAX for

\footnotetext{
${ }^{8}$ The Bauman and Shaw (2008) method is closer to the disclosed amount for 182 out of 400 observations. The Krull (2004) method is closer 73 out of 400 observations. There are many ties due to setting the liability to zero
} 
firms that disclose PRE but do not disclose PRETAX. Results are robust using the Krull (2004) method and presented in supplementary tables. My adjustment to the CETR to remove the impact of estimated residual tax deferral is as follows:

$$
\text { CETR NO PRETAX ESTIMATE }=
$$

(Cash Income Taxes Paid $+\Delta$ PRE TAX Estimated)/(Earnings before tax and special items)

As an alternative to permanently reinvesting earnings, firms provide for the estimated residual tax in the financial statements, recognizing deferred tax expense and a deferred tax liability (DTL FOR). Under the "Provide/Defer" approach, taxes are avoided on the tax return, but not in the financial statements. My adjustment to the CETR to remove the impact of deferring the residual tax under the "Provide/Defer" approach is as follows:

\section{CETR NO PROVIDE $=$}

(Cash Income Taxes Paid $+\Delta$ DTL FOR $/($ Earnings before tax and special items)

While some firms specifically report the deferred tax liability on unremitted foreign earnings (e.g. Apple, Inc. 2010), others report the total deferred tax liability for foreign subsidiaries (e.g. Microsoft Corporation 2009). The total deferred tax liability related to foreign subsidiaries reflects the difference between the parent's book and tax basis in the investment in the subsidiary ("outside basis difference"). Unremitted foreign earnings cause an outside basis difference because foreign earnings are included in book income, increasing the book basis, with no corresponding increase to the tax basis until the earnings are repatriated. ${ }^{9}$ Although the change in the deferred tax liability reported for foreign subsidiaries

when the FETR is greater than the statutory rate and estimating the residual tax at $35 \%$ for observations with a FETR equal to 0 . The mean absolute difference between (standard deviation of) the disclosed and estimated amount is $\$ 68.34$ million (185.398) and $\$ 84.73$ million (203.223) for the Bauman and Shaw (2008) and Krull (2004) methods respectively.

${ }^{9}$ Unremitted foreign earnings represent only one component of the outside basis difference. Other components of the outside basis difference may include items such as cumulative translation adjustments and other comprehensive income items. A decrease in the outside basis difference indicates a repatriation of foreign earnings, but could also signal a sale, liquidation or merger of the subsidiary. PwC (2007) notes that the outside basis 
measures the residual U.S. income tax to be paid with error for firms reporting the overall deferred tax liability on foreign subsidiaries, it is a useful proxy given the available data.

I hand collect PRE, PRETAX and DTL FOR data from firm's 10-K tax footnotes. ${ }^{10}$ Firm year observations that report foreign earnings are permanently reinvested without disclosing a dollar amount ("amount not disclosed") are removed from the analysis because the adjustment cannot be calculated. The adjustments to unwind the "PRE /Defer" and "Provide /Defer" approaches are combined to produce one CETR measure of tax avoidance unrelated to the deferral of the residual tax on foreign earnings: ${ }^{11}$

\section{CETR NO RESIDUAL=}

$($ Cash Income Taxes Paid $+\Delta$ PRETAX $+\Delta$ DTL FOR $) /($ Earnings before tax and special items $)$

For example, in 2009 Amgen's disclosed unrecognized liability increased by $\$ 1.3$ billion and the deferred tax liability on unremitted foreign earnings increased by $\$ 13$ million, suggesting the residual U.S. tax was not accrued or paid on a large amount of foreign earnings. Amgen's unadjusted CETR is $12.9 \%$, reversing the impact of the deferral of residual tax results in an adjusted CETR of $30 \%$.

Several recent studies (Chen et al 2010; Dyreng et al 2010; among others) include foreign earnings as a control variable in cross-sectional analysis of tax avoidance because prior research finds there is a significant association between tax avoidance and foreign operations; however, the inclusion of foreign earnings as a control variable does not remove the impact of deferral of the residual tax from the tax avoidance measure. The impact of foreign operations on the CETR depends on the foreign tax rates imposed on foreign earnings, the ability to utilize foreign tax credits, repatriation decisions, and the

difference most frequently exists as a result of unremitted earnings and the largest component of the difference is generally unremitted earnings.

${ }^{10}$ Some firms report permanently reinvested earnings in the significant accounting policies footnote.

${ }^{11}$ In the normal course of business firms may determine that permanently reinvested earnings no longer meet the indefinite reversal criteria even though the foreign earnings will not be currently repatriated. In this situation the unrecognized tax liability will decrease with a corresponding increase to the deferred tax liability on unremitted foreign earnings. Firms may determine that foreign earnings for which the residual tax has previously been provided are now permanently reinvested. In this situation the deferred tax liability on unremitted foreign earnings will decrease with a corresponding increase to the unrecognized tax liability. The use of one measure accounts for both of these scenarios. Splitting the measures allows for the study of the relative valuation investors place on the financial accounting disclosure of the deferral of residual tax on foreign earnings. 
method of accounting for the deferral of the residual tax. Adjusting the CETR is an improved method of isolating tax avoidance related to the deferral of the residual tax.

\subsection{Summary of adjustments}

The overall adjustment to the measure of tax avoidance, as described in detail in this section (equations 1-3d), is summarized below:

Adjusted CETR =

$($ Cash Income Taxes Paid + Option Tax Benefit $+\Delta$ DTL PPE $+\Delta$ PRETAX +

$\Delta$ DTL FOR $) /($ Earnings before tax and special items + 123R Option Expense)

\section{Hypotheses}

\subsection{Cross-sectional variation of tax avoidance}

Whether the adjustment to the CETR impacts the cross-sectional variation of tax avoidance implied by the unadjusted measure is an empirical question. Although stock option deductions, the differential treatment of depreciation, and reporting of foreign source income comprise a large part of the book tax gap, it is unknown whether these items impact firms' observed level of tax avoidance in similar or different ways. The substitutability of tax shields may result in a similar overall adjustment to the CETR among firms even though the adjustment results from differing degrees of the three activities. A firm with a high level of stock compensation and no foreign activity may experience a similar total adjustment to the measure of tax avoidance as a firm with no stock compensation and a large foreign presence. A reordering of firms on the tax avoidance continuum reveals a different cross-sectional variation of tax avoidance than implied by the traditional measure, suggesting that the CETR is not appropriate for all tax avoidance research questions. I analyze the impact that the adjusted CETR has on the cross-sectional variation of tax avoidance to test my first hypothesis, stated in the null. 
Hypothesis 1: The adjustment to the CETR does not result in a reordering of firms on the tax avoidance continuum.

To further explore the impact the adjustments have on tax avoidance implied by the CETR, I examine the adjustments for the three tax avoidance methods individually. It is important to understand the impact each of the activities has on the cross-sectional variation of tax avoidance in order to appropriately tie the measure of tax avoidance to the research question of interest.

Although stock option tax deductions can significantly reduce the amount of tax a firm pays, tax benefits are not the main motive for stock option grants (Babenko and Tserlukevich 2011). While it is important to consider the tax benefits of stock options in assessing a firm's tax burden, it is not appropriate to consider the tax benefits of stock options in assessing a firm's level of tax aggressiveness because the tax deductions resulting from employee option exercises are clearly supported by the law and associated with an activity undertaken primarily to compensate employees. A research question concerning a firm's level of tax planning or concealment of tax reduction strategies from tax authorities and investors should not use a measure of tax avoidance that is affected by stock option tax benefits if there is cross-sectional variation in the impact the tax benefits have on the measure of tax avoidance. The tax benefits of stock options are dependent upon a variety of factors, including the type of options used, stock price appreciation, and employee vesting and exercise behavior. Babenko and Tserlukevich (2009) report disparity in the tax benefits of stock options; in 2005 tax deductions from stock options comprise on average $14.9 \%$ of EBIT for S\&P 500 firms and 77.9\% of EBIT for Nasdaq 100 firms. Hanlon and Shevlin (2002) offer examples of firms with sizeable profits whose tax benefit from stock options allow them to pay little or no tax. Dyreng, Hanlon and Maydew (2008) note that a group of firms in the Business Services industry are likely on the list of the lowest 25 CETR firms due to their heavy use of stock options. Graham, Lang, and Shackelford (2004) estimate that in 2000 aggregate deductions for stock options exceeded aggregate pre-tax income for Nasdaq 100 companies, but only comprised $10 \%$ of 
pre-tax income for S\&P 100 companies. Evidence from these studies suggests a material cross-sectional variation in the tax benefits of stock options.

Accelerated tax depreciation reduces current tax in a benign manner, causing overstatement of aggressive tax avoidance implied by the CETR in the early years of a fixed asset's life cycle. A research question concerning tax behavior at the most aggressive end of the tax avoidance continuum should not use a measure of tax avoidance that is affected by accelerated tax depreciation deductions if there is crosssectional variation in the impact the tax deductions have on the measure of tax avoidance. Differences in capital intensity result in some firms benefiting from accelerated depreciation more than others. The allocation of property across jurisdictions also impacts the tax benefit from fixed assets because MACRS only applies to property located in the United States and state bonus depreciation conformity causes differences in state tax depreciation deductions. ${ }^{12}$ The selected useful life for book purposes, type of property (i.e. real or personal property) and age of fixed assets also impact the direction and magnitude of the book-tax difference. These points suggest a material cross-sectional variation in the tax benefits from accelerated tax depreciation.

A research question concerning tax avoidance on U.S. source income should not use a measure of tax avoidance affected by the deferral of residual tax on foreign income if there is cross-sectional variation in the impact the deferral has on the measure of tax avoidance. Bauman and Shaw (2008) state that half of the S\&P 500 firms report PRE in their 2003 10-K's and the ratio of PRE to the market value of equity for firms disclosing the unrecognized liability ranges from $3.1 \%$ in the first quartile to $10.7 \%$ in the third quartile. Albring, Dzuranin, and Mills (2005) report that approximately $41 \%$ of corporations disclosing PRE in 2002 have foreign tax rates less than the statutory tax rate, suggesting variation in whether firms reporting $P R E$ would owe tax upon repatriation. The divide between firms reporting $P R E$

\footnotetext{
${ }^{12}$ Assets in foreign countries are depreciated under the Alternative Depreciation System ("ADS") requiring the $150 \%$ declining balance method. States differ in their adoption practices of federal bonus depreciation.
} 
and the variation in the materiality of the levels of $P R E$ reported suggests adjusting for the deferral of the residual tax will result in a reordering of firms on the tax avoidance continuum.

\subsection{Valuation of tax avoidance}

Tax avoidance signals to investors that management is actively seeking to divert money from the tax authorities to the firm and should be viewed as a positive net present value creating activity. Desai and Dharmapala (2009) document that tax avoidance has a positive effect on firm value in the presence of high institutional ownership. Their measure of tax avoidance, the difference between book income and inferred taxable income ${ }^{13}$, does not distinguish the types of activities creating the book-tax difference. Additionally, their measure excludes stock option tax benefits and foreign activities, thus no insight can be gained on the association between firm value and these activities.

Two studies examine a more narrow type of tax avoidance and find that investors positively value aggressive tax avoidance. Wilson (2009) finds that well governed firms exhibit positive abnormal returns during the period of active tax shelter involvement, as well as 24 months before and after engagement in the tax shelter. Koester (2011) shows that investors value uncertain tax positions, measured by the disclosed contingent liability for uncertain tax positions under FIN 48. While these studies provide evidence that aggressive tax behavior is positively valued by investors, they do not address whether investors differentially value specific methods of tax avoidance.

I present four primary reasons why investors would not value a dollar of tax savings the same across all methods of tax avoidance: (1) varying risk profiles across tax reduction strategies, (2) permanent verses temporary nature of tax savings, (3) differing tax planning costs and implicit taxes, and (4) contrasts in disclosure of tax avoidance activities.

\footnotetext{
${ }^{13}$ Desai and Dharmapala (2009) infer taxable income by grossing up current federal tax expense by the U.S. federal corporate tax rate. For firms with positive current federal tax expense, the graduated tax rate schedule is used. For firms with negative current federal tax expense, the top statutory rate of $35 \%$ is used.
} 
The tax avoidance continuum ranges from evasive tax reduction strategies to benign tax avoidance. Aggressive tax positions risk being overturned upon audit and expose firms to penalties and interest. Additionally, investors are likely to believe that managers willing to cheat the government will also cheat the owners of the firm. The risks associated with tax aggressiveness, including stock price crash risk identified in $\mathrm{Kim}, \mathrm{Li}$, and Zhang (2010) and the stock price decline associated with news coverage about tax shelter involvement documented in Hanlon and Slemrod (2009), may lead investors to discount the value created from aggressive tax reduction strategies compared to benign tax avoidance. Brown, Drake, and Martin (2011) show that firm's value tax avoidance achieved through low risk methods, specifically firms that avoid the largest amount of taxes with the lowest risk reward CEO and CFO's with larger bonuses. These points suggest that the value of tax avoidance should be a function of the risk associated with the method of tax reduction.

The benefits from permanent tax avoidance are greater than temporary tax avoidance. Specifically, permanent tax reduction results in a dollar-for-dollar benefit, whereas the benefit of tax deferral is limited to the time value of money. Recent studies document managerial incentives to reduce effective tax rates via permanent reduction, but find no evidence of managerial incentives to defer taxes (Robinson, Sikes, and Weaver 2010, Armstrong, Blouin, and Larcker 2010). Koester (2011) finds that investors favorably value permanent uncertain tax avoidance, while temporary uncertain tax avoidance is not valued. Although Ayers, Laplante, and Schwab (2011) provide evidence that deferral enhances firm value, the study does not address whether the deferral enhances firm value at the same rate as permanent tax reduction.

The costs of tax planning vary across types of tax avoidance. For example, the tax reduction resulting from stock compensation comes at a lower tax planning cost than the tax reduction resulting from a transaction engaged primarily to avoid taxes. Implicit taxes also affect the true benefit of tax avoidance and distort the tax savings generated from certain activities. For example, investors pay an implicit tax on municipal bonds in the form of a lower rate of return, reducing the true tax benefit of the 
tax exempt investment. Investors should discount tax avoidance that comes at a higher implementation cost or is associated with an implicit tax.

Investors do not have access to proprietary tax returns and must rely on financial statements to acquire information on a firm's tax avoidance activities. Certain tax avoidance activities are clearly disclosed in the tax footnote (i.e. accelerated depreciation), while other tax avoidance activities have less straightforward disclosure or are not disclosed at all, due to immateriality or a more sinister need to conceal the position from tax authorities. Investors may discount tax avoidance if the source of the reduction is unclear.

In sum, whether investors differentially value specific methods of tax avoidance is an empirical question, leading to my second hypothesis, stated in alternative form.

Hypothesis 2: Investors differentially value specific methods of tax avoidance.

I examine the relative valuation of three specific methods of tax avoidance: the tax benefits of stock options, accelerated tax depreciation deductions, and deferral of the residual U.S. tax on foreign subsidiary income. These items comprise a large portion of the book-tax gap (Desai 2003) and are commonly reported in firms' financial statements. In addition, these methods of tax avoidance vary in the characteristics I identified as reasons why investors would differentially value tax avoidance.

The tax benefits from stock compensation are low risk and permanent in nature, implying favorable valuation by investors. Furthermore, stock options do not require high tax planning costs and the tax benefits are transparent in the financial statements. While there is no direct evidence on the valuation of the tax avoidance arising from stock option tax deductions, the results of Mehran (1995) and Hanlon, Rajgopal and Shevlin (2004) show that equity based compensation is positively associated with firm performance. Further, Kahle and Shastri (2005) report that firms with tax benefits from stock 
options are more profitable and have more growth opportunities. It follows that the tax benefits from stock compensation are positively associated with firm value.

Hypothesis 3A: Firm value is positively associated with tax avoidance generated through stock option tax deductions.

Accelerated depreciation deductions result in temporary tax savings and are associated with implicit taxes in the form of increased asset prices (Key 2008). Conversely, accelerated depreciation tax deductions are low risk, reducing tax in a benign manner. Raedy et al (2011) find that the deferred tax liability on property, plant, and equipment is marginally value relevant for firms in the transportation and utility industry, but is not value relevant in a broader set of firms. The value of tax avoidance from accelerated depreciation deductions is a function of firm specific costs of capital and rates of return. Firms with a higher cost of capital and higher rate of return will benefit more from tax deferral (i.e. borrowing from the government), ceteris paribus. The reversal period of the timing difference also impacts the value of tax avoidance from accelerated depreciation.

Recently, economic stimulus packages have contained provisions for further acceleration of depreciation deductions. The tax reduction from accelerated tax depreciation would be discounted if investors believe the firm was incentivized to purchase superfluous assets because of immediate expensing under bonus depreciation. While Ayers, Laplante, and Schwab (2011) provide evidence that overall tax deferral enhances firm value; it is not clear whether deferral resulting from accelerated depreciation deductions is positively valued. In sum, there is mixed evidence on how the tax benefits from accelerated depreciation are associated with firm value, leading to my next hypothesis, stated in the null.

Hypothesis 3B: Firm value is not associated with tax avoidance generated through accelerated tax depreciation deductions. 
Deferral of the residual tax on foreign income results in quasi-permanent tax savings, as the firm determines whether and when the residual tax is paid. The risks associated with deferral of the residual tax vary and determination of these risks is difficult with information available in financial statements. Collins, Hand, and Shackelford (2000) find that the market positively values PRE and negatively values the disclosed unrecognized tax liability on unremitted foreign earnings. However, the valuation inferences about the unrecognized liability relate to the disclosure of the liability and not the tax deferral associated with $P R E$ because of the study's assumption that firms that do not disclose the liability will not owe tax upon remission. Bauman and Shaw (2008) show that the positive valuation of PRE declines as the expected residual tax liability increases, although the negative impact is smaller in firms for which the liability is estimated. Investors are found to positively value the tax deferral generated by $P R E$ once the impact of the unrecognized liability on the valuation of $P R E$ is accounted for.

Hypothesis 3C: Firm value is positively associated with tax avoidance generated through the deferral of the residual U.S. tax on foreign subsidiary income.

Results in prior studies suggest that aggressive tax behavior is associated with foreign operations in a tax-haven. Specifically, Lisowsky (2010) finds that the likelihood that a firm engages in a tax shelter, defined as a firm that reports a listed or reportable transaction in the IRS Office of Tax Shelter analysis, is positively related to the presence of a subsidiary located in a tax-haven. Alexander and Poe (2011) find that tax shelter intensity, measured as the beginning balance of gross uncertain tax positions, is positively associated with the number of subsidiaries located in a tax-haven. These findings are consistent with firms utilizing foreign subsidiaries in tax-havens to aggressively avoid tax through complex transfer pricing and intellectual property migrations.

Cloyd, Mills, and Weaver (2003) find that the reorganization of U.S. companies in tax-haven countries is not positively valued by the market and in some cases is associated with negative announcement period returns. The estimated non-tax costs of four corporate inversions in Cloyd et al 
(2003) suggest that the magnitude of non-tax costs of tax-haven operations might be relevant to shareholders. Alexander and Poe (2011) document that of firms disclosing PRE, only firms with subsidiaries in tax-havens have greater reserves for uncertain tax positions. Investors may discount tax avoidance resulting from deferral achieved in a tax-haven that is unlikely to be sustained upon audit. In addition, certain "island" tax-haven jurisdictions lack reinvestment opportunities, leading investors to believe that unremitted earnings will be repatriated and the residual tax will be incurred. For example, the reinvestment opportunities are likely more limited in the Cayman Islands tax-haven than in a larger nontax-haven market such as Canada. Negative publicity ${ }^{14}$ concerning tax-havens could result in a discount on tax avoidance from deferral in a tax-haven similar to the negative stock price reaction to news of involvement in a tax shelter identified in Hanlon and Slemrod (2009).

Hypothesis 3D: The association between firm value and tax avoidance generated by deferral of the residual U.S. tax on foreign income is lower in firms operating in a tax-haven.

\subsection{Valuation of tax avoidance in an agency context}

Recent studies document that the relation between firm value and tax avoidance does not hold in poorly governed firms (Desai and Dharmapala 2009; Cheng, Huang, Li, and Stanfield 2010; Wang 2011). These studies do not examine the type of tax avoidance causing the valuation differential. My study investigates whether the differential valuation of tax avoidance across governance levels is associated with total tax avoidance or if only certain methods of tax avoidance are discounted by investors of poorly governed firms.

Prior literature attributes the discount on tax avoidance in poorly governed firms to managerial diversion. Diversion requires a compromised information environment that management asserts is

\footnotetext{
${ }^{14}$ For example, a CBS 60 Minutes episode airing March 27, 2011 highlighted the use of tax havens in Switzerland. The town of Zug was reported to have a population of 26,000 residents and 30,000 companies, including the headquarters of Transocean, the drilling company associated with the BP oil spill. The only employee of Transocean present at the Swiss headquarters was a secretary.
} 
necessary to conceal aggressive tax strategies from tax authorities; therefore, the compromised information environment should be more strongly associated with aggressive tax avoidance. Benign tax avoidance, such as the tax benefits from stock options and accelerated depreciation deductions, results from tax positions fully supported by tax law. Therefore, management is not able to disguise benign tax reduction in the financial statements from investors under the pretext of concealment from tax authorities. Under the diversion theory, the transparent tax benefits from stock options and accelerated depreciation should not be discounted by investors in poorly governed firms.

Hypothesis 4A: The association between firm value and tax avoidance generated by stock option tax deductions and accelerated tax depreciation deductions does not vary across levels of corporate governance.

While no studies examine how governance impacts the valuation of the deferral of residual tax, insight can be gained from studies on PRE, cash and tax avoidance. Foley, Hartzell, Titman, and Twite (2007) find that the tax burden of repatriations is positively associated with firms' level of cash, suggesting the greater the tax deferral from PRE, the larger level of overall corporate cash holdings. Dittmar and Mahrt-Smith (2006) find that cash is valued significantly less in poorly governed firms than well governed firms. Investors in poorly governed firms may discount the value of taxes avoided by deferring repatriation of foreign earnings because of the value destruction associated with cash in poorly governed firms. Bryant-Kutcher, Eiler, and Guenther (2008) find that the lower valuation of PRE associated with disclosing the unrecognized tax liability is concentrated in firms with high amounts of excess cash. Dhaliwal, Huang, Moser, and Pereira (2011) find that tax avoidance negatively impacts investor valuation of firm cash holdings in poorly governed firms. The results of these studies suggest that the lower valuation of tax avoidance observed in poorly governed firms could be associated with investors perception of the increased overseas cash holdings resulting from taxes avoided through PRE. Of the three types of tax avoidance examined in my study, deferral of the residual tax is the least transparent and has the highest level of risk. Under the diversion theory, residual tax deferral is the most 
likely method of tax avoidance examined in my study to be discounted by investors in poorly governed firms, leading to my next hypothesis.

Hypothesis 4B: The association between firm value and tax avoidance generated by deferral of the residual U.S. tax on foreign income is lower in poorly governed firms than well governed firms.

\section{Research Design}

\subsection{Sample Selection}

My study focuses on the largest U.S. multinational firms by selecting the sample from the 2005 Fortune 500 over the period 1997-2010. The necessary data for the adjustments to the CETR were hand collected from10-K filings on EDGAR and company websites. Additional stock price information from CRSP, financial data from Compustat, executive compensation data from Execucomp, governance data from Risk Metrics and 10-K filing dates from Audit Analytics are utilized for valuation and control variables. Tax-havens subsidiaries are identified using a text search program.

The sample of hand collected observations is reduced from 7,000 (Fortune 500 over 14 year period 1997-2010) to 5,813 observations for the following reasons; 44 firms are excluded for specific reasons, including firms organized as Limited Partnerships or private companies, 298 firm year observations are lost because firms do not exist for the entire 14 year period, 230 firm year observations are lost because form 10-K's are unavailable on Edgar or the firm's website, 27 firm year observations are excluded due to bankruptcy filings and 16 firm year observations are lost because of missing total assets in Compustat. Sample selection is summarized in Appendix B.

\subsection{Descriptive Statistics for Hand Collected Data}


Descriptive statistics for hand collected data are provided in Table 1, Panel A and correlation coefficients are presented in Table 1, Panel B. ${ }^{15}$ The cash tax benefit from stock option exercises (Option Tax Benefit: Reported) is reported by $35.8 \%$ of firm year observations with a mean level of $\$ 60.027$ million. Microsoft reports a cash tax benefit from stock option exercises of $\$ 5.53$ billion in 2000 , the largest amount reported in the sample. Necessary data to estimate the benefit (Option Tax Benefit: Estimated) following Hanlon and Shevlin $(2002)^{16}$ is available for $87.8 \%$ of firm year observations with a mean value of $\$ 31.216$ million. Utilizing the estimate for firms not disclosing the amount results in a value for Option Tax Benefit for $100 \%$ of firm year observations with a mean of $\$ 36.155$ million.

\section{[Insert Table 1]}

Stock option compensation expense is reported (123R Option Expense: Reported) by $58.9 \%$ of firm year observations under FAS 123R (i.e. time period 2006-2010) with a mean value of $\$ 38.214$ million. Microsoft reports stock option compensation expense of $\$ 1.137$ billion in 2009, the largest amount reported in the sample. Necessary data to estimate the expense (123R Option Expense: Estimated) is available for $26.6 \%$ of FAS $123 \mathrm{R}$ firm year observations. ${ }^{17}$ Utilizing the estimated measure for firms not reporting the amount results in a value for $123 R$ Option Expense for $74 \%$ of firm year observations under FAS123R with a mean value of \$40.276 million. Observations missing stock option compensation expense under FAS123R are removed from further analyses because the adjustment cannot be calculated.

\footnotetext{
${ }^{15}$ Level statistics are reported for firm year observations reporting the variable and change statistics include all observations. Missing values are set to zero for change variables unless otherwise noted because firms that do not report an amount are assumed not to have a material amount of that variable.

${ }^{16}$ In addition to the estimation procedure the cash tax benefit from stock options is set to zero for firm year observations reporting zero option exercises or when the weighted average exercise price of options exercised exceeds the weighted average exercise price of options granted (i.e. underwater options).

${ }^{17}$ The estimation procedure (dividing the unrecognized compensation expense by the vesting period) results in a mean value of $\$ 48.339$ for 307 firms not reporting stock option compensation expense. This mean is significantly greater than the mean reported option expense of $\$ 38.214$ at $\mathrm{p}=.0921$. The estimation procedure results in a mean value of $\$ 35.23$ when applied to all 542 firms (including those that report stock option compensation expense) with data necessary for the calculation. This mean is not significantly different than the mean reported option expense of $\$ 38.214$ at $\mathrm{p}=.5933$. The 307 firms that have estimated option expense but no reported option expense are smaller (total assets), have similar levels of income, growth and age, and have slightly larger tax benefits from stock options. Results are robust to exclusion of these firms from the analysis.
} 
A deferred tax liability for property, plant, and equipment (DTL PPE) is reported by $88.8 \%$ of firm year observations with a mean level (change) of \$760.681 million (\$52.332 million). Exxon Mobil reports a deferred tax liability for property, plant and equipment of $\$ 42.65$ billion in 2010, the largest amount reported in the sample.

Approximately $50.7 \%$ of firm year observations in the sample report $P R E$ with a mean level (change) of $\$ 2.445$ billion ( $\$ 168.56$ million). General Electric reports $\$ 94$ billion of PRE in 2010, the largest amount reported in the sample. The unrecognized residual tax is reported (PRETAX: Reported) by $11 \%$ of firm year observations (approximately $22 \%$ of firms reporting PRE report PRETAX) with a mean level of $\$ 354.253$ million. Microsoft reports PRETAX of $\$ 9.2$ billion in 2010 on PRE of $\$ 29.5$ billion, the largest amount of PRETAX reported in the sample. The variables necessary to estimate PRETAX utilizing the Bauman and Shaw (2008) and Krull (2004) methods are available for $41 \%$ of firm year observations. Utilizing the Bauman and Shaw (2008) estimate of PRETAX (PRETAX: Estimate) for firms not disclosing the amount results in a value for PRETAX for $44 \%$ of firm year observations with a mean level (change) of $\$ 326.756$ (\$25.141) million. The percentage of firms reporting PRE is similar to that reported in Bauman and Shaw (2008), however the mean levels of PRE and PRETAX are greater. ${ }^{18}$

A deferred tax liability on unremitted foreign earnings (DTL FOR) is reported by $43.3 \%$ of firm year observations with a mean level (change) of $\$ 68.361(\$ 5.774)$ million. Pfizer reports a deferred tax liability on unremitted foreign earnings of $\$ 9.524$ billion in 2010 , the largest amount reported in the sample.

SEC registrants are required to list in Exhibit 21 the state or foreign jurisdiction of incorporation or organization of all significant subsidiaries, defined as subsidiaries in which the parent has a greater than $10 \%$ interest. Countries are identified as a tax-haven following Dyreng and Lindsey (2009) and provided in Appendix C. Tax-haven subsidiaries are identified using a text search program that scans

\footnotetext{
${ }^{18}$ Limiting my sample period to the Bauman and Shaw (2008) time frame results in more consistent mean values for PRE and PRETAX.
} 
exhibit 21 of form $10-\mathrm{K}$ for each firm in the sample. ${ }^{19}$ Firms that do not file exhibit 21 are assumed to not have a presence in a tax-haven. Approximately $44 \%$ of firm year observations have at least one subsidiary located in a tax-haven. On average firms with a presence in a tax-haven operate in 5.2 unique tax-haven jurisdictions and have 20.5 total subsidiaries located in tax-havens.

\subsection{Descriptive Statistics for Tax Avoidance Measures}

I measure tax avoidance, CETR AVOID, as the difference between the statutory corporate income tax rate of $35 \%$ and the CETR. Using the adjustments to the CETR discussed in section 2, I partition CETR AVOID into four components; tax avoidance derived from stock option tax benefits (STOCK AVOID), accelerated tax depreciation (DEPR AVOID), residual tax deferral (RESIDUALAVOID), and the remaining unexplained difference between the statutory rate and the CETR (OTHER AVOID). For example, STOCK AVOID is the difference between the CETR and CETR NO STOCK. ${ }^{20}$ All tax avoidance variables are defined in Appendix A.

The adjustments to the CETR require one lag year, thus 338 observations from 1997 are dropped from the analysis. A negative CETR reflects firms that have not paid tax or have negative pre-tax income. This profile does not correspond to a firm that has incentives to avoid taxes. For example, Sunoco Inc.'s CETR was approximately $-66 \%$ in 2010 on positive earnings due to a $\$ 526$ million refund from a net operating loss carryback. Sunoco appears highly aggressive based on the CETR, removal of the refund results in a CETR of approximately $27 \%$, altering the tax avoidance profile. A CETR greater than 1 indicates an unlikely situation where a firm is paying more than a dollar of tax per dollar of income and such observations are removed due to the lack of meaning in the measure. For example, Pitney Bowes' CETR was approximately $138 \%$ in 2006 due to a \$1.1 billion IRS tax settlement for years through 2000.

\footnotetext{
${ }^{19}$ I greatly acknowledge the assistance of Patrick and Jing Fan in gathering the tax-haven subsidiary data.

${ }^{20}$ Tax Avoidance related to stock option tax benefits (STOCK AVOID) can also be defined as: Option Tax Benefit/(Earnings before tax and special items + 123R Option Expense).
} 
Removal of the settlement from cash taxes paid results in a CETR of approximately $24 \%$, altering the tax avoidance profile. Observations with an unadjusted CETR below zero (425 observations) and over one (92 observations) are dropped from the analysis. ${ }^{21}$ Removing observations missing stock option compensation expense under 123R, reporting "amount not disclosed" for PRE and missing other necessary control variables reduces the sample to 3,273 firm year observations. Sample reduction is detailed in Appendix B. The mean CETR for the sample is $24.66 \%$.

The CETR can be distorted when measured over a one year period due to the variation in timing of cash tax payments and tax refunds. A long-run approach is employed to mitigate this concern, and tests are run using a long-run unadjusted and adjusted CETR accumulated over a three year period (“CETR3”). The adjustments to the CETR3 require three lag years, thus 1,048 observations from 19971999 are dropped from the analysis. The sample is further reduced by 240 observations with a CETR 3 less than zero and 58 firm year observations with a CETR3 greater than one. Removing observations missing stock option compensation expense under 123R, reporting "amount not disclosed" for $P R E$, and missing other necessary control variables reduces the CETR 3 sample to 2,612 firm year observations. The mean CETR3 for the sample is $23.41 \%$.

Descriptive statistics for the individual and overall adjustments are provided in Table 1 Panel C. The mean level of total unadjusted tax avoidance implied by the one year rate, CETR AVOID, is $10.49 \%$ and the three year rate, CETR AVOID3, is $10.49 \%$. The mean level of tax avoidance that is related to the stock option tax benefits, STOCK AVOID (STOCK AVOID3), is $2.19 \%$ (2.51\%). The mean level of tax avoidance related to accelerated tax depreciation, DEPR AVOID (DEPR AVOID 3), is 3.32\% (3.549The mean level of tax avoidance related to the deferral of the residual tax on foreign earnings, RESIDUAL AVOID (RESIDUAL AVOID 3), is $1.62 \%$ (1.08\%). An illustration of the adjustment methodology is provided in Appendix D.

\footnotetext{
${ }^{21}$ Other studies censor the CETR at [0,1]. Censoring would distort the comparison of total tax avoidance (CETR AVOID) to the decomposed measures of tax avoidance (i.e. CETR AVOID $\neq$ OTHER AVOID + STOCK AVOID + DEPR AVOID + RESIDUAL AVOID).
} 


\subsection{Cross-sectional variation of tax avoidance analysis}

To determine whether the cross-sectional variation of tax avoidance changes when the specific methods of tax reduction are removed from the CETR, I perform a ranking analysis. The first analysis utilizes Kendall's rank correlation coefficient (Kendall's tau), a nonparametric measure of rank correlation, which compares the similarity of orderings of the data when ranked by the unadjusted and adjusted CETR. A tau value of $1(0)$ suggests perfect correlation (independence) between the orderings. The tau value for the comparison of the unadjusted and adjusted CETR is .5008 and CETR3 is .48934, suggesting a meaningful reordering of observations based on the overall adjustment. The tau value for the comparison of the unadjusted CETR (CETR3) and CETR NO STOCK (CETR NO STOCK3) is .86478(.85093), CETR NO DEPR (CETR NO DEPR3) is .5968(.58509), and CETR NO RESIDUAL (CETR NO RESIDUAL3) is .8598(.86675). Consistent with my prediction, accelerated depreciation results in a meaningful reordering of firms on the tax avoidance continuum based on Kendall's rank correlation coefficient. Contrary to my prediction, stock option tax benefits and residual tax deferral do not result in a meaningful reordering based on Kendall's rank correlation coefficient.

An alternative ranking procedure assesses the extent to which firms change deciles based on the CETR and the adjusted CETR. Reordering firms based on the adjusted CETR (CETR3) causes $72.74 \%$ (71.95\%) of firm year observations to change deciles. ${ }^{22}$ Additionally, $72.74 \%$ (45.62\%) of firm year observations from the lowest CETR (CETR3) decile move to a higher decile when ranked by the adjusted $\operatorname{CETR}(C E T R 3){ }^{23}$

Reordering based on the CETR NO DEPR (CETR NO DEPR3) causes $61.81 \%(63.99 \%)$ of firm year observations to change deciles, confirming the meaningful reordering based on the tau value.

Additionally, $43.11 \%$ (36.54\%) of firm year observations from the lowest CETR (CETR3) decile move to a higher decile when ranked by CETR NO DEPR (CETR NO DEPR3).

${ }^{22}$ Deciles are determined by year.

${ }^{23}$ Of the firm year observations that move to a higher decile based on the adjusted CETR (adjusted CETR3), $50.29 \%(40 \%)$ move one decile, $10.53 \%(6.4 \%)$ move two deciles and $39.18 \%(53.6 \%)$ move more than two deciles. 
Reordering based on the CETR NO STOCK (CETR NO STOCK3) causes $37.11 \%$ (38.44\%) of firm year observations to change deciles and reordering based on the CETR NO RESIDUAL (CETR NO RESIDUAL3) causes $31.18 \%$ (33.9\%) of firm year observations to change deciles, suggesting a more meaningful reordering than the tau value. Additionally, $12.24 \%$ (14.1\%) of firm year observations from the lowest CETR (CETR3) decile move to a higher decile when ranked by CETR NO STOCK (CETR NO STOCK3) and $12.5 \%$ (13.5\%) move to a higher decile when ranked by CETR NO RESIDUAL (CETR NO RESIDUAL3).

I next regress the unadjusted and adjusted tax avoidance measure on variables utilized in prior research to control for a firm's ability to reduce tax burden, specifically option compensation, property, plant, and equipment, and foreign earnings, resulting in the following models:

$$
\begin{aligned}
& \text { CETR AVOID }_{\text {it }}=\beta_{0}+\beta_{1} \text { Stock Option }_{i t}+\beta_{2} \text { PPE }_{\text {it }}+\beta_{3} \text { ForeignIncome }_{i t}+\varepsilon_{i t} \\
& \text { OTHER AVOID }_{\text {it }}=\beta_{0}+\beta_{1} \text { Stock Option }_{i t}+\beta_{2} \text { PPE }_{\text {it }}+\beta_{3} \text { ForeignIncome }_{i t}+\varepsilon_{i t} \\
& \text { SPECIFIC AVOID }_{\text {it }}=\beta_{0}+\beta_{1} \text { Stock Option }_{i t}+\beta_{2} \text { PPE }_{\text {it }}+\beta_{3} \text { ForeignIncome }_{i t}+\varepsilon_{i t}
\end{aligned}
$$

The dependent variable CETR AVOID measures the level of tax avoidance implied by the CETR as the difference between the statutory tax rate (i.e. 35\%) and the unadjusted CETR. The dependent variable OTHER AVOID measures the tax avoidance unrelated to stock option tax benefits, accelerated tax depreciation, and deferral of the residual tax as the difference between the statutory rate and the adjusted CETR. The dependent variable SPECIFIC AVOID measures the level of tax avoidance related to stock option tax benefits, accelerated tax depreciation, and deferral of the residual tax as the sum of the adjustments for stock option deductions, accelerated tax depreciation, and deferral of residual tax. Control variables are scaled by total assets and defined in Appendix A. The purpose of this test is to determine whether the adjusted measure of tax avoidance has parceled out the effect of the specific items. 
Table 2A reports the results of the analysis using the CETR3. The coefficient on Stock Options $\left(\beta_{1}\right)$ is positive and significant, consistent with stock compensation reducing tax burden. The coefficients on PPE and Foreign Income $\left(\beta_{2}\right.$ and $\left.\beta_{3}\right)$ are insignificant when CETR AVOID3 is the dependent variable, inconsistent with these items enabling tax burden reduction. The coefficients on Stock Options and PPE $\left(\beta_{1}\right.$ and $\left.\beta 2\right)$ are negative and significant when OTHER AVOID3 is the dependent variable and positive and significant when SPECIFIC AVOID3 is the dependent variable, suggesting the impact of stock compensation and property, plant and equipment have been isolated from the adjusted measure of tax avoidance. The coefficient $\beta_{3}$ is insignificant in each model, inconsistent with foreign income reducing tax burden and questioning isolation of foreign income from the adjusted measure of tax avoidance, warranting further investigation.

\section{[Insert Table 2A]}

I perform such an investigation by replacing the dependent variable in equation $5 b(5 c)$ with tax avoidance unrelated (related) to the deferral of residual tax on foreign income, presented in Panel B. The coefficient $\beta_{3}$ is negative and significant when CETR NO RESIDUAL AVOID3 is the dependent variable and positive and significant when RESIDUALAVOID3 is the dependent variable, confirming isolation of foreign operations from the measure and consistent with higher levels of foreign income increasing avoidance related to deferral of the residual tax on foreign income. I also perform this analysis with regard to stock options and property, plant, and equipment, confirming the results from the initial analysis. Results are consistent using the one year cash effective tax rate, presented in supplementary Table 2B.

\section{[Insert Table 2B]}

Additionally, a comparison of the residuals from the models regressing CETR AVOID3 and OTHER AVOID3 on the explanatory variables results in a tau value of .50987, suggesting the unexplained variance changes with the use of the adjusted tax avoidance measure. These tests suggest that the cross- 
sectional variation of tax avoidance implied by the CETR and CETR 3 change as a result of adjusting the measure for stock option tax benefits, accelerated tax depreciation deductions, and deferral of the residual tax, providing evidence to reject the null hypothesis $\mathrm{H} 1$.

Comparing the residuals from the reduced models in Table 2A Panel B suggests that accelerated tax depreciation has the most meaningful impact on the cross-sectional variation of tax avoidance implied by the CETR 3 and stock option tax benefits and deferral of the residual tax have a weak impact.

Specifically, a comparison of the residual from the models regressing CETR AVOID3 and CETR NO DEPR AVOID3 on the explanatory variable PPE results in a tau value of .64115 , while the tau value is .85764 for CETR AVOID3 and CETR NO STOCK3 regressed on the explanatory variable Options and .87276 for CETR AVOID3 and CETR NO RESIDUAL3 regressed on the explanatory variable Foreign Income.

\subsection{Relative valuation of tax avoidance}

I examine the relative valuation of tax avoidance using the following model:

$$
\text { FirmValue }_{i t}=\beta_{0}+\beta_{1} \text { OTHER AVOID }_{i t}+\beta_{2} \text { STOCK AVOID }_{i t}+\beta_{3} \text { DEPR AVOID }_{i t}+
$$

$$
\beta_{4} \text { RESIDUAL AVOID }_{\mathrm{it}}+\sum \text { ControlVariables }_{\mathrm{it}}+\varepsilon_{\mathrm{it}}
$$

Firm value is measured by Tobin's $Q$, the ratio of the market value of the firm to book value of assets at year end. ${ }^{24}$ Tobin's $Q$ is selected as the measure of firm value because of its use in studies of the valuation of tax avoidance (Desai and Dharmapala 2009; Wang 2011; De Simone and Stomberg 2011) and its common use in other accounting studies, such as recent studies by Zhao and Chen (2008) who study the impact of staggered boards on firm value and Dey (2008) who studies the impact of agency

\footnotetext{
${ }^{24}$ Results are consistent measuring Tobin's Q based on the price one day and five days after the $10-\mathrm{K}$ filing using the 10-K filing date from Audit Analytics. It is not possible to measure total assets one or five days after the filing date.
} 
conflicts on firm value. Additionally, Tobin's $Q$ is used as a measure of firm value in the corporate governance studies that develop the G-Index (Gompers, Ishii and Metrick 2003) and E-Index (Bebchuk, Cohen and Ferrell 2009), making it an appropriate measure in analysis of the valuation of tax avoidance in an agency context. OTHER AVOID, STOCK AVOID, DEPR AVOID and RESIDUAL AVOID measure the tax avoidance related to each item as outlined in the adjustment methodology and summarized in Appendix A. The model allows for the comparison of the relative value investors place on different methods of tax reduction.

Control variables are employed in the model following prior literature and defined in Appendix A. The first set of control variables, Options, PPE, and Foreign Income ${ }^{25}$, isolate the impact of the specific types of tax avoidance on firm value. I include equity compensation (Options) because prior research (Morck, Shleifer, and Vishny 1988; Mehran 1995) finds that stock-based compensation is related to firm value and stock compensation allows firms to reduce their tax burden relative to other firms without stock-based compensation, ceteris paribus. In addition, controlling for stock compensation ensures that STOCK AVOID captures only the impact of the tax benefits of stock options on firm value. Following Dyreng et al (2010), I include a control variable for stock options measured as the average annual value realized from the exercise of options for the top five executives of options by the top five executives grossed up by the fraction of options owned by the covered executives (from Execucomp). ${ }^{26} \mathrm{I}$ include gross Property, Plant and Equipment $(P P E)$ to account for the association between fixed assets and firm value, ensuring the variable DEPR AVOID is capturing the impact of the tax benefits of accelerated depreciation on firm value. Pre-tax foreign income (Foreign Income) proxies for a firm's

\footnotetext{
${ }^{25}$ Correlation coefficients for firm value regression variables are provided in Table 3 Panel B. The Pearson correlation coefficients between STOCK AVOID3 and Options is .5297, DEPR AVOID3 and PPE is.334, and RESIDUAL AVOID3 and Foreign Income is .3996, suggesting the adjustments are correlated with the control variables, but not at a level to cause a multi-collinearity concern.

${ }^{26}$ Desai and Dharmapala (2009) and Wang (2011) utilize the ratio of the Black-Scholes value of stock options granted to the top five managers to the value of their total compensation as reported in Execucomp. The use of the grant value does not account for stock price appreciation from grant to exercise.
} 
international operations, ensuring RESIDUAL AVOID captures the impact of deferral of residual U.S. tax on firm value and not the impact of foreign operations on firm value.

Two additional control variables further ensure isolation of the impact of the specific methods of tax avoidance on firm value. Although the exercise of stock options indicates an increase in stock price, the exercise value does not fully account for the stock price appreciation from grant to exercise.

Controlling for the actual stock price appreciation associated with stock options exercised during the current year is not possible because of varying vesting periods (generally between two and seven years) and an unknown lapse of time between vest and exercise. I use the change in the stock price over the prior four year period as a control for stock price appreciation (Appreciation). Foley et al (2007) report that firms have higher levels of cash as the tax cost of repatriation increases. Including Cash as a control variable minimizes the possibility that RESIDUAL AVOID measures the impact of foreign cash holdings on firm value instead of the impact of tax avoidance from the deferral of the residual tax on firm value.

Following prior literature, I control for a variety of factors that are associated with Tobin's $Q$ and tax avoidance. I include sales as a control for firm size (Size) because of the association between Tobin's $Q$ and firm size demonstrated in prior literature (Morck, Shleifer and Vishny 1988). Sales is selected as a control for firms' size because of the mechanical relation between other controls for size, total assets and market value of equity, and Tobin's $Q$. Additionally, total assets are mechanically related to other control variables employed in the model (PPE, Cash and Intangible). I include a proxy for firms' growth opportunities (Growth), measured as the three year average sales growth, as a control variable because Tobin's $Q$ captures growth opportunities. I include stock price volatility (Risk) measured as the standard deviation of monthly returns over the prior 36 month period as a control for risk. Following Gompers et al (2003) I include the log of firm age as of December year t (Firm Age). As the substitutability of tax shields can impact the value of and incentive for engaging in tax avoidance, controls for debt (Leverage), book value of intangible assets (Intangible), and net operating losses (NOL) are included in the model. 
Descriptive statistics for dependent and control variables are presented in Table 3 Panel A and correlation coefficients are presented in Table 3 Panel B.

\section{[Insert Table 3]}

As tax avoidance is expected to vary across time and industries, year and industry dummies ${ }^{27}$ are included in the model. Industries are classified according to the thirteen industries in Barth, Cram, and Nelson (2001) and two additional industries identified in Rees and Sivaramakrishnan (2007). The model is estimated using ordinary least squares (OLS) and standard errors are adjusted for heteroskedasticity using robust standard errors clustered at the firm level (Petersen 2009). Additionally, all variables are winsorized at the $1 \%$ and $99 \%$ tails.

I believe a levels-based model is the appropriate research design to test my hypotheses relative to a changes-based model. Barth, Beaver, and Landsman (2001) state that value relevance studies examining price levels are "interested in determining what is reflected in firm value", while studies examining price changes are "interested in determining what is reflected in changes in value over a specific period of time.” My study examines whether information about methods of avoiding tax contained in the financial statements are used by investors in valuing firms equity. The stock price should be higher for firms that avoid tax, ceteris paribus, because the increase in cash flows provided by avoiding taxes increases expected future dividends. I predict that the impact tax avoidance has on firm value is a function of the methods of tax reduction.

Barth et al (2001) assert that studies examining whether an accounting amount is timely reflected in firm value should use a price change research design. Information on tax avoidance is made available periodically by firms and the extent of the information provided varies with the disclosure. Effective tax rates are disclosed each quarter and tax expense is provided in earnings announcements. For most firms,

\footnotetext{
${ }^{27}$ Four industries in my sample do not have sufficient firm year observations to constitute a separate dummy variable. Specifically, agriculture, pharmaceuticals, services and healthcare are underrepresented, having less than 200 firm year observations over the 14 year period. These industries are collapsed into a single industry.
} 
the tax information required to determine my adjustments to the CETR is only available in the $10-\mathrm{K} .^{28}$ For example, Coca-Cola does not disclose the cash tax benefit from stock options, the amount of foreign earnings that are permanently reinvested or deferred tax liabilities in their quarterly reports. Thus there is not an identifiable date that the information on a firm's tax avoidance becomes publicly available. The lack of timeliness in the disclosure of overall tax avoidance and variation of when information on tax avoidance methods becomes available to investors suggests that a levels-based design is more appropriate to study the impact of tax avoidance on firm value relative to a change-based design. ${ }^{29}$

Barth (2000) notes that an event study must identify the event date and specify an unexpected portion of the accounting variable of interest. Identification of expected tax avoidance is difficult because quarterly estimates of annual effective tax rates disclosed in firms' 10-Q's contain upward bias (Comprix, Mills and Schmidt 2011) and sophisticated users of financial statements have difficulty interpreting effective tax rate changes (Bauman and Shaw 2005). In addition, the variability of annual tax rates due to refunds, settlements and other tax irregularities limits the use of an annual rate as an expectation for a future year's rate. My study mitigates the variability of annual tax rates by measuring tax avoidance over a three-year period, further compounding the issue of identification of expected tax avoidance. The lack of an identifiable expectation of tax avoidance also suggests that a levels-based design is more appropriate.

In order to test Hypothesis 2, I examine the equality of the coefficients of the tax avoidance variables $\left(\beta_{1}-\beta_{4}\right)$. Inequality of the coefficients suggests differential valuation of methods of tax avoidance. In addition, I expect a positive coefficient on STOCK AVOID $\left(\beta_{2}\right)$ under Hypothesis 3A, an

\footnotetext{
${ }^{28}$ I am unable to locate these amounts in a small sample of Fortune 500 firm's quarterly reports. I have not examined the quarterly report of each firm during my sample period.

${ }^{29}$ Two studies on tax avoidance and firm value use a price change design. These studies have an identifiable event date. Specifically, Wilson (2009) uses abnormal returns surrounding tax shelter involvement and Hanlon and Slemrod (2009) use cumulative abnormal return calculated over a 3-day window surrounding the date of news of tax shelter involvement.
} 
insignificant coefficient on DEPR AVOID $\left(\beta_{3}\right)$ under the null Hypothesis $3 \mathrm{~B}$, and a positive coefficient on RESIDUAL AVOID $\left(\beta_{4}\right)$ under Hypothesis 3C.

In order to test Hypothesis 3D, I interact RESIDUAL AVOID with a measure of tax-haven presence. Specifically, Haven is set to 1 for firm year observations that have at least one subsidiary in a tax $_{\text {-haven }}{ }^{30}$. In addition, I include Haven as a control variable in the model to ensure the interaction of RESIDUAL AVOID and Haven measures the impact of tax avoidance derived from residual tax deferral in a tax-haven on firm value and not the impact of the presence of a tax-haven subsidiary on firm value. I expect a negative coefficient on the interaction of RESIDUAL AVOID and Haven under Hypothesis 3D.

A comparison of hand collected residual tax deferral and regression variables for tax-haven and no tax-haven observations is presented in Table 4. On average, tax-haven observations have significantly higher levels of $P R E$, estimated levels of PRE TAX and DTL FOR, although there is not a significant difference in the reported level of PRE TAX. While total tax avoidance is not significantly different, taxhaven observations have significantly higher levels of tax avoidance from residual deferral $(2.06 \%$ compared to $1.16 \%$ ) and no tax-haven observations have significantly higher levels of tax avoidance from accelerated depreciation ( $4.5 \%$ compared to $2.46 \%)$.

\section{[Insert Table 4]}

I further examine the valuation of the deferral of the residual tax by decomposing RESIDUAL AVOID into three components: (1) tax avoidance associated with the disclosed tax liability on permanently reinvested earnings (PRETAX DISCLOSED AVOID) derived from equation 3a, (2) tax avoidance associated with the estimated (undisclosed) tax liability on permanently reinvested earnings (PRETAX ESTIMATE AVOID) derived from equation 3b, and (3) tax avoidance associated with provision

\footnotetext{
${ }^{30}$ Publicly available information does not allow for the estimation of the amount of book income sourced to each subsidiary, making it impossible to determine the residual tax by foreign location. I use an indicator variable to measure tax-havens because Alexander and Poe (2011) find that the total number of tax-haven subsidiaries does not add explanatory power to their tax shelter intensity model.
} 
of an estimate of the residual tax through a deferred tax liability (PROVIDE AVOID) derived from equation 3c. Collins et al (2000) find that investors negatively value the disclosed unrecognized residual tax liability on foreign earnings, while Bauman and Shaw (2008) find that investors positively value the deferral of the residual tax. I address these contrasting results using the following model, expanded from Model 6:

$$
\begin{aligned}
& \text { FirmValue }_{i t}=\beta_{0}+\beta_{1} \text { OTHER AVOID }_{\text {it }}+\beta_{2} \text { STOCK AVOID } \beta_{3} \text { DEPR AVOID }_{i t}+ \\
& \beta_{4} \text { PROVIDEAVOID }_{\mathrm{it}}+\beta_{5} \text { PRETAX DISCLOSE AVOID }_{\mathrm{it}}+ \\
& \beta_{6} \text { PRETAX ESTIMATE AVOID }_{\mathrm{it}}+\sum_{\text {ControlVariables }}+\varepsilon_{\mathrm{it}}
\end{aligned}
$$

I test the equality of the coefficients on the decomposed residual tax deferral variables to determine whether investors differentially value methods of disclosing residual tax deferral.

\subsection{Relative valuation of tax avoidance in an agency context}

The agency analysis employs the model from the firm value analysis with the addition of governance interactions. Specifically, model 6 will be amended to include the interaction of poor governance with the tax avoidance measures:

$$
\begin{aligned}
& \text { FirmValue }_{\text {it }}=\beta_{0}+\beta_{1} \text { OTHER AVOID }_{\text {it }}+\beta_{2} \text { OTHER AVOID }_{\text {it }} * \text { PoorG }_{\text {it }}+\beta_{3} \text { STOCK AVOID }_{\text {it }} \\
& +\beta_{4} \text { STOCK AVOID }_{\mathrm{it}} * \text { PoorG }_{\mathrm{it}}+\beta_{5} \text { DEPR AVOID }_{\mathrm{it}}+\beta_{6} \text { DEPR AVOID }_{\mathrm{it}} * \text { PoorG }_{\mathrm{it}}+ \\
& \beta_{7} \text { RESIDUAL AVOID }_{\text {it }}+\beta_{8} \text { RESIDUAL AVOID*PoorG }_{i t}+\sum \text { ControlVariables }_{\text {it }}+\varepsilon_{i t}
\end{aligned}
$$

A measure of corporate governance, the G-Index (Gompers et al 2003), is used to determine if the relative value of tax avoidance varies across levels of corporate governance. The G-Index measures corporate governance using a point scale of the number of antitakeover provisions present in a firm, where each provision increases the index and a high score indicates poor corporate governance. Following prior studies of tax avoidance in an agency context (Wilson 2009; Wang 2011), firms with a G-Index score over(under) the sample mean are designated as poorly(well) governed firms such that the variable Poor $G$ is an indicator of poor governance. In addition, the designation of poor governance will 
be narrowed to firms in the highest quartile (decile) of the G-Index reported in the sample, specifically firms reporting a G-Index score above 12(14) will be designated as poorly governed firms. ${ }^{31}$ This method accounts for the possibility that poor corporate governance is a symptom of a smaller portion of firms than suggested by splitting at the sample mean. Finally, I assign strong and poor governance at the extreme quartiles and include a variable for strong governance (Strong $G$ ) interacted with each of the measures of tax avoidance. This governance assignment approach, motivated by Harford, Mansi and Maxwell (2008), focuses on the difference between the valuation of tax avoidance between firms exhibiting the strongest and weakest corporate governance, whereas the previous governance assignments focused on poorly governed firms compared to all other firms in the sample.

The G-Index is selected because of its use in prior studies of the valuation of tax avoidance in an agency context (Desai and Dharmapala 2009; Wilson 2009; Wang 2011; Koester 2011). The Entrenchment index developed by Bebchuk, Cohen, and Ferrell (2009) is used as a measure of corporate governance in recent accounting and finance studies. I present results using the Entrenchment index as a measure of corporate governance using the same governance assignment approaches in supplementary analyses.

Prior research finds that cash is valued less in poorly governed firms than well governed firms (Dittmar and Mahrt-Smith 2006). To ensure that the interaction of RESIDUAL AVOID and PoorG (deferral of the residual tax in poorly governed firms) is not capturing the impact of poor governance on the valuation of cash I include a control variable for cash in poorly governed firms $(C A S H * P O O R G){ }^{32}$

Descriptive statistics and t-tests for differences in means across levels of governance for dependent, tax avoidance and control variables are presented in Table 5A Panel A for the G-Index

\footnotetext{
${ }^{31}$ The range of G-Index scores in my sample is 3-16, although the G-Index can range from 0-24. Approximately $25.4 \%$ of the firms in my sample report a G-Index score above 12 and $7.5 \%$ report a G-Index score above 14. It is not possible to split the sample exactly at the mean, quartile or decile because of the discrete nature of the G-Index.

${ }^{32}$ I also include an interaction of Cash and Strong $G$ in the extreme quartile analysis.
} 
governance specifications and Table 5B Panel A for the E-Index governance specifications. Well governed firms have significantly larger amounts of tax avoidance derived from stock option tax benefits across all governance specifications, highlighting the importance of the Option control variable. Significance of differences in the other tax avoidance measures between well and poorly governed firms depends on the governance specification. Correlation coefficients are presented in Table 5A Panel B.

\section{[Insert Table 5A]}

[Insert Table 5B]

The coefficients on the tax avoidance variables $\left(\beta_{1}, \beta_{3}, \beta_{5}, \beta_{7}\right)$ now capture the impact of tax avoidance on firm value in well governed firms. The coefficients $\beta_{4}$ and $\beta_{6}$ are expected to be insignificant under Hypothesis 4A, suggesting investors do not differentially value tax avoidance related to the tax benefits of stock options and accelerated depreciation across levels of governance. The coefficient $\beta_{8}$ is expected to be negative and significant under Hypothesis $4 \mathrm{~B}$, suggesting investors of poorly governed firms discount the tax avoidance resulting from residual tax deferral compared to well governed firms. The relative valuation of tax avoidance across governance levels will be explored by testing the equality of the tax avoidance and governance interaction coefficients.

\section{Multivariate Results}

\subsection{Differential valuation of tax avoidance}

Multivariate results for the firm value models are presented in Tables 6 through 13. Collinearity diagnostics suggest the models do not have a multi-collinearity problem. Specifically, the variance inflation factor (VIF) is below 5 for all variables in the models and the condition index of all models are below 30. A VIF above 10 and/or a condition index above 30 is generally indicative of inflated standard errors resulting from a collinearity problem (Montgomery, Peck and Vining 2006). Results are robust to 
exclusion of influential observations identified following the methods provided by Belsley, Kuh, and Welsch (1980). ${ }^{33}$

A baseline model of the relation between firm value and tax avoidance implied by the unadjusted CETR is presented in Table 6. Panel A includes observations with the necessary data to calculate the CETR (CETR3) and control variables. Tax avoidance implied by the CETR and CETR3 is positively associated with firm value, specifically the coefficients on CETR AVOID and CETR AVOID3 (unadjusted tax avoidance) are significant at .05 and .0766 , respectively. Panel B includes observations with the necessary data to calculate all tax avoidance variables (i.e. STOCK AVOID, DEPR AVOID and RESIDUAL AVOID) and control variables. Observations with CETR3 greater than one or less than zero, missing stock option compensation expense after 2005 and reporting "amount not disclosed" for permanently reinvested earnings are excluded from the analysis. This sample is comparable to samples in future analyses of the relative valuation of different methods of tax avoidance. The association between firm value and tax avoidance implied by the CETR 3 is marginally significant at the $10 \%$ level. The coefficient on CETR AVOID is not significant in the reduced model, suggesting tax avoidance implied by the one year cash effective rate is not associated with firm value. Therefore, I limit discussion of results in future analyses to the cumulative three-year cash effective tax rate.

\section{[Insert Table 6]}

Expansion of the measure of tax avoidance into its components in Table 7A provides insight into the valuation of specific methods of tax avoidance. Specifically, the coefficient on STOCKAVOID3 is positive and significant ( $\mathrm{p}=.0178$ ), in support of Hypothesis 3A, suggesting tax avoidance resulting from the tax benefits of stock options is positively associated with firm value. The temporary deferral of tax

\footnotetext{
${ }^{33}$ Belsley, Kuh, and Welsch (1980) propose that observations meeting the following criteria possibly have a large influence on the parameter estimation and require further investigation: (1) $\mid$ Covariance ratio-1 $\mid \geq(3 p / n)$ where $\mathrm{p}$ is the number of parameters in the model and $\mathrm{n}$ is the number of observations used to estimate the model, (2) |Studentized Residual $\mid>2$, (3) DFBETA $>2 / \sqrt{ }$, and (4) DFITS $>2 / \sqrt{ } \mathrm{p} / \mathrm{n}$. Results are robust to exclusion of influential observations identified using these four criteria.
} 
resulting from accelerated depreciation is not associated with firm value as indicated by the insignificant coefficient on DEPR AVOID3 ( $\mathrm{p}=.7118$ ), suggesting there is no evidence to reject the null Hypothesis 3B. The coefficient on RESIDUAL AVOID3 is negative and significant ( $\mathrm{p}=.0045)$, contrary to $\mathrm{H} 3 \mathrm{C}$, suggesting the tax avoidance resulting from the deferral of the residual tax is negatively associated with firm value. This is consistent with investors viewing the unrecognized liability for the residual tax as an unbooked liability and valuing it accordingly. OTHER AVOID3 is positive and significant $(\mathrm{p}=.0763)$; however, no insight can be gained from this result because it is unknown what activities comprise this portion of tax avoidance.

\section{[Insert Table 7A]}

Comparison of coefficients on the tax avoidance variables reveals differential valuation of methods of tax avoidance, in support of Hypothesis 2. Specifically, the test of coefficient equality is rejected for each comparison of methods of tax avoidance. For example, the test of coefficient equality between STOCK AVOID3 and DEPR AVOID3 results in a p-value of .0215, demonstrating that the tax benefits of stock options are more positively valued by investors than accelerated depreciation deductions. Results are consistent using the Krull (2004) estimation procedure for PRE TAX and presented in supplementary Table 7B.

\section{[Insert Table 7B]}

Table 8 presents the results of the firm value analysis including tax-havens. The coefficient on RESIDUAL AVOID3, measuring the impact of residual tax deferral on firm value in observations with no tax-haven presence, is insignificant. The sum of the coefficients on RESIDUAL AVOID3 and RESIDUAL AVOID $3 *$ Haven, measuring the impact of residual tax deferral on firm value in observations with a tax-haven presence, is negative and significant. These results provide support for Hypothesis 3D and suggest that the discount on tax avoidance derived from residual tax deferral is limited to firms with a presence in a tax-haven. This result could be attributable to investor belief that the tax benefits of deferral 
in a tax-haven are not beneficial to shareholders because of the lack of reinvestment opportunities in the tax-haven. In order for the benefits of foreign profits to accrue to shareholders, tax-haven firms will have to repatriate and pay the residual tax, whereas firms with foreign profits in non tax-haven jurisdictions have more reinvestment opportunities and will not have to repatriate in order for the benefits of foreign activity to accrue to shareholders. Further examination of investor valuation of tax avoidance derived from residual tax deferral associated with tax-haven subsidiaries is left to future research.

\section{[Insert Table 8]}

Next I decompose RESIDUAL AVOID into the three accounting methods used to disclose the deferral of residual tax in the financial statements, presented in Table 9A. The coefficients on PROVIDE AVOID3 and PRETAX DISCLOSE AVOID3 are negative and significant ( $\mathrm{p}=.0838$ and .0474 , respectively), suggesting tax avoidance resulting from provision for the residual tax or disclosure of the amount of residual tax due upon remission of permanently reinvested earnings are negatively associated with firm value. The negative coefficient on PRE TAX DISCLOSE AVOID3 is consistent with Collins et al (2000) who report weak evidence of a negative association between current stock prices and the disclosed repatriation liability. In addition, the coefficients are not significantly different $(\mathrm{p}=.9406)$, suggesting the discount on tax avoidance is the same for providing for the residual tax or disclosing the amount due upon remission of permanently reinvested earnings. This is an interesting result because providing for the residual tax impacts the income statement, while disclosure of the unrecognized liability does not. Investors believe disclosure of the liability signals intent to repatriate and pay the tax and value the unrecognized liability accordingly. In contrast, the coefficient on PRETAX ESTIMATE AVOID3 is insignificant ( $\mathrm{p}=.2609)$, suggesting that the discount on tax avoidance related to deferral of the residual tax is isolated to disclosure of the estimated amount of tax due upon repatriation. This result is consistent with Bauman and Shaw (2008) who show that the negative impact of the repatriation liability is lower for firms that do not disclose the liability. Contrary to their results, I do not find that the estimated repatriation tax liabilities are positively associated with firm value. However, I use tax avoidance 
resulting from deferral instead of the level of the unrecognized liability as my independent variable of interest. In addition, my sample includes a larger number of observations over a longer time period and I use a different measure of firm value. Results are consistent using the Krull (2004) estimation procedure for PRE TAX and presented in supplementary Table 9B.

[Insert Table 9A]

[Insert Table 9B]

\subsection{Differential valuation of tax avoidance in an agency context}

Table 10A presents the results of a baseline analysis of the valuation of tax avoidance in an agency context using the G-Index (Gompers at al 2003) as a measure of corporate governance. In Panel A, I assign poor governance above the sample mean of 9.896 , resulting in 1,410 poor governance observations (approx. 54\%) and 1,202 strong governance observations (approx. 46\%). ${ }^{34}$ It is possible that poor corporate governance is not as widespread of a problem as splitting at the mean suggests, leading to an alternate assignment of poor governance above the third quartile (G-Index > 12) in Panel B and above the highest decile (G-Index > 14) in Panel C. The coefficient on CETR AVOID3 is positive across all specifications of governance; however the result is only significant when governance is defined at the mean (.097) and insignificant when governance is assigned at the third quartile (.1177) and highest decile (.1336). The association between firm value and tax avoidance in poorly governed firms is insignificant across all specifications.

Next I assign strong and poor governance at the extreme quartiles $($ Poor $G=$ G-Index $>12$ and Strong $G=$ G-Index $<8$ ) in Panel D. The results suggest that firm value is positively associated with tax avoidance in firms with the strongest corporate governance $(\mathrm{p}=.0663)$ and not in firms with average $(\mathrm{p}=.1592)$ or the poorest $(\mathrm{p}=.3289)$ levels of corporate governance.

\footnotetext{
${ }^{34}$ Due to the discrete nature of the G-index, it is not possible to split the sample exactly in half or by quartile or decile.
} 
[Insert Table 10A]

The results of the analysis using the E-Index (Bebchuk et al 2005) as a measure of corporate governance presented in supplementary Table 10B are generally consistent with the main analysis using the G-Index. ${ }^{35}$ Since prior studies on tax avoidance in an agency context use the G-Index as a measure of corporate governance, I limit discussion of remaining analyses to the G-Index measure of corporate governance unless results are inconsistent between the two measures of governance. Analyses using the E-Index are presented in supplementary tables.

[Insert Table 10B]

Table 11A presents the results of the expanded tax avoidance measures model in an agency context using the G-Index as a measure of corporate governance. Consistent with prior analysis, the coefficient on STOCK AVOID3 is positive and significant across all specifications of governance, demonstrating the tax avoidance resulting from stock options is positively associated with firm value in well governed firms. Contrary to Hypothesis 4A, the sum of the coefficients on STOCK AVOID3 and STOCK AVOID3 *Poor G (i.e. tax avoidance from stock option benefits in poorly governed firms) are not significantly different than zero in the mean, third quartile and extreme quartile samples $(\mathrm{p}=.1689$, $\mathrm{p}=.6592, \mathrm{p}=.6373$ respectively) and negative in the highest decile sample $(\mathrm{p}=.0192)$, suggesting a discount on tax avoidance derived from stock option tax deductions in poorly governed firms. This result is inconsistent with the managerial diversion explanation of the differential valuation of tax avoidance across governance levels because stock option tax benefits are transparent, clearly supported by tax law and not associated with the compromised information environment necessary to conceal tax avoidance from investors.

\footnotetext{
${ }^{35}$ The coefficient on CETR AVOID3 is significant at .0574 when governance is assigned at the top decile of the E-Index, while the coefficient was insignificant at 1336 when governance is assigned at the top decile of the GIndex. All other results are consistent.
} 
The coefficient on DEPR AVOID3 *PoorG is insignificant across all specifications of governance, indicating there is not differential valuation of tax avoidance derived from accelerated tax depreciation deductions across levels of governance and there is no evidence to reject the null Hypothesis 4A. Contrary to Hypothesis 4B, the coefficient on RESIDUALAVOID ${ }^{*}$ Poor G (i.e. value of deferral of residual tax in poorly governed firms) is not statistically significant across all G-Index governance specifications $^{36}$, suggesting investors of poorly governed firms do not further discount the tax avoidance resulting from deferral of the residual tax. This result is inconsistent with the diversion theory of tax avoidance in poorly governed firms because the discount is not observed on the most opaque type of tax avoidance examined in my study. In the extreme quartile sample, the sum of the coefficients on RESIDUAL AVOID3 and RESIDUAL AVOID3*Strong $G$ (i.e. tax avoidance derived from residual tax deferral in well governed firms) are not statistically different from zero. Investors in firms with the strongest governance structures do not discount the tax avoidance resulting from deferral of the residual tax. This result suggests that the differential valuation of tax avoidance across governance levels could be driven by firms with the strongest levels of governance instead of firms with the poorest levels of governance.

\footnotetext{
${ }^{36}$ The coefficient on RESIDUAL AVOID $3 *$ Poor $G$ is negative and significant in the third quartile and extreme quartile E-Index analyses presented in Table 11B, inconsistent with the results of the G-Index analysis. Harford et al (2008) find that the other factors in the G-Index not captured by the E-Index or classified boards provides information about a firm's cash holdings. As discussed earlier, the prediction that investors value deferral less in poorly governed firms is based on diverting cash overseas, suggesting the G-Index is a better measure to test Hypothesis 4A. The poorly governed firms in the G-Index third quartile sample report PRE TAX at a significantly lower rate than well governed firms. (16.05\% of poorly governed firms report PRE TAX and $23.32 \%$ of well governed firms report $P R E T A X$, difference is significant at .0035). There is not a significant difference between the reporting of $P R E T A X$ between poorly and well governed firms in the E-Index third quartile sample. (21.9\% of poorly governed firms report $P R E T A X$ and $19.53 \%$ of well governed firms report $P R E T A X$, difference is not significant at .3416). There is not a significant difference between reporting PRE TAX among poorly and well governed firms in the other governance assignments. In addition, the E-Index third quartile sample contains a higher percentage of poorly governed firms (25.38\% in G-Index sample verses $29.79 \%$ in E-Index sample) due to the discrete nature of the index preventing assignment of poor governance at exactly the third quartile of the E-Index. Approximately $25 \%$ of firms do not have the same governance classification between the G-Index and E-Index third quartile samples. Further differences between the G-Index and E-Index results, which are only observed in the third and extreme quartile governance assignments, are assumed to be due to the identified differences in governance assignments between the two samples.
} 
A comparison of the coefficients in Panel E reveals that the differential valuation of tax avoidance across methods is stronger in well governed firms than poorly governed firms. Specifically, the test of coefficient equality in well governed firms is rejected for each comparison across all governance specifications, showing that each method of tax avoidance is valued differently in well governed firms. When poor governance is defined above the mean and third quartile, only tax avoidance from the deferral of the residual tax exhibits differential valuation, which is not surprising since deferral was the only method of tax avoidance in poorly governed firms exhibiting a significant association with firm value.

[Insert Table 11A]

[Insert Table 11B]

Inclusion of an interaction between RESIDUAL AVOID3, Poor G and Haven in Table 12, Panel A reveals that the discount on residual tax deferral is limited to poorly governed firms operating in a taxhaven when poor governance is defined above the mean of the G-Index. Specifically, the association between firm value and tax avoidance derived from residual tax deferral in poorly governed firms with operations in a tax-haven is negative and significant (i.e. the sum of the coefficients on RESIDUAL AVOID3, RESIDUAL AVOID3*PoorG, RESIDUAL AVOID3*Haven and RESIDUAL AVOID3*Haven*PoorG); while the association is insignificant in well governed firms not operating in a tax haven (i.e. the coefficient on RESIDUALAVOID3), well governed firms with operations in a taxhaven and (i.e. sum of the coefficients on RESIDUAL AVOID3 and RESIDUAL AVOID3*Haven) and poorly governed firms not operating in a tax-haven (i.e. sum of the coefficients on RESIDUAL AVOID3 and RESIDUAL AVOID ${ }^{*}$ PoorG ). Results in Panel B suggest that the discount on residual tax deferral is greater in poorly governed firms operating in a tax-haven compared to other firms when poor governance is defined above the third quartile of the G-Index. Specifically, the association between firm value and tax avoidance derived from residual tax deferral in poorly governed firms with operations in a 
tax-haven is more negative (i.e. sum of the coefficients on RESIDUAL AVOID3, RESIDUAL AVOID3*PoorG, RESIDUAL AVOID3*Haven and RESIDUAL AVOID3*Haven*PoorG) than well governed firms not operating in a tax haven (i.e. the coefficient on RESIDUALAVOID3), well governed firms with operations in a tax-haven (i.e. sum of the coefficients on RESIDUAL AVOID3 and RESIDUAL AVOID $3^{*}$ Haven) and poorly governed firms not operating in a tax-haven (i.e. sum of the coefficients on RESIDUAL AVOID and RESIDUAL AVOID*PoorG).

[Insert Table 12]

Table 13A presents the results of the further decomposition of the deferral of the residual tax in an agency context. When poor governance is defined above the mean (Panel A), the negative association between firm value and tax avoidance related to disclosing the estimated residual tax, either providing a deferred tax liability or disclosing the unrecognized liability on permanently reinvested earnings, is only observed in poorly governed firms. Specifically, the coefficients on PROVIDE AVOID3 and PRETAX DISCLOSE AVOID3 are insignificant. These coefficients were negative and significant in the main analysis. Addition of the governance interaction terms (PROVIDE AVOID3 * PoorG and PRETAX DISCLOSE AVOID3 *PoorG) reveals a negative and significant association between firm value and disclosure of the estimated residual tax. The extreme quartile sample (Panel D) confirms this result; tax avoidance from disclosure of an estimate of the residual tax is negatively associated with firm value in poorly governed firms and not associated with firm value in firms with the strongest level of governance. The tax avoidance derived from permanently reinvesting foreign earnings and asserting estimation of the tax liability is impracticable is not associated with firm value in either well or poorly governed firms across all specifications of governance. This method of disclosing tax avoidance derived from deferral of the residual tax is the most opportune for diversion because of the opaque nature of the assertion that it is not practicable to estimate the liability, revealing much less information than provision of the tax or disclosure of the unrecognized liability. Instead the more transparent tax avoidance resulting from disclosure of an estimate of the residual tax on unremitted foreign earnings is discounted by investors in 
poorly governed firms. Results are generally consistent using the E-Index and presented in supplementary Table 13B.

[Insert Table 13A]

[Insert Table 13B]

\section{Conclusion}

This paper examines whether the relation between firm value and tax avoidance varies across alternative methods of tax avoidance. My analyses yield evidence consistent with investors distinguishing between the underlying activities creating tax reduction and valuing tax avoidance according to the risks, permanence of tax reduction, tax planning costs, implicit taxes, and financial statement disclosures of the method of tax avoidance. Specifically, I find that the tax avoidance arising from stock option tax deductions is positively associated with firm value, suggesting investors value the low-risk, permanent and transparent nature of this method of tax reduction. Tax avoidance generated through accelerated tax depreciation deductions is not associated with firm value, likely because of the temporary nature of the benefits and investor's concerns of implicit taxes and overinvestment associated with accelerated and bonus depreciation. Tax avoidance resulting from deferral of the residual U.S. tax on unremitted foreign earnings is negatively associated with firm value, consistent with investors treating the residual tax as an unbooked liability. The discount is only observed for firms with a presence in a taxhaven. The discount is also isolated to disclosure of the estimated residual tax due upon repatriation, both provision of deferred tax and disclosure of the unrecognized liability are negatively associated with firm value. The discount is not observed for estimated tax avoidance from permanently reinvested earnings for firms that state the unrecognized liability is not practicable to estimate.

I also examine whether the relation between firm value and alternative methods of tax avoidance varies as a function of firm's corporate governance structures. Prior studies posit that the lack of 
association between firm value and tax avoidance in firms with poor governance mechanisms results from managerial diversion. I argue that diversion requires a compromised information environment that should only be associated with tax avoidance requiring concealment from tax authorities. Therefore, under the diversion theory, tax avoidance that is clearly supported by the law and transparent in the financial statements should not be discounted by investors of poorly governed firms. I find that tax avoidance resulting from stock option deductions is discounted in poorly governed firms, inconsistent with the diversion theory. Deferral of the residual tax is the most complex and least transparent of the methods of tax avoidance examined in my study and under the diversion theory should be most likely to exhibit differential valuation across levels of governance. I do not observe a discount on the tax avoidance from overall residual tax deferral in poorly governed firms. In addition, the only method of disclosing residual tax deferral in the financial statements that is not differentially valued by investors is the estimation of the unrecognized liability on permanently reinvested earnings. This method of disclosing tax avoidance seems the most opportune for diversion because of the open-ended assertion that it is not practicable to estimate the liability, revealing much less information than provision of the tax or disclosure of the unrecognized liability. Instead investors of poorly governed firms discount the more transparent tax avoidance resulting from disclosure of an estimate of the residual tax on unremitted foreign earnings. Overall, my results are inconsistent with investors discounting tax avoidance in poorly governed firms because they believe managers will divert tax savings from opaque tax transactions.

My analysis highlights the importance of selecting a measure of tax avoidance appropriate for the research question under examination. I offer a new method of measuring tax avoidance that enables researchers to study specific methods of tax avoidance, an improvement over prior measures that focus on total tax avoidance. My study makes a significant contribution to the literature's understating of the association between firm value and tax avoidance. I use my method of measuring tax avoidance to examine the relative valuation of alternative means of tax reduction and provide evidence that the value to investors of a dollar of tax avoidance is a function of the method deriving it. Finally, my results are 
inconsistent with managers utilizing the compromised information environment to divert tax savings from opaque tax avoidance, adding to the debate on the valuation of tax avoidance in an agency context. 


\section{References}

Alexander, R. and Poe, J. 2011. Tax shelters, tax havens, and permanently reinvested earnings. Unpublished working paper. Electronic copy available at: http://ssrn.com/abstract=1822492

Accounting Principles Board (APB), 1972. “Accounting for Income Taxes - Special Areas" APB Opinion No. 23. New York, NY: APB.

Albring, S., Dzuranin, A. and Mills, L. 2005. Tax Savings on Repatriations for Foreign Earnings Under the American Jobs Creation Act of 2005. Tax Notes, August 82005.

Armstrong, C., Blouin, J., and Lacker, D. 2011. The incentives for tax planning. Journal of Accounting and Economics Forthcoming.

Ayers, B., Jiang, J., and Laplante, S. 2009. Taxable Income as a Performance Measure: The Effects of Tax Planning and Earnings Quality. Contemporary Accounting Research 26:1 15-54.

Ayers, B., Laplante, S. and Schwab, C. 2011. Does Tax Deferral Enhance Firm Value? Unpublished Working paper.

Babenko, I. and Tserlukevich, Y. 2009. Analyzing the Tax Benefits from Employee Stock Options. The Journal of Finance 64: 1797-1825.

Barth, M., 2000. Valuation-based accounting research: Implications for financial reporting and opportunities for future research. Accounting and Finance 40: 7-31.

Barth, M., Beaver, W. and Landsman, W., 2001. The relevance of the value relevance literature for financial accounting standard setting: another view. The Journal of Accounting and Economics 31: 77-104.

Barth, M., Cram, D., and Nelson, K., 2001. Accruals and the prediction of future cash flows. The Accounting Review 76 (1): 27-58.

Bauman, M. and Shaw, K.2005. Disclosure of Managers' Forecasts in Interim Financial Statements: A Study of Effective Tax Rate Changes. Journal of the American Taxation Association 27: 2 57-82.

Bauman, M. and Shaw, K.2008. The Usefulness of Disclosures of Untaxed Foreign Earnings in Firm Valuation. Journal of the American Taxation Association 30: 53-77.

Bebchuk, L., Cohen, A., and Ferrell, A. 2009. What Matters in Corporate Governance? The Review of Financial Studies 22:2 783-827.

Belsley, D., Kuh, E., Welsch, R. 1980. Regression diagnostics: Identifying Influential Data and Sources of Collinearity. John Wiley and Sons, Inc.

Blaylock, B., Shevlin, T. and Wilson, R. 2011. Tax Avoidance, Large Positive Temporary Book-Tax Differences and Earnings Persistence. The Accounting Review 87:1 91-121. 
Brown, J., Drake, K., Martin, M. 2011. Are Firms Myopic? The Case of Contracting on Performance and Uncertainty. Unpublished working paper Available at SSRN:

http://ssrn.com/abstract=1904932

Bryant-Kuetcher, L., Eiler, L. and Guenther, D. 2008. Taxes and Financial Assets: Valuing Permanently Reinvested Earnings. National Tax Journal 61: 699-720.

Chen, S., Chen, X., Cheng, Q., Shevlin, T., 2010. Are Family Firms More Tax Aggressive than NonFamily Firms? Journal of Financial Economics. 95: 41-61.

Cheng, C. S. A., Huang, H., Li, Y., Stanfield, J., 2011. The Effect of Hedge Fund Activism on Corporate Tax Avoidance. Unpublished working paper, Purdue University.

Collins, J., Hand, J. and Shackelford, D. 2000. Valuing Deferral: The Effect of Permanently Reinvested Foreign Earnings on Stock Prices. In International Taxation and Multinational Activity, edited by J. Hines. Chicago, IL: University of Chicago Press: 143-166.

Comprix, J., Mills, L., and Schmidt, A. 2011. Bias in Quarterly Estimates of Annual Effective Tax Rates and Earnings Management. Unpublished working paper Available at SSRN:

http://ssrn.com/abstract $=589425$

Desai, M., 2003. The Divergence between Book Income and Tax Income. Tax Policy and the Economy 17, 169-206.

Desai, M. and Dharmapala, D., 2009. Corporate Tax Avoidance and Firm Value. The Review of Economics and Statistics 91(3): 537-546.

De Simone, L., and Stomberg, B. 2011. Do investors incrementally value tax planning by income mobile firms? Unpublished working paper, University of Texas - Austin. Available at SSRN: http://dx.doi.org/10.2139/ssrn.1908967

Dey, A., 2008. Corporate Governance and Agency Conflicts. Journal of Accounting Research 46:5 $1143-1181$.

Dhaliwal, D. S., Huang, S. X., Moser, W., Pereira, R., 2011. Corporate Tax Avoidance and the Level and Valuation of Firm Cash Holdings. Unpublished working paper, University of Missouri Columbia.

Dittmar, A. and Mahrt-Smith, J. 2007. Corporate governance and the value of cash holdings. Journal of Financial Economics 83: 599-634.

Dyreng, S., Hanlon, M., Maydew, E., 2008. Long-Run Corporate Tax Avoidance. The Accounting Review. 83: 61-82.

Dyreng, S., Hanlon, M., Maydew, E., 2010. Effect of Executives on Corporate Tax Avoidance. The Accounting Review. 85: 1163-1189.

Dyreng, S. and Lindsey, B.P., 2009. Using Financial Accounting Data to Examine the Effect of Foreign Operations Located in Tax Havens and Other Countries on U.S. Multinational Firms' Tax Rates. The Journal of Accounting Research 47:5 1,283-1,316. 
Emerging Issues Task Force (FASB), 2000. Classification in the Statement of Cash Flows of the Income Tax Benefit Received by a Company upon Exercise of a Nonqualified Employee Stock Option. EITF 00-15. Norwalk, CT: FASB.

Financial Accounting Standards Board (FASB), 1992. Accounting for Income Taxes. Statement of Financial Accounting Standard 109. Norwalk, CT: FASB.

Financial Accounting Standards Board (FASB), 1995. Accounting for Stock-based Compensation. Statement of Financial Accounting Standard 123. Norwalk, CT: FASB.

Financial Accounting Standards Board (FASB), 2004. Share-based Payment. Statement of Financial Accounting Standard 123Revised. Norwalk, CT: FASB.

Gompers, P., Ishii, J., Metrick, A., 2003. Corporate Governance and Equity Prices. Quarterly Journal of Economics. 118: 107-156.

Foley, F., Hartzell, J., Titman, S. and Twite, G. 2007. Why do firms hold so much cash? A tax-based explanation. Journal of Financial Economics 86: 579-607.

Graham, J., Lang, M. and Shackelford, D. 2004. Employee Stock Options, Corporate Taxes and Debt Policy. Journal of Finance 59: 1585-1618.

Hanlon, M., and Heitzman, S. 2010. A review of tax research. Journal of Accounting and Economics 50: $127-178$.

Hanlon, M. Rajgopal, S. and Shevlin, T. 2003. Are executive stock options associated with future earnings? Journal of Accounting and Economics 36: 3-43.

Hanlon, M. and Shevlin, T. 2002. Accounting for Tax Benefits of Employee Stock Options and Implications for Research. Accounting Horizons 16: 1-16.

Hanlon, M., and Slemrod, J., 2009. What Does Tax Aggressiveness Signal? Evidence to News About Tax Shelter Involvement. Journal of Public Economics 93: 126-141.

Harford, J., Mansi, S., and Maxwell, W. 2008. Corporate Governance and firm cash holdings in the US. Journal of Financial Economics 87: 535-555.

Kahle, K. and Shastri, K. 2005. Firm Performance, Capital Structure, and the Tax Benefits of Employee Stock Options. The Journal of Financial and Quantitative Analysis 40: 135-160.

Key, K. 2008. Taxes and Asset Prices: The Case of Thoroughbreds. The Journal of the American Taxation Association 30:1 29-48.

Kim, J., Li, Y. and Zhang, L.. Corporate Tax Avoidance and Stock Price Crash Risk; Firm-Level Analysis. Journal of Financial Economics Forthcoming.

Koester, A. 2011. Investor Valuation of Tax Avoidance Through Uncertain Tax Positions. Unpublished Working Paper. Available at SSRN: http://ssrn.com/abstract=1905210

Krull, L. 2004. Permanently Reinvested Foreign Earnings, Taxes and Earnings Management. The Accounting Review 79: 3 745-767. 
Lisowsky, P, 2010. Seeking Shelter: Empirically Modeling Tax Shelters Using Financial Statement Information. The Accounting Review 85:5: 1693-1720.

Mehran, H. 1995. Executive Compensation Structure, ownership, and firm performance. Journal of Financial Economics 38: 163-184.

Montgomery, D., Peck, E. and Vining, G.. 2006. Introduction to Linear Regression Analysis. 4 th ed. John Wiley \& Sons, Inc.

Morck, R., Shleifer, A., and Vishny, R. 1988. Management ownership and corporate performance: An empirical analysis. Journal of Financial Economics 20: 293-315.

Myers, S.C., and R.G. Rajan. 1998. The paradox of liquidity. Quarterly Journal of Economics 108: 733771.

Petersen, M. 2009. Estimating Standard Errors in Finance Panel Data Sets: Comparing Approaches. The Review of Financial Studies 22: 435-480.

PricewaterhouceCoopers National Professional Services Group. 2007. Guide to Accounting for Income Taxes.

Raedy, J., Seidman, J. and Shackelford, D. 2011. Is there Information Content in the Tax Footnote? Unpublished working paper. Available at SSRN: $\underline{\text { http://ssrn.com/abstract=1759266 }}$

Rees, L. and Sivaramakrishnan. 2007. The effect of meeting or beating revenue forecasts on the association between quarterly returns and earnings forecast errors. Contemporary Accounting Research 24 (1): 259-290.

Robinson, J., Sikes, S. and Weaver, C. 2010. Performance measure of corporate tax departments. The Accounting Review 85:3 1035-1064.

United State Senate, Committee on Homeland Security and Government Affairs, Permanent Subcommittee on Investigations. The Role of Professional Firms in the U.S. Tax Shelter Industry. February 8, 2005.

Wilson, R., 2009. An Examination of Corporate Tax Shelter Participants. The Accounting Review 84: 969-999.

Wang, X. 2011. Tax Avoidance, Corporate Transparency and Firm Value. Unpublished working paper. Available at SSRN: http://ssrn.com/abstract=1904046

Zhao, Y. and Chen, K. 2008. Staggered Boards and Earnings Management. The Accounting Review 83:5 1347-1381. 
Appendix A: Variable Definitions

\begin{tabular}{|c|c|c|}
\hline$\underline{\text { Reference }}$ & $\underline{\text { Variable }}$ & $\begin{array}{l}\text { Description (source in parentheses, Compustat unless otherwise } \\
\text { noted) }\end{array}$ \\
\hline \multicolumn{3}{|c|}{ Hand Collected Variables and Tax Avoidance Measures } \\
\hline & CETR & $\begin{array}{l}\text { Cash Income Tax Paid (TXPD)/(Earnings before tax (PI)-Special Items } \\
\text { (SPI)) }\end{array}$ \\
\hline & CETR3 & $\begin{array}{l}\sum_{\mathrm{t}-2, \mathrm{t}}(\text { Cash Income Tax Paid (TXPD)/(Earnings before tax (PI)-Special } \\
\text { Items (SPI)) }\end{array}$ \\
\hline \multirow[t]{8}{*}{1} & CETR NO STOCK & $\begin{array}{l}\text { Adjusted CETR unrelated to stock option tax benefits = (Cash Income } \\
\text { Taxes Paid + Option Tax Benefit }) /(\text { Earnings before tax }- \text { Special Items } \\
+ \text { 123R Option Expense })\end{array}$ \\
\hline & STOCK AVOID & $\begin{array}{l}\text { Tax Avoidance related to stock option tax benefits = Option Tax } \\
\text { Benefit/(Earnings before tax }- \text { Special Items }+123 \mathrm{R} \text { Option Expense) }\end{array}$ \\
\hline & Option Tax Benefit & $\begin{array}{l}\text { Option Tax Benefit - Reported, if missing use Option Tax Benefit - } \\
\text { Estimated. }\end{array}$ \\
\hline & $\begin{array}{l}\text { Option Tax Benefit: } \\
\text { Reported }\end{array}$ & $\begin{array}{l}\text { Reported cash tax benefit from stock option deductions. (Hand } \\
\text { collected from statement of cash flows, statement of equity, share-based } \\
\text { compensation footnote or tax footnote.) }\end{array}$ \\
\hline & $\begin{array}{l}\text { Option Tax Benefit: } \\
\text { Estimated }\end{array}$ & $\begin{array}{l}\text { number of options exercised(OPTEXD)*(weighted average exercise } \\
\text { price of new grants during the year (OPTPRCGR) less the weighted } \\
\text { average exercise price of options exercised during the } \\
\text { year(OPTPRCEX). (Hand collected prior to 2004.) }\end{array}$ \\
\hline & $\begin{array}{l}\text { 123R Option } \\
\text { Expense }\end{array}$ & $\begin{array}{l}\text { 123R Option Expense - Reported, if missing, use 123R Option } \\
\text { Expense - Estimated. }\end{array}$ \\
\hline & $\begin{array}{l}\text { 123R Option } \\
\text { Expense: Reported }\end{array}$ & $\begin{array}{l}\text { Stock option compensation expense reported in share-based } \\
\text { compensation footnote. }\end{array}$ \\
\hline & $\begin{array}{l}\text { 123R Option } \\
\text { Expense: Estimated }\end{array}$ & $\begin{array}{l}\text { Prior year's disclosed unrecognized option expense divided by the } \\
\text { disclosed vesting period for the options. (Hand collected from share- } \\
\text { based compensation footnote) }\end{array}$ \\
\hline \multirow[t]{3}{*}{2} & CETR NO DEPR & $\begin{array}{l}\text { Adjusted CETR unrelated to accelerated tax depreciation }=(\text { Cash } \\
\text { Income Taxes Paid }+\Delta \text { DTL PPE }) /(\text { Earnings before tax }- \text { Special } \\
\text { Items })\end{array}$ \\
\hline & DEPR AVOID & $\begin{array}{l}\text { Tax Avoidance related to accelerated tax depreciation }=\Delta \mathrm{DTL} \\
\mathrm{PPE} /(\text { Earnings before tax }- \text { Special Items) }\end{array}$ \\
\hline & DTL PPE & $\begin{array}{l}\text { Deferred tax liability for property plant and equipment. (Hand collected } \\
\text { from tax footnote.) }\end{array}$ \\
\hline \multirow[t]{3}{*}{ 3a } & $\begin{array}{l}\text { CETR NO } \\
\text { PRETAX } \\
\text { DISCLOSED }\end{array}$ & $\begin{array}{l}\text { Adjusted CETR unrelated to permanent residual tax deferral }- \text { disclosed } \\
=(\text { Cash Income Taxes Paid }+\Delta \text { PRE TAX Disclosed }) /(\text { Earnings before } \\
\text { tax }- \text { Special Items })\end{array}$ \\
\hline & $\begin{array}{l}\text { PRETAX } \\
\text { DISCLOSED } \\
\text { AVOID } \\
\end{array}$ & $\begin{array}{l}\text { Tax avoidance related to permanent residual tax deferral }- \text { disclosed }= \\
\Delta \text { PRE TAX Disclosed/(Earnings before tax }- \text { Special Items })\end{array}$ \\
\hline & PRETAX Disclosed & $\begin{array}{l}\text { Disclosed unrecognized tax liability on unremitted foreign earnings. } \\
\text { (Hand collected from tax footnote.) }\end{array}$ \\
\hline \multirow[t]{2}{*}{$3 \mathbf{b}$} & $\begin{array}{l}\text { CETR NO } \\
\text { PRETAX } \\
\text { ESTIMATE }\end{array}$ & $\begin{array}{l}\text { Adjusted CETR unrelated to permanent residual tax deferral }- \\
\text { estimated }=(\text { Cash Income Taxes Paid }+\Delta \text { PRE TAX } \\
\text { Estimated }) /(\text { Earnings before tax }- \text { Special Items })\end{array}$ \\
\hline & $\begin{array}{l}\text { PRE TAX } \\
\text { ESTIMATE }\end{array}$ & $\begin{array}{l}\text { Tax avoidance related to permanent residual tax deferral }- \text { estimated }= \\
\Delta \text { PRE TAX Estimated/(Earnings before tax }- \text { Special Items })\end{array}$ \\
\hline
\end{tabular}




\begin{tabular}{|c|c|c|}
\hline & AVOID & \\
\hline & $\begin{array}{l}\text { PRETAX } \\
\text { Estimated: Bauman } \\
\text { and Shaw }\end{array}$ & $(\Delta \mathrm{PRE} /(1-\mathrm{FETR} 3)) *(35 \%-\mathrm{FETR} 3)$ \\
\hline & $\begin{array}{l}\text { PRETAX } \\
\text { Estimated: } \\
\text { Krull }\end{array}$ & $\triangle \mathrm{PRE} *(35 \%$-FETR5) \\
\hline & PRE & Permanently Reinvested Earnings. (Hand collected from tax footnote.) \\
\hline & FETR3 & $\begin{array}{l}\text { Current foreign tax expense (TXFO)/Pre-tax foreign income (PIFO) } \\
\text { summed from } \mathrm{t}-3 \text { to } \mathrm{t}-1\end{array}$ \\
\hline & FETR5 & $\begin{array}{l}\text { Current foreign tax expense (TXFO)/Pre-tax foreign income (PIFO) } \\
\text { summed from t-5 to t-1. Requires } 3 \text { years of data. }\end{array}$ \\
\hline $3 \mathbf{c}$ & $\begin{array}{l}\text { CETR NO } \\
\text { PROVIDE }\end{array}$ & $\begin{array}{l}\text { Adjusted CETR unrelated to provision for residual tax }=(\text { Cash Income } \\
\text { Taxes Paid }+\Delta \text { DTL FOR }) /(\text { Earnings before tax }- \text { Special Items })\end{array}$ \\
\hline & PROVDE AVOID & $\begin{array}{l}\text { Tax avoidance related to provision for residual tax }=\Delta \mathrm{DTL} \\
\text { FOR/(Earnings before tax }- \text { Special Items) }\end{array}$ \\
\hline & DTL FOR & $\begin{array}{l}\text { Deferred tax liability for unremitted foreign earnings. (Hand collected } \\
\text { from tax footnote.) }\end{array}$ \\
\hline 3d & $\begin{array}{l}\text { CETR NO } \\
\text { RESIDUAL }\end{array}$ & $\begin{array}{l}\text { Adjusted CETR Unrelated to residual tax deferral }=(\text { Cash Income } \\
\text { Taxes Paid }+\Delta \text { PRETAX }+\Delta \text { DTL FOR }) /(\text { Earnings before tax }- \\
\text { Special Items })\end{array}$ \\
\hline & RESIDUAL AVOID & $\begin{array}{l}\text { Tax Avoidance related to residual tax deferral }=(\Delta \text { PRETAX }+\Delta \text { DTL } \\
\text { FOR }) /(\text { Earnings before tax }- \text { Special Items })\end{array}$ \\
\hline 4 & Adjusted CETR & $\begin{array}{l}\text { (Cash Income Taxes Paid }+ \text { Option Tax Benefit }+\Delta \text { DTL PPE }+\Delta \\
\text { PRETAX }+\Delta \text { DTL FOR }) /(\text { Earnings before tax }- \text { Special Items }+123 R \\
\text { Option Expense) }\end{array}$ \\
\hline $5 \mathbf{a}$ & CETR AVOID & Statutory - Unadjusted CETR $=35 \%$ - CETR \\
\hline $5 \mathbf{b}$ & OTHER AVOID & Statutory Rate - Adjusted CETR $=35 \%$ - Adjusted CETR \\
\hline $5 \mathbf{c}$ & SPECIFIC AVOID & STOCK AVOID + DEPR AVOID + RESIDUAL AVOID \\
\hline $\begin{array}{l}\text { Reduced } \\
\text { Models }\end{array}$ & $\begin{array}{l}\text { CETR NO STOCK } \\
\text { AVOID }\end{array}$ & CETR AVOID - STOCK AVOID \\
\hline & $\begin{array}{l}\text { CETR NO DEPR } \\
\text { AVOID }\end{array}$ & CETR AVOID - DEPR AVOID \\
\hline & $\begin{array}{l}\text { CETR NO } \\
\text { RESIDUAL AVOID }\end{array}$ & CETR AVOID - RESIDUAL AVOID \\
\hline Dependent & nd Control Variables & \\
\hline $\begin{array}{l}\text { Dependent } \\
\text { Variable }\end{array}$ & $\begin{array}{l}\text { Firm Value } \\
\text { (Tobin's Q) }\end{array}$ & $\begin{array}{l}\text { Ratio of market value of firm to book value of firm }= \\
\left((\mathrm{AT})+\left(\left(\mathrm{PRCC} \_\mathrm{C}\right) *(\mathrm{CSHO})\right)-(\mathrm{CEQ})\right) /(\mathrm{AT})\end{array}$ \\
\hline $\begin{array}{l}\text { Control } \\
\text { Variables }\end{array}$ & Stock Options & $\begin{array}{l}\text { Average annual value realized from the exercise of options for the top } \\
\text { five executives of options by the top five executives grossed up by the } \\
\text { fraction of options owned by the covered executives in year t- } 1 \\
\text { (Execucomp) }\end{array}$ \\
\hline & PPE & $\left(\mathrm{PPEGT} / \mathrm{AT}_{\mathrm{t}-1}\right)$ \\
\hline & Foreign Income & $\left(\mathrm{PIFO} / \mathrm{AT}_{\mathrm{t}-1}\right)$ \\
\hline & Size & Sales (SALE) \\
\hline & Risk & $\begin{array}{l}\text { Standard deviation of monthly stock returns over previous } 36 \text { months } \\
\text { (CRSP) }\end{array}$ \\
\hline & Growth & $\begin{array}{l}3 \text { year average sales growth from } \mathrm{t}-2 \text { to } \mathrm{t}= \\
\sum_{\mathrm{t}-2, \mathrm{t}}\left(\mathrm{SALE}_{\mathrm{t}}-\mathrm{SALE}_{\mathrm{t}-1}\right) / \mathrm{SALE}_{\mathrm{t}-1}\end{array}$ \\
\hline
\end{tabular}




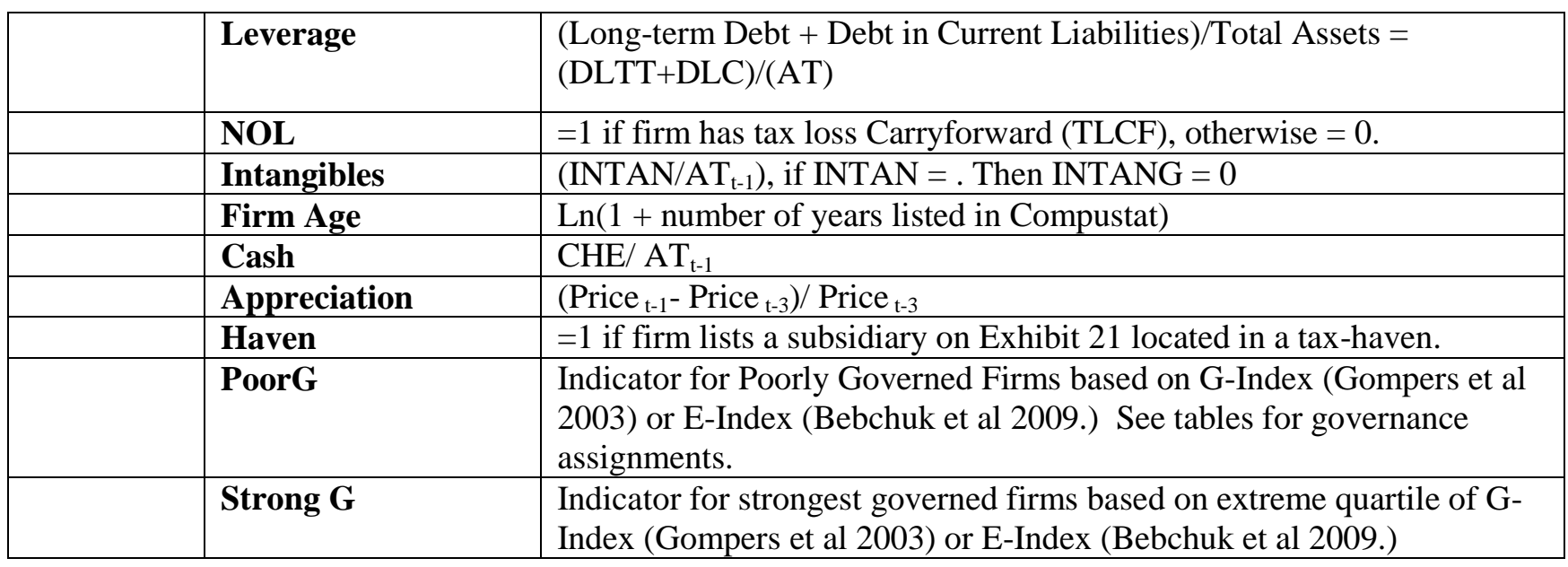




\section{Appendix B: Sample Selection}

\begin{tabular}{|c|c|}
\hline 2005 Fortune 500 firm year observations (1998-2010) & 7,000 \\
\hline $\begin{array}{l}44 \text { firms excluded from sample } \\
\text { (LP, Private Company, Mutual Insurance Company, Non-profit) }\end{array}$ & (616) \\
\hline Firm year observations not spanning 10 year period & $(298)$ \\
\hline Firm year observations missing $10-\mathrm{K}$ & $(230)$ \\
\hline Firm year observations excluded due to bankruptcy filing & $(27)$ \\
\hline Missing total assets in Compustat & $(16)$ \\
\hline Hand collected observations & 5,813 \\
\hline \multicolumn{2}{|c|}{1 year Cash Effective Tax Rate (CETR) Regression Analysis Sample Reduction } \\
\hline 1997 firm year observations (lag year required) & $(338)$ \\
\hline CETR greater than 1 & $(92)$ \\
\hline CETR less than 0 & $(425)$ \\
\hline Post 123R observations missing stock option compensation expense & $(603)$ \\
\hline Reports “Amount not disclosed” for PRE & (194) \\
\hline Missing control variables (CRSP, Execucomp, Risk Metrics) & $(888)$ \\
\hline CETR sample & 3,273 \\
\hline \multicolumn{2}{|l|}{3 year Cash Effective Tax Rate (CETR3) Analysis Sample Reduction } \\
\hline 1997-1999 firm year observations (3 year lag requirement) & $(1,048)$ \\
\hline CETR3 greater than 1 & $(58)$ \\
\hline CETR3 less than 0 & $(240)$ \\
\hline Post 123R observations missing stock option compensation expense & $(810)$ \\
\hline Reports “Amount not disclosed" for PRE & $(168)$ \\
\hline Missing control variables (CRSP, Execucomp, Risk Metrics) & $(877)$ \\
\hline CETR3 sample & 2,612 \\
\hline
\end{tabular}




\section{Appendix C: Tax Haven Country Listing}

\begin{tabular}{|c|c|}
\hline Andorra & Lebanon \\
\hline Anguilla & Liberia \\
\hline Antigua and Barbuda & Liechtenstein \\
\hline Aruba & Luxembourg \\
\hline Bahamas & Macao \\
\hline Bahrain & Macau \\
\hline Barbados & Maldives \\
\hline Belize & Malta \\
\hline Bermuda & Marshall Islands \\
\hline Botswana & Mauritius \\
\hline British Virgin Islands & Monaco \\
\hline Brunei Darussalam & Montserrat \\
\hline Cape Verde & Nauru \\
\hline Cayman Islands & Netherlands Antilles \\
\hline Cook Islands & Niue \\
\hline Costa Rica & Palau \\
\hline Cyprus & Panama \\
\hline Dominica & Samoa \\
\hline Gibraltar & San Marino \\
\hline Grenada & Seychelles \\
\hline Guernsey and Alderney & Singapore \\
\hline Hong Kong & St. Lucia \\
\hline Ireland & St. Vincent and the Grenadines \\
\hline Isle of Man & Switzerland \\
\hline Jersey & U.S. Virgin Islands \\
\hline Jordan & Uruguay \\
\hline Kitts and Nevis & Vanuatu \\
\hline
\end{tabular}

Tax haven country identification follows Dyreng and Lindsey (2009). Countries identified as tax havens by three of the four following sources: (1) Organization for Economic Cooperation and Development (OECD), (2) the U.S. Stop Tax Havens Abuse Act, (3) The International Monetary Fund (IMF), and (4) the Tax Research Organization. 


\section{Appendix D: Illustration of Tax Avoidance Adjustments}

\begin{tabular}{|c|c|}
\hline Variables: & \\
\hline Earnings before tax (no special items) & 100 \\
\hline Cash Taxes Paid & 20 \\
\hline Cash Tax Benefit of Stock Options & 5 \\
\hline Stock Option Compensation Expense & 0 \\
\hline$\Delta$ DTL on Property, Plant and Equipment (DTL PPE Increase) & 2 \\
\hline$\Delta$ Unrecognized tax liability on foreign earnings (PRETAX Increase) & 3 \\
\hline$\Delta$ DTL on Unremitted foreign earnings (DTL FE Increase) & 1 \\
\hline \multicolumn{2}{|l|}{ Tax Avoidance Measures: } \\
\hline Unadjusted CETR $=$ Cash Taxes Paid/Earnings before tax & $20 \%$ \\
\hline CETR AVOID $=35 \%$ - Unadjusted CETR & $15 \%$ \\
\hline $\begin{array}{l}\text { Adjusted CETR }= \\
(\text { Cash Taxes Paid }+ \text { Cash Tax Benefit of Stock Options }+\Delta \text { DTL PPE }+\Delta \text { PRETAX }+ \\
\Delta \text { DTL FE }) /(\text { Earnings before tax }+ \text { Stock Compensation Expense })\end{array}$ & $31 \%$ \\
\hline OTHER AVOID = 35\% - Adjusted CETR & $4 \%$ \\
\hline $\begin{array}{l}\text { SPECIFIC AVOID= Adjusted CETR - Unadjusted CETR (or CETR AVOID - } \\
\text { OTHER AVOID) }\end{array}$ & $11 \%$ \\
\hline $\begin{array}{l}\text { STOCK AVOID }= \\
\text { Stock Option Tax/PI or }(\text { TXPD + Stock Option Tax }) /(\mathrm{PI})-\text { Unadjusted CETR }\end{array}$ & $5 \%$ \\
\hline $\begin{array}{l}\text { DEPR AVOID }= \\
\Delta \text { DTL PPE } /(\mathrm{PI}) \text { or }(\mathrm{TXPD}+\Delta \mathrm{DTL} \text { PPE }) /(\mathrm{PI})-\text { Unadjusted CETR }\end{array}$ & $2 \%$ \\
\hline $\begin{array}{l}\text { RESIDUAL AVOID }= \\
(\Delta \text { PRETAX }+\Delta \text { DTL FOR }) /(\mathrm{PI}) \text { or }(\mathrm{TXPD}+\Delta \mathrm{PRETAX}+\Delta \mathrm{DTL} \text { FOR }) /(\mathrm{PI})- \\
\text { Unadjusted CETR }\end{array}$ & $4 \%$ \\
\hline SPPECIFIC AVOID = Stock Benefit Tax Avoid + PPE Tax Avoid + Defer Tax Avo & $11 \%$ \\
\hline
\end{tabular}

*Additional examples, including journal entries, illustration of adjustments for fictitious company over 2 periods and adjustments for real companies available from the author. 


\begin{tabular}{|c|c|c|c|c|c|c|c|}
\hline \multicolumn{8}{|c|}{ Table 1 } \\
\hline \multicolumn{8}{|c|}{ Descriptive Statistics } \\
\hline \multicolumn{8}{|c|}{ Panel A: Descriptive Statistics for Hand Collected and Estimated Variables } \\
\hline Variable & $\mathrm{n}^{\mathrm{a}}$ & $\%$ Report & Mean & Std. Dev & 25 th & Median & 75 th \\
\hline Option Tax Benefit: Reported & 2081 & $35.8 \%$ & 60.027 & 198.43 & 4.000 & 15.896 & 45.831 \\
\hline Option Tax Benefit: Estimate & 5106 & $87.8 \%$ & 31.216 & 110.577 & 0.49 & 5.543 & 22.302 \\
\hline Option Tax Benefit & 5813 & $100.0 \%$ & 36.155 & 141.708 & 0.4696 & 6.0 & 26 \\
\hline 123R Option Expense: Reported & 1200 & $58.9 \%$ & 38.214 & 85.97 & 3.7 & 13.05 & 36.05 \\
\hline 123R Option Expense: Estimate & 542 & $26.6 \%$ & 35.23 & 120.144 & 5.6 & 15.619 & 27.49 \\
\hline 123R Option Expense & 1507 & $74.0 \%$ & 40.276 & 93.988 & 4.0 & 13.68 & 34 \\
\hline DTL PPE & 5163 & $88.8 \%$ & -760.681 & 2055.276 & -661 & -163.4 & -31 \\
\hline PRE & 2946 & $50.7 \%$ & 2445.099 & 5950.905 & 149 & 665.809 & 2000 \\
\hline PRETAX disclosed & 642 & $11.0 \%$ & 354.253 & 841.203 & 2.07 & 55 & 248.7 \\
\hline PRETAX: estimate (Bauman and Shaw) & 2382 & $41.0 \%$ & 488.61 & 1394.62 & 0.068 & 79.007 & 356.24 \\
\hline PRETAX: estimate (Krull) & 2382 & $41.0 \%$ & 298.454 & 973.656 & 0.0 & 19.4621 & 183.2506 \\
\hline PRETAX & 2560 & $44.0 \%$ & 326.756 & 984.979 & 0 & 31.697 & 211.778 \\
\hline FETR (3 year) & 4156 & $71.5 \%$ & $25.5 \%$ & 0.288 & $0.00 \%$ & $19.70 \%$ & $31.60 \%$ \\
\hline FETR (5 year) & 4156 & $71.5 \%$ & $29.2 \%$ & 0.294 & $0.00 \%$ & $25.60 \%$ & $39.00 \%$ \\
\hline DTL FOR & 2515 & $43.3 \%$ & -68.361 & 463.018 & -4.0 & 0.0 & 0.0 \\
\hline$\Delta \mathrm{PRE}$ & 5813 & $100.0 \%$ & 168.56 & 1154.241 & 0.0 & 0.0 & 58.7 \\
\hline$\Delta$ PRE TAX: Reported & 5813 & $100.0 \%$ & 8.182 & 103.94 & 0.0 & 0.0 & 0.0 \\
\hline$\triangle$ PRE TAX: Estimate (Bauman and Shaw) & 5813 & $100.0 \%$ & 31.097 & 0.0 & 0.0 & 0.0 & 0.0 \\
\hline$\triangle$ PRE TAX: Estimate (Krull) & 5813 & $100.0 \%$ & 20.4 & 165.39 & 0.0 & 0.0 & 0.0 \\
\hline$\triangle$ DTL FOR & 5813 & $100.0 \%$ & -5.774 & 109.785 & 0.0 & 0.0 & 0.0 \\
\hline$\triangle$ DTL PPE & 5813 & $100.0 \%$ & -52.332 & 732.228 & -36.338 & -2.4105 & 6.719 \\
\hline Haven & 5813 & $100.0 \%$ & 0.438 & 0.438 & 0 & 0 & 1 \\
\hline Unique Country & 2547 & $43.8 \%$ & 5.217 & 4.381 & 2 & 4 & 7 \\
\hline Total Haven & 2547 & $43.8 \%$ & 20.513 & 37.162 & 1 & 9 & 22 \\
\hline \multicolumn{8}{|c|}{ 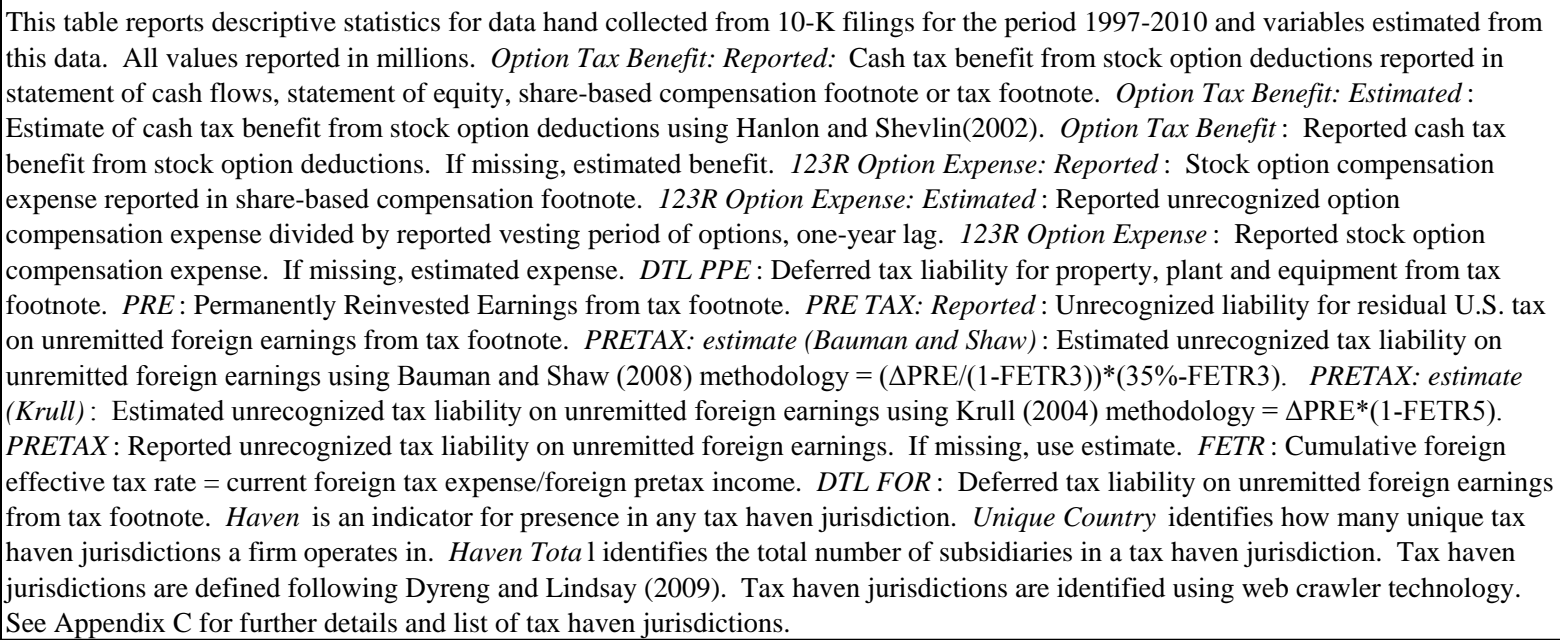 } \\
\hline $\begin{array}{l}\text { a Level statistics are reported for firm year ol } \\
\text { values are set to zero for change variables u } \\
\text { material amount of that variable. \% Report } \\
\text { observations with the necessary data to estir }\end{array}$ & $\begin{array}{l}\text { ns repo } \\
\text { erwise } \\
\text { ercentas } \\
\text { variable }\end{array}$ & $\begin{array}{l}\text { ing the var } \\
\text { ted becaus } \\
\text { of firm yes }\end{array}$ & $\begin{array}{l}\text { firms and cha } \\
\text { observatio }\end{array}$ & $\begin{array}{l}\text { not report } \\
\text { disclosing }\end{array}$ & mount a & $\begin{array}{l}\text { ervations. } \\
\text { ssumed } n \\
\text { he percen }\end{array}$ & $\begin{array}{l}\text { issing } \\
\text { lo have a } \\
\text { e of }\end{array}$ \\
\hline
\end{tabular}


Table 1

Descriptive Statistics

Panel B: Correlation Coefficients for Hand Collected Data

\begin{tabular}{|lccccc|}
\hline \hline & PRE & PRETAX & Option Tax Benefit & DTL PPE & DTL FOR \\
\hline PRE & 1.000 & $\mathbf{0 . 6 2 4}$ & $\mathbf{0 . 3 1 7}$ & $\mathbf{- 0 . 2 4 3}$ & -0.015 \\
PRETAX & $\mathbf{0 . 8 1 3}$ & 1.000 & $\mathbf{0 . 2 8 6}$ & $\mathbf{- 0 . 1 2 4}$ & 0.002 \\
Option Tax Benefit & $\mathbf{0 . 1 2 1}$ & $\mathbf{0 . 0 8 7}$ & 1.000 & $\mathbf{- 0 . 0 3 9}$ & $\mathbf{- 0 . 0 4 8}$ \\
DTL PPE & $\mathbf{- 0 . 3 1 5}$ & -0.008 & $\mathbf{- 0 . 0 2 7}$ & 1.000 & $\mathbf{- 0 . 0 6 6}$ \\
DTL FOR & $\mathbf{- 0 . 2 9 7}$ & $\mathbf{- 0 . 2 9 4}$ & $\mathbf{- 0 . 1 5 8}$ & 0.013 & 1.000 \\
\hline
\end{tabular}

Panel B presents Spearman (upper panel) and Pearson (lower panel) correlation coefficients for hand-collected data. Correlations significant at $\mathrm{p}<.05$ in bold. See Appendix A or Panel A for variable description. 
Table 1

Descriptive Statistics

Panel C: Descriptive Statistics for Tax Avoidance Measures and Proposed Adjustments

\begin{tabular}{|c|c|c|c|c|c|c|}
\hline Tax Avoidance Measures & $\mathrm{n}$ & Mean & Std. Dev & 25 th & Median & 75th \\
\hline CETR & 3273 & $24.66 \%$ & 0.155 & $14.15 \%$ & $24.31 \%$ & $32.93 \%$ \\
\hline CETR AVOID & 3273 & $10.34 \%$ & 0.155 & $2.07 \%$ & $10.69 \%$ & $20.85 \%$ \\
\hline STOCK AVOID & 3273 & $2.19 \%$ & 0.0544 & $0.10 \%$ & $0.90 \%$ & $0.00 \%$ \\
\hline DEPR AVOID & 3273 & $3.32 \%$ & 0.316 & $-0.58 \%$ & $0.50 \%$ & $4.14 \%$ \\
\hline RESIDUAL AVOID (Bauman and Shaw) & 3273 & $1.62 \%$ & 0.085 & $0.00 \%$ & $0.00 \%$ & $1.32 \%$ \\
\hline RESIDUAL AVOID (Krull) & 3273 & $1.14 \%$ & 0.011 & $0.00 \%$ & $0.00 \%$ & $0.58 \%$ \\
\hline OTHER AVOID & 3273 & $3.58 \%$ & 0.393 & $-4.20 \%$ & $4.39 \%$ & $15.43 \%$ \\
\hline CETR3 & 2612 & $24.51 \%$ & 0.1416 & $15.61 \%$ & $23.98 \%$ & $32.00 \%$ \\
\hline CETR AVOID3 & 2612 & $10.49 \%$ & 0.1416 & $2.99 \%$ & $11.02 \%$ & $19.39 \%$ \\
\hline STOCK AVOID3 & 2612 & $2.51 \%$ & 0.061 & $0.3 \%$ & $1.1 \%$ & $2.7 \%$ \\
\hline DEPR AVOID3 & 2612 & $3.5 \%$ & 0.1909 & $-0.27 \%$ & $0.66 \%$ & $4.33 \%$ \\
\hline RESIDUAL AVOID3 (Bauman and Shaw) & 2612 & $1.08 \%$ & 0.046 & $0.00 \%$ & $0.00 \%$ & $0.69 \%$ \\
\hline RESIDUAL AVOID3 (Krull) & 2612 & $1.08 \%$ & 0.011 & $0.00 \%$ & $0.00 \%$ & $0.69 \%$ \\
\hline OTHER AVOID3 & 2612 & $3.57 \%$ & 0.238 & $-3.10 \%$ & $4.36 \%$ & $13.49 \%$ \\
\hline
\end{tabular}

Panel B presents descriptive statistics for tax avoidance measures and proposed adjustments. See Appendix A for variable descriptions. CETR: Cash Taxes Paid/Earnings before tax and special items. CETR AVOID : 35\%-CETR. STOCK AVOID: Tax avoidance resulting from stock option tax benefits = Option Tax Benefit/Earnings before tax and special items. DEPR AVOID: Tax avoidance resulting from accelerated tax depreciation deductions $=\triangle \mathrm{DTL}$ PPE/Earnings before tax and special items. RESIDUAL AVOID: Tax avoidance resulting from deferral of residual U.S. tax on foreign income $=(\triangle$ PRETAX $+\triangle \mathrm{DTL}$ unremitted foreign earnings $) /$ Earnings before tax and special items. OTHER AVOID : Tax avoidance unrelated to specific methods of tax avoidance $=35 \%$-adjusted CETR. Variables ending in " 3 " are cumulative threeyear measures. Sample period CETR 1998-2010, CETR3 2000-2010. See Appendix B for sample selection. 
Table 2A

Test of Adjusted Tax Avoidance Measures Relation to Traditional Control Variables using CETR3

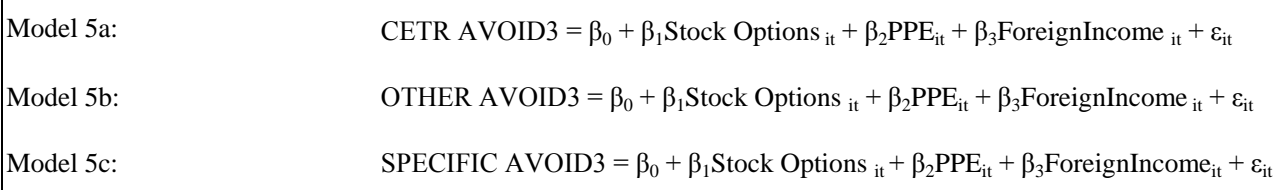

Panel A: Complete Model

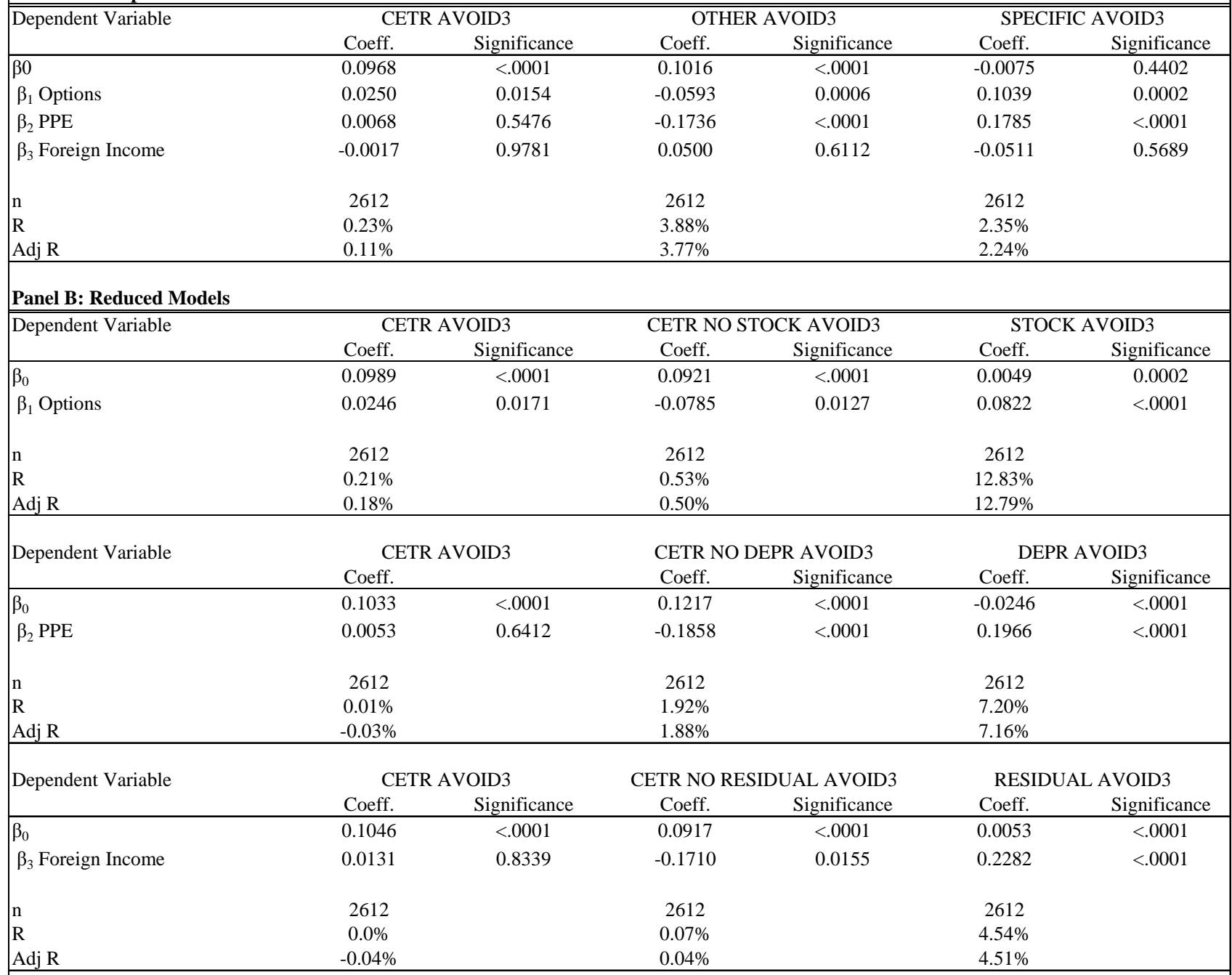

This table presents results of a regression of the unadjusted and adjusted tax avoidance measure on variables utilized in prior research to control for a firm's ability to reduce tax burden, specifically option compensation, property, plant, and equipment, and foreign earnings. See Appendix A and prior panels for variable description. Control variables defined as follows. Options: Average annual value realized from the exercise of options for the top five executives of options by the top five executives grossed up by the fraction of options owned by the covered executives in year $\mathrm{t}-1$ (Execucomp). $P P E$ : Property, plant and equipment, gross $=\left(\mathrm{PPEGT} / \mathrm{AT}_{\mathrm{t}-1}\right)$. Foreign Income $:$ Pre-tax income from foreign operations $=(\mathrm{PIFO} / \mathrm{AT} \mathrm{t}-1)$. Panel A includes dependent variables CETR AVOID3: 35\% - unadjusted CETR3; OTHER AVOID3 : tax avoidance unrelated to stock option tax benefits, accelerated tax depreciation and residual tax deferral $=35 \%$ - adjusted CETR3 and SPECIFIC AVOID3: tax avoidance related to stock option tax benefits, accelerated tax depreciation and residual tax deferral. Panel B includes dependent variables CETR AVOID3, CETR NO STOCK AVOID3 : tax avoidance implied by CETR3 unrelated to stock option tax benefits, STOCK AVOID3: tax avoidance from stock option tax benefits, CETR NO DEPR AVOID3 : tax avoidance implied by the CETR3 unrelated to accelerated tax depreciation deductions, DEPR AVOID3: tax avoidance related to accelerated tax depreciation deductions, CETR NO RESIDUAL AVOID3 : tax avoidance implied by the CETR3 unrelated to deferral of residual U.S. tax on foreign earnings and RESIDUAL AVOID3 : tax avoidance related to deferral of residual U.S. tax on foreign earnings. 
Table 2B

Test of Adjusted Tax Avoidance Measures Relation to Traditional Control Variables using CETR

\begin{tabular}{|c|c|c|c|c|c|c|}
\hline Model 5a: & \multicolumn{6}{|c|}{ CETR AVOID $_{\text {it }}=\beta_{0}+\beta_{1}$ Stock Options $_{\text {it }}+\beta_{2}$ PPE $_{\text {it }}+\beta_{3}$ ForeignIncome $_{\text {it }}+\varepsilon_{\text {it }}$} \\
\hline Model 5b: & \multicolumn{6}{|c|}{ OTHER AVOID $_{\text {it }}=\beta_{0}+\beta_{1}$ Stock Options $_{\text {it }}+\beta_{2}$ PPE $_{\text {it }}+\beta_{3}$ ForeignIncome $_{\text {it }}+\varepsilon_{\text {it }}$} \\
\hline Model 5c: & \multicolumn{6}{|c|}{ SPECIFIC AVOID $_{\text {it }}=\beta_{0}+\beta_{1}$ Stock Options $_{\text {it }}+\beta_{2} \mathrm{PPE}_{\text {it }}+\beta_{3}$ ForeignIncome $_{\text {it }}+\varepsilon_{\text {it }}$} \\
\hline \multicolumn{7}{|c|}{ Panel A: Complete Model } \\
\hline \multirow{2}{*}{ Dependent Variable } & \multicolumn{2}{|c|}{ CETR AVOID } & \multicolumn{2}{|c|}{ OTHER AVOID } & \multicolumn{2}{|c|}{ SPECIFIC AVOID } \\
\hline & Coeff. & Significance & Coeff. & Significance & Coeff. & Significance \\
\hline$\beta_{0}$ & 0.0985 & $<.0001$ & 0.1310 & $<.0001$ & -0.0430 & 0.0100 \\
\hline$\beta_{1}$ Options & -0.0011 & 0.1448 & -0.0369 & 0.0924 & 0.0673 & 0.0213 \\
\hline$\beta_{2} \mathrm{PPE}$ & 0.0147 & 0.9241 & -0.2747 & $<.0001$ & 0.2932 & $<.0001$ \\
\hline$\beta_{3}$ Foreign Income & 0.0589 & 0.2757 & -0.0113 & 0.9086 & 0.0607 & 0.6163 \\
\hline $\mathrm{n}$ & 3273 & & 3273 & & 3273 & \\
\hline $\mathrm{R}$ & $0.10 \%$ & & $3.63 \%$ & & $2.36 \%$ & \\
\hline Adj R & $0.01 \%$ & & $3.54 \%$ & & $2.27 \%$ & \\
\hline \multicolumn{7}{|c|}{ Panel B: Reduced Models } \\
\hline \multirow[t]{2}{*}{ Dependent Variable } & \multicolumn{2}{|c|}{ CETR AVOID } & \multicolumn{2}{|c|}{ 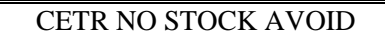 } & \multicolumn{2}{|c|}{ STOCK AVOID } \\
\hline & Coeff. & Significance & Coeff. & Significance & Coeff. & Significance \\
\hline$\beta_{0}$ & 0.0993 & $<.0001$ & 0.0901 & $<.0001$ & 0.0072 & $<.0001$ \\
\hline$\beta_{1}$ Options & 0.0158 & 0.1148 & -0.0394 & 0.0004 & 0.0572 & $<.0001$ \\
\hline$n$ & 3273 & & 3273 & & 3273 & \\
\hline $\mathrm{R}$ & $0.08 \%$ & & $0.40 \%$ & & $8.00 \%$ & \\
\hline Adj R & $0.04 \%$ & & $0.37 \%$ & & $7.97 \%$ & \\
\hline \multirow[t]{2}{*}{ Dependent Variable } & & \multicolumn{2}{|c|}{ CETR NO DEPR AVOID } & \multicolumn{2}{|c|}{ DEPR AVOID } \\
\hline & \multicolumn{2}{|c|}{$\begin{array}{l}\text { CETR AVOID } \\
\text { Coeff. }\end{array}$} & Coeff. & Significance & Coeff. & Significance \\
\hline$\beta_{0}$ & 0.1040 & $<.0001$ & 0.1638 & $<.0001$ & -0.0529 & $<.0001$ \\
\hline$\beta_{2}$ PPE & -0.0020 & 0.8583 & -0.2997 & $<.0001$ & 0.2765 & $<.0001$ \\
\hline $\mathrm{n}$ & 3273 & & 3273 & & 3273 & \\
\hline $\mathrm{R}$ & $0.00 \%$ & & $2.49 \%$ & & $5.70 \%$ & \\
\hline Adj R & $-0.03 \%$ & & $2.46 \%$ & & $5.67 \%$ & \\
\hline \multirow[t]{2}{*}{ Dependent Variable } & \multicolumn{2}{|c|}{ CETR AVOID } & \multicolumn{2}{|c|}{ CETR NO RESIDUAL AVOID } & \multicolumn{2}{|c|}{ RESIDUAL AVOID } \\
\hline & Coeff. & Significance & Coeff. & Significance & Coeff. & Significance \\
\hline$\beta_{0}$ & 0.1017 & $<.0001$ & 0.0961 & $<.0001$ & 0.0034 & 0.0055 \\
\hline$\beta_{3}$ Foreign Income & 0.0693 & 0.2023 & -0.2393 & $<.0001$ & 0.3245 & $<.0001$ \\
\hline $\mathrm{n}$ & 3273 & & 3273 & & 3273 & \\
\hline $\mathrm{R}$ & $0.04 \%$ & & $0.25 \%$ & & $3.26 \%$ & \\
\hline Adj R & $0.01 \%$ & & $0.22 \%$ & & $3.23 \%$ & \\
\hline
\end{tabular}

This table presents results of a regression of the unadjusted and adjusted tax avoidance measure on variables utilized in prior research to control for a firm's ability to reduce tax burden, specifically option compensation, property, plant, and equipment, and foreign earnings. See Appendix A and prior panels for variable description. Control variables defined as follows. Options: Average annual value realized from the exercise of options for the top five executives of options by the top five executives grossed up by the fraction of options owned by the covered executives in year t-1 (Execucomp). PPE: Property, plant and equipment, gross $=\left(\mathrm{PPEGT}_{\mathrm{AT}} \mathrm{A}\right)$. Foreign Income : Pre-tax income from foreign operations $=\left(\mathrm{PIFO} / \mathrm{AT}_{\mathrm{t}-1}\right)$. Panel A includes dependent variables CETR AVOID: $35 \%-$ unadjusted CETR; OTHER AVOID : tax avoidance unrelated to stock option tax benefits, accelerated tax depreciation and residual tax deferral $=35 \%$-adjusted CETR and SPECIFIC AVOID : tax avoidance related to stock option tax benefits, accelerated tax depreciation and residual tax deferral. Panel B includes dependent variables CETR AVOID , CETR NO STOCK AVOID : tax avoidance implied by CETR unrelated to stock option tax benefits, STOCK AVOID : tax avoidance from stock option tax benefits, CETR NO DEPR AVOID: tax avoidance implied by the CETR unrelated to accelerated tax depreciation deductions, DEPR AVOID: tax avoidance related to accelerated tax depreciation deductions, CETR NO RESIDUAL AVOID : tax avoidance implied by the CETR unrelated to deferral of residual U.S. tax on foreign earnings and RESIDUAL AVOID : tax avoidance related to deferral of residual U.S. tax on foreign earnings. 
Table 3

Descriptive Statistics

Panel A: Descriptive Statistics for Dependent and Control Variables

\begin{tabular}{|c|c|c|c|c|c|c|}
\hline & $\mathrm{n}$ & Mean & Std. Dev & 25 th & Median & 75 th \\
\hline Tobin's Q & 2612 & 1.7945 & 1.107 & 1.157 & 1.411 & 2.006 \\
\hline Options & 2612 & 0.2457 & 0.266 & 0.0087 & 0.149 & 0.4147 \\
\hline PPE & 2612 & 0.3023 & 0.2605 & 0.0887 & 0.2427 & 0.4757 \\
\hline Size & 2612 & $18,637.6$ & $33,133.6$ & $5,004.2$ & $8,293.1$ & $18,187.5$ \\
\hline Risk & 2612 & 0.1016 & 0.0505 & 0.0678 & 0.0916 & 0.1211 \\
\hline Growth & 2612 & 0.1098 & 0.1833 & 0.01756 & 0.0751 & 0.1583 \\
\hline NOL & 2612 & 0.3974 & 0.4895 & 0 & 0 & 1 \\
\hline Intangible & 2612 & 0.1799 & 0.2182 & 0.0208 & 0.10699 & 0.27387 \\
\hline Firm Age & 2612 & 3.372 & 0.781 & 2.833 & 3.497 & 4.007 \\
\hline Cash & 2612 & 0.1074 & 0.13 & 0.02437 & 0.0596 & 0.1438 \\
\hline Appreciation & 2612 & 0.8626 & 26.512 & -0.2958 & 0.00051 & 0.331 \\
\hline
\end{tabular}

Panel A presents descriptive statistics for dependent and control variables for firm value regression analysis using three-year cumulative tax avoidance measure. Letters in caps are Compustat, CRSP or Execucomp variable name. All \$ values report in millions unless otherwise noted. Tobin's $Q$ : Ratio of market value of firm to book value of firm $=\left((\mathrm{AT})+\left(\left(\mathrm{PRCC} \_\mathrm{C}\right) *(\mathrm{CSHO})\right)-(\mathrm{CEQ})\right) /(\mathrm{AT})$. Options : Average annual value realized from the exercise of options for the top five executives of options by the top five executives grossed up by the fraction of options owned by the covered executives in year $\mathrm{t}-1$ (Execucomp). PPE: Property, plant and equipment, gross $=\left(\mathrm{PPEGT} / \mathrm{AT}_{\mathrm{t}-1}\right)$. Foreign Income $:$ Pre-tax income from foreign operations $=\left(\mathrm{PIFO}_{\mathrm{AT}} \mathrm{t}-1\right)$. Size: Total Sales $(\mathrm{SALE})$. Risk: Standard deviation of monthly stock returns over previous 36 months (CRSP). Growth: 3 year average sales growth from $\mathrm{t}-2$ to $\mathrm{t}=\sum_{\mathrm{t}-2, \mathrm{t}}\left(\mathrm{SALE}_{\mathrm{t}}-\mathrm{SALE}_{\mathrm{t}-1}\right) / \mathrm{SALE}_{\mathrm{t}-1}$. Leverage: Long-term Debt $=$ $(\mathrm{DLTT}+\mathrm{DLC}) /(\mathrm{AT}) . \mathrm{NOL}:=1$ if firm has tax loss Carryforward $(\mathrm{TLCF})$, otherwise $=0$. Intangible $:$ Intangible assets $=\left(\mathrm{INTAN} / \mathrm{AT}_{\mathrm{t}-1}\right)$. Firm Age: $\operatorname{Ln}\left(1+\right.$ number of years listed in Compustat). Cash: Total Cash $=\left(\mathrm{CHE} / \mathrm{AT}_{\mathrm{t}-1}\right)$. Appreciation $:$ cumulative stock price appreciation over prior four years $=\left(\right.$ Price $_{t^{-}}$Price $\left._{t-3}\right) /$ Price $_{t-3}$. 


\begin{tabular}{|c|c|c|c|c|c|c|c|c|c|}
\hline \multicolumn{10}{|c|}{ Table 3} \\
\hline \multicolumn{10}{|c|}{ Descriptive Statistics } \\
\hline \multicolumn{10}{|c|}{ Panel B: Firm Value Regression Correlation Coefficients (3 year Tax Avoidance Measures) } \\
\hline & CETR AVOID3 & $\begin{array}{c}\text { OTHER } \\
\text { AVOID3 }\end{array}$ & STOCK AVOID3 & DEPR AVOID3 & $\begin{array}{c}\text { RESIDUAL } \\
\text { DEFER3 }\end{array}$ & $\mathrm{Q}$ & Option & PPE & $\begin{array}{l}\text { Foreign } \\
\text { Income }\end{array}$ \\
\hline CETR AVOID3 & 1.000 & 0.643 & 0.118 & 0.077 & 0.108 & -0.044 & 0.020 & -0.023 & 0.022 \\
\hline OTHER AVOID3 & 0.514 & 1.000 & -0.076 & -0.438 & -0.065 & -0.070 & -0.076 & -0.212 & 0.055 \\
\hline STOCK AVOID3 & -0.043 & -0.341 & 1.000 & 0.012 & 0.084 & 0.372 & 0.530 & -0.161 & 0.059 \\
\hline DEPR AVOID3 & 0.075 & -0.721 & 0.044 & 1.000 & 0.001 & -0.027 & 0.019 & 0.334 & -0.073 \\
\hline RESIDUAL DEFER & 0.074 & -0.221 & 0.185 & 0.043 & 1.000 & 0.138 & 0.043 & 0.006 & 0.400 \\
\hline $\mathrm{Q}$ & 0.045 & -0.003 & 0.251 & -0.061 & 0.059 & 1.000 & 0.304 & 0.117 & 0.418 \\
\hline Option & 0.046 & -0.054 & 0.358 & -0.025 & 0.037 & 0.342 & 1.000 & -0.068 & 0.054 \\
\hline PPE & 0.010 & -0.186 & -0.077 & 0.268 & -0.002 & -0.017 & -0.058 & 1.000 & 0.037 \\
\hline Foreign Income & 0.004 & -0.005 & -0.016 & -0.038 & 0.213 & 0.431 & 0.085 & 0.042 & 1.000 \\
\hline Size & -0.051 & -0.032 & -0.059 & 0.008 & 0.051 & -0.011 & 0.007 & 0.053 & 0.235 \\
\hline Risk & -0.001 & -0.002 & 0.167 & -0.052 & -0.004 & 0.000 & -0.023 & -0.076 & -0.115 \\
\hline Growth & 0.082 & -0.077 & 0.144 & 0.106 & 0.023 & 0.123 & 0.177 & 0.141 & 0.019 \\
\hline Leverage & 0.038 & 0.029 & -0.142 & 0.052 & -0.029 & -0.206 & -0.187 & 0.188 & -0.199 \\
\hline NOL & 0.023 & 0.045 & 0.007 & -0.049 & 0.035 & 0.016 & -0.025 & -0.050 & 0.096 \\
\hline Intangible & -0.006 & -0.027 & 0.039 & -0.003 & 0.059 & 0.015 & 0.018 & -0.155 & 0.065 \\
\hline Firm Age & -0.025 & -0.005 & -0.209 & 0.050 & 0.040 & -0.065 & -0.153 & 0.166 & 0.173 \\
\hline Cash & 0.065 & 0.016 & 0.273 & -0.070 & 0.076 & 0.362 & 0.201 & -0.269 & 0.208 \\
\hline \multirow[t]{2}{*}{ Appreciation } & 0.040 & 0.012 & -0.008 & 0.018 & -0.005 & -0.012 & -0.025 & 0.041 & 0.002 \\
\hline & Size & Risk & Growth & Leverage & NOL & Intangible & Firm Age & Cash & Appreciation \\
\hline \begin{tabular}{|l|} 
CETR AVOID3 \\
\end{tabular} & -0.010 & 0.032 & 0.006 & 0.050 & 0.036 & -0.021 & -0.033 & 0.021 & 0.060 \\
\hline OTHER AVOID3 & 0.016 & 0.003 & -0.172 & 0.054 & 0.059 & 0.047 & 0.013 & 0.028 & 0.046 \\
\hline STOCK AVOID3 & -0.067 & 0.064 & 0.266 & -0.217 & 0.070 & 0.059 & -0.261 & 0.175 & 0.120 \\
\hline DEPR AVOID3 & 0.004 & -0.097 & 0.175 & 0.051 & -0.050 & -0.055 & 0.066 & -0.173 & 0.057 \\
\hline RESIDUAL DEFER & 0.128 & -0.025 & 0.025 & -0.058 & 0.091 & 0.123 & 0.076 & 0.093 & -0.032 \\
\hline Q & -0.004 & -0.082 & 0.137 & -0.244 & 0.087 & 0.146 & 0.012 & 0.269 & 0.167 \\
\hline Option & 0.066 & -0.080 & 0.258 & -0.202 & -0.023 & -0.017 & -0.122 & 0.108 & 0.069 \\
\hline PPE & 0.015 & -0.092 & 0.012 & 0.252 & -0.030 & -0.148 & 0.249 & -0.339 & 0.016 \\
\hline Foreign Income & 0.158 & -0.097 & -0.031 & -0.168 & 0.184 & 0.255 & 0.188 & 0.189 & 0.033 \\
\hline Size & 1.000 & -0.236 & 0.006 & -0.057 & -0.001 & 0.044 & 0.249 & 0.062 & -0.099 \\
\hline Risk & -0.151 & 1.000 & -0.057 & -0.026 & 0.118 & -0.114 & -0.330 & 0.187 & -0.221 \\
\hline Growth & 0.019 & 0.002 & 1.000 & -0.091 & -0.028 & 0.023 & -0.209 & 0.025 & 0.214 \\
\hline Leverage & -0.084 & 0.069 & -0.003 & 1.000 & -0.053 & 0.084 & 0.133 & -0.418 & -0.054 \\
\hline $\mathrm{NOL}$ & -0.034 & 0.113 & -0.008 & -0.023 & 1.000 & 0.146 & -0.143 & 0.082 & 0.030 \\
\hline Intangible & -0.020 & -0.104 & 0.070 & 0.038 & 0.097 & 1.000 & 0.011 & -0.082 & 0.002 \\
\hline Firm Age & 0.163 & -0.299 & -0.193 & 0.070 & -0.165 & -0.063 & 1.000 & -0.115 & -0.054 \\
\hline Cash & -0.017 & 0.196 & 0.079 & -0.276 & 0.046 & -0.037 & -0.175 & 1.000 & 0.036 \\
\hline Appreciation & 0.003 & 0.052 & 0.017 & -0.026 & 0.036 & 0.014 & -0.085 & 0.046 & 1.000 \\
\hline
\end{tabular}




\begin{tabular}{|c|c|c|c|c|c|c|c|}
\hline \multicolumn{8}{|c|}{ Table 4} \\
\hline \multicolumn{8}{|c|}{ Descriptive Statistics for Dependent, Tax Avoidance and Control Variables in Tax Haven Firm Value Analysis } \\
\hline & \multicolumn{3}{|c|}{ No Tax Haven Firm Year Observations } & \multicolumn{3}{|c|}{ Tax Haven Firm Year Observations } & \multirow{2}{*}{$\begin{array}{c}\text { T-test of } \\
\text { Difference in } \\
\text { Means } \\
\text { p-value }\end{array}$} \\
\hline & $\mathrm{n}^{\mathrm{a}}$ & Mean & Std. Dev & $\mathrm{n}^{\mathrm{a}}$ & Mean & Std. Dev & \\
\hline PRE & 526 & 2429.4 & 2429.4 & 806 & 3884.9 & 9025 & 0.0008 \\
\hline PRE TAX Reported & 118 & 442.8 & 924.3 & 209 & 458.7 & 1017 & 0.8882 \\
\hline PRE TAX Estimate B\&S & 504 & 419.7 & 1184.2 & 772 & 714.3 & 1918.3 & 0.0021 \\
\hline PRE TAX Estimate Krull & 504 & 242 & 813.2 & 772 & 441.2 & 1311.5 & 0.0024 \\
\hline DTL FOR & 138 & -92.648 & 246.4 & 192 & -552.4 & 1502.6 & $<.0001$ \\
\hline Tobin's Q & 1331 & 1.7935 & 1.131 & 1281 & 1.796 & 1.083 & 0.9599 \\
\hline Options & 1331 & 0.248 & 0.273 & 1281 & 0.244 & 0.259 & 0.7224 \\
\hline PPE & 1331 & 0.3352 & 0.2812 & 1281 & 0.2682 & 0.2324 & $<.0001$ \\
\hline Foreign Income & 1331 & 0.0184 & 0.041 & 1281 & 0.03 & 0.045 & $<.0001$ \\
\hline Size & 1331 & $16,496.4$ & $31,999.4$ & 1281 & $20,862.4$ & $34,142.7$ & 0.0008 \\
\hline Risk & 1331 & 0.102 & 0.0484 & 1281 & 0.101 & 0.053 & 0.8866 \\
\hline Growth & 1331 & 0.1213 & 0.213 & 1281 & 0.0978 & 0.1452 & 0.0011 \\
\hline Leverage & 1331 & 0.2761 & 0.167 & 1281 & 0.2413 & 0.1637 & $<.0001$ \\
\hline NOL & 1331 & 0.3727 & 0.4837 & 1281 & 0.4231 & 0.4942 & 0.0084 \\
\hline Intang & 1331 & 0.1557 & 0.2282 & 1281 & 0.2049 & 0.204 & $<.0001$ \\
\hline Firm Age & 1331 & 3.39 & 0.752 & 1281 & 3.353 & 0.8106 & 0.2291 \\
\hline Cash & 1331 & 0.0981 & 0.132 & 1281 & 0.117 & 0.1274 & 0.0002 \\
\hline Appreciation & 1331 & 0.792 & 24.497 & 1281 & 0.9361 & 28.464 & 0.8896 \\
\hline CETR3 & 1331 & $24.90 \%$ & 0.145 & 1281 & $24.09 \%$ & 0.138 & 0.1442 \\
\hline CETR AVOID3 & 1331 & $10.10 \%$ & 0.145 & 1281 & $10.91 \%$ & 0.138 & 0.1442 \\
\hline STOCK AVOID3 & 1331 & $2.54 \%$ & 0.062 & 1281 & $2.48 \%$ & 0.06 & 0.8134 \\
\hline DEPR AVOID3 & 1331 & $4.5 \%$ & 0.2013 & 1281 & $2.46 \%$ & 0.1789 & 0.007 \\
\hline RESIDUAL AVOID3 BS & 1331 & $1.16 \%$ & 0.0423 & 1281 & $2.06 \%$ & 0.0571 & $<.0001$ \\
\hline RESIDUAL AVOID3 KRULL & 1331 & $0.80 \%$ & 0.037 & 1281 & $1.37 \%$ & 0.0536 & 0.0018 \\
\hline OTHER AVOID3 BS & 1331 & $2.18 \%$ & 0.2513 & 1281 & $4.05 \%$ & 0.2258 & 0.046 \\
\hline OTHER AVOID3 KRULL & 1331 & $2.48 \%$ & 0.2503 & 1281 & $4.70 \%$ & 0.2245 & 0.0171 \\
\hline $\begin{array}{l}\text { This table presents descriptive s } \\
\text { cumulative tax avoidance meast } \\
\text { crawler technology. See Appen } \\
\text { presented for observations havir } \\
\text { haven status. T-test for differen }\end{array}$ & by tax & atus. Firm & nalysis dep & $\begin{array}{l}\text { firm v } \\
\text { Linds } \\
\text { mparis } \\
\text { tax av }\end{array}$ & $\begin{array}{l}\text { haven regre } \\
\text { ). Tax have } \\
\text { nd collected } \\
\text { and control }\end{array}$ & $\begin{array}{l}\text { analysis us } \\
\text { isdictions ar } \\
\text { lual tax defe } \\
\text { bles are als }\end{array}$ & $\begin{array}{l}\text { ree-year } \\
\text { tified using web } \\
\text { ariables are } \\
\text { ented by tax }\end{array}$ \\
\hline
\end{tabular}




\begin{tabular}{|c|c|c|c|c|c|c|c|}
\hline \multicolumn{8}{|c|}{ Table 5A } \\
\hline \multicolumn{8}{|c|}{ Descriptive Statistics } \\
\hline \multicolumn{8}{|c|}{ Panel A: Descriptive Statistics for Dependent, Tax Avoidance and Control Variables in Agency Analysis - G-Index } \\
\hline \multirow{3}{*}{ G-Index } & $\mathrm{n}^{\mathrm{a}}$ & Mean & Std. Dev & 25 th & Median & 75 th & 90th \\
\hline & 2612 & 9.896 & 2.499 & 8 & 10 & 12 & 14 \\
\hline & \multicolumn{3}{|c|}{ Well Governed Firm Year Observations } & \multicolumn{3}{|c|}{ Poorly Governed Firm Year Observations } & $\begin{array}{c}\text { T-test of } \\
\text { Difference in } \\
\text { Means }\end{array}$ \\
\hline & $\mathrm{n}^{\mathrm{a}}$ & Mean & Std. Dev & $\mathrm{n}^{\mathrm{a}}$ & Mean & Std. Dev & p-value \\
\hline & \multicolumn{7}{|c|}{ Governance Assignment 1 Mean: (Poor G = G-Index > Sample Mean 9.896) } \\
\hline Tobin's Q & 1202 & 1.923 & 1.2735 & 1410 & 1.685 & 0.929 & $<.0001$ \\
\hline Options & 1202 & 0.2704 & 0.281 & 1410 & 0.2248 & 0.2512 & $<.0001$ \\
\hline PPE & 1202 & 0.2865 & 0.2533 & 1410 & 0.3158 & 0.266 & 0.0042 \\
\hline Foreign Income & 1202 & 0.0258 & 0.0464 & 1410 & 0.0229 & 0.04 & 0.0889 \\
\hline Size & 1202 & $24,642.8$ & $45,187.5$ & 1410 & $13,518.3$ & $15,392.1$ & $<.0001$ \\
\hline Risk & 1202 & 0.1053 & 0.0538 & 1410 & 0.0985 & 0.0472 & 0.0006 \\
\hline Growth & 1202 & 0.1247 & 0.1878 & 1410 & 0.0971 & 0.1785 & 0.0001 \\
\hline Leverage & 1202 & 0.2603 & 0.1898 & 1410 & 0.258 & 0.1433 & 0.7244 \\
\hline NOL & 1202 & 0.3802 & 0.4856 & 1410 & 0.4121 & 0.4924 & 0.0973 \\
\hline Intang & 1202 & 0.1726 & 0.2458 & 1410 & 0.1861 & 0.1815 & 0.1171 \\
\hline Firm Age & 1202 & 3.2605 & 0.8163 & 1410 & 3.467 & 0.7373 & $<.0001$ \\
\hline Cash & 1202 & 0.1258 & 0.1449 & 1410 & 0.0917 & 0.1137 & $<.0001$ \\
\hline Appreciation & 1202 & 0.9613 & 29.3827 & 1410 & 0.7785 & 23.8034 & 0.8606 \\
\hline CETR3 & 1202 & $24.66 \%$ & 0.1464 & 1410 & $24.38 \%$ & 0.1373 & 0.6117 \\
\hline CETR AVOID3 & 1202 & $10.34 \%$ & 0.1464 & 1410 & $10.62 \%$ & 0.1373 & 0.6117 \\
\hline STOCK AVOID3 & 1202 & $3.05 \%$ & 0.0753 & 1410 & $2.05 \%$ & 0.0451 & $<.0001$ \\
\hline DEPR AVOID3 & 1202 & $2.7 \%$ & 0.1949 & 1410 & $4.17 \%$ & 0.1872 & 0.046 \\
\hline RESIDUAL AVOID3 BS & 1202 & $1.55 \%$ & 0.0493 & 1410 & $1.65 \%$ & 0.0512 & 0.6313 \\
\hline RESIDUAL AVOID3 KRU] & 1202 & $1.08 \%$ & 0.043 & 1410 & $1.08 \%$ & 0.0486 & 0.9707 \\
\hline OTHER AVOID3 BS & 1202 & $3.23 \%$ & 0.2434 & 1410 & $2.98 \%$ & 0.2358 & 0.7939 \\
\hline \multirow[t]{2}{*}{ OTHER AVOID3 KRULL } & 1202 & $3.70 \%$ & 0.2424 & 1410 & $3.46 \%$ & 0.2346 & 0.7951 \\
\hline & \multicolumn{7}{|c|}{ Governance Assignment 2 Third Quartile: (Poor G = G-Index > Sample Third Quartile 12) } \\
\hline Tobin's Q & 1949 & 1.8291 & 1.1638 & 663 & 1.6928 & 0.9145 & 0.0062 \\
\hline Options & 1949 & 0.2548 & 0.2749 & 663 & 0.2192 & 0.2367 & 0.003 \\
\hline PPE & 1949 & 0.3075 & 0.2702 & 663 & 0.2873 & 0.2295 & 0.0857 \\
\hline Foreign Income & 1949 & 0.024 & 0.0448 & 663 & 0.0247 & 0.0375 & 0.7495 \\
\hline Size & 1949 & $21,158.3$ & $37,200.9$ & 663 & $11,227.7$ & $13,564.6$ & $<.0001$ \\
\hline Risk & 1949 & 0.1016 & 0.0512 & 663 & 0.1015 & 0.0481 & 0.9794 \\
\hline Growth & 1949 & 0.1173 & 0.1968 & 663 & 0.0878 & 0.1339 & 0.0003 \\
\hline Leverage & 1949 & 0.2631 & 0.1763 & 663 & 0.247 & 0.132 & 0.0306 \\
\hline NOL & 1949 & 0.391 & 0.4881 & 663 & 0.4163 & 0.4933 & 0.25 \\
\hline Intang & 1949 & 0.1736 & 0.2264 & 663 & 0.1984 & 0.1911 & 0.0113 \\
\hline Firm Age & 1949 & 3.3067 & 0.8121 & 663 & 3.5639 & 0.6461 & $<.0001$ \\
\hline Cash & 1949 & 0.1143 & 0.1377 & 663 & 0.0871 & 0.102 & $<.0001$ \\
\hline Appreciation & 1949 & 1.1213 & 30.6867 & 663 & 0.1023 & 0.7228 & 0.3928 \\
\hline CETR3 & 1949 & $24.88 \%$ & 0.1448 & 663 & $23.42 \%$ & 0.1312 & 0.0224 \\
\hline CETR AVOID3 & 1949 & $10.12 \%$ & 0.1448 & 663 & $11.58 \%$ & 0.1312 & 0.0224 \\
\hline STOCK AVOID3 & 1949 & $2.67 \%$ & 0.0637 & 663 & $2.04 \%$ & 0.0523 & 0.0222 \\
\hline DEPR AVOID3 & 1949 & $3.6 \%$ & 0.2061 & 663 & $3.12 \%$ & 0.137 & 0.5645 \\
\hline RESIDUAL AVOID3 BS & 1949 & $1.50 \%$ & 0.0497 & 663 & $1.90 \%$ & 0.052 & 0.0799 \\
\hline RESIDUAL AVOID3 KRU] & 1949 & $1.03 \%$ & 0.0472 & 663 & $1.24 \%$ & 0.0429 & 0.3113 \\
\hline OTHER AVOID3 BS & 1949 & $2.50 \%$ & 0.2483 & 663 & $4.85 \%$ & 0.2098 & 0.0287 \\
\hline OTHER AVOID3 KRULL & 1949 & $2.95 \%$ & 0.2477 & 663 & $5.39 \%$ & 0.2069 & 0.0228 \\
\hline
\end{tabular}




\begin{tabular}{|c|c|c|c|c|c|c|c|}
\hline \multicolumn{8}{|c|}{ Table 5A } \\
\hline \multicolumn{8}{|c|}{ Descriptive Statistics } \\
\hline \multicolumn{8}{|c|}{ Panel A (Continued): Descriptive Statistics for Dependent, Tax Avoidance and Control Variables in Agency Analysis - G-Index } \\
\hline & \multicolumn{3}{|c|}{ Well Governed Firm Year Observations } & Poorly & Firm Year & ervations & $\begin{array}{c}\text { T-test of } \\
\text { Difference in } \\
\text { Means }\end{array}$ \\
\hline & $\mathrm{n}^{\mathrm{a}}$ & Mean & Std. Dev & $\mathrm{n}^{\mathrm{a}}$ & Mean & Std. Dev & p-value \\
\hline & \multicolumn{7}{|c|}{ Governance Assignment 3 Top Decile: (Poor G = G-Index > Top Decile 14) } \\
\hline Tobin's Q & 2415 & 1.8163 & 1.1415 & 197 & 1.5274 & 0.4538 & 0.0004 \\
\hline Options & 2415 & 0.2495 & 0.2693 & 197 & 0.1998 & 0.2198 & 0.0118 \\
\hline PPE & 2415 & 0.3017 & 0.2611 & 197 & 0.3104 & 0.2539 & 0.6533 \\
\hline Foreign Income & 2415 & 0.0246 & 0.0439 & 197 & 0.0187 & 0.0301 & 0.0643 \\
\hline Size & 2415 & $19,484.9$ & $34,278.4$ & 197 & $8,250.7$ & $5,969.2$ & $<.0001$ \\
\hline Risk & 2415 & 0.102 & 0.0513 & 197 & 0.0964 & 0.0382 & 0.1321 \\
\hline Growth & 2415 & 0.112 & 0.186 & 197 & 0.0826 & 0.1433 & 0.03 \\
\hline Leverage & 2415 & 0.2583 & 0.1682 & 197 & 0.2678 & 0.1405 & 0.4436 \\
\hline NOL & 2415 & 0.3975 & 0.4895 & 197 & 0.3959 & 0.4903 & 0.9653 \\
\hline Intang & 2415 & 0.1793 & 0.2216 & 197 & 0.1867 & 0.1715 & 0.649 \\
\hline Firm Age & 2415 & 3.3516 & 0.7954 & 197 & 3.6215 & 0.522 & 0.0001 \\
\hline Cash & 2415 & 0.1105 & 0.1325 & 197 & 0.0696 & 0.088 & $<.0001$ \\
\hline Appreciation & 2415 & 0.919 & 25.5714 & 197 & 0.1714 & 0.5592 & 0.7036 \\
\hline CETR3 & 2415 & $24.51 \%$ & 0.1425 & 197 & $24.41 \%$ & 0.1297 & 0.9201 \\
\hline CETR AVOID3 & 2415 & $10.49 \%$ & 0.1425 & 197 & $10.59 \%$ & 0.1297 & 0.9201 \\
\hline STOCK AVOID3 & 2415 & $2.57 \%$ & 0.062 & 197 & $1.71 \%$ & 0.0471 & 0.0577 \\
\hline DEPR AVOID3 & 2415 & $3.5 \%$ & 0.1924 & 197 & $3.07 \%$ & 0.1724 & 0.7515 \\
\hline RESIDUAL AVOID3 BS & 2415 & $1.66 \%$ & 0.051 & 197 & $0.96 \%$ & 0.0404 & 0.0619 \\
\hline RESIDUAL AVOID3 KRU] & 2415 & $1.14 \%$ & 0.0473 & 197 & $0.30 \%$ & 0.0269 & 0.0137 \\
\hline OTHER AVOID3 BS & 2415 & $2.94 \%$ & 0.241 & 197 & $5.01 \%$ & 0.217 & 0.2419 \\
\hline OTHER AVOID3 KRULL & 2415 & $3.40 \%$ & 0.2396 & 197 & $5.69 \%$ & 0.2191 & 0.1945 \\
\hline \multicolumn{8}{|c|}{ Governance Assignment 4 Extreme Quartiles: (Poor G = G-Index > TopQuartile 12 /Strong G = G-Index $<$ Low Quartile 8 ) } \\
\hline Tobin's Q & 816 & 1.8815 & 1.2763 & 663 & 1.6928 & 0.9145 & 0.0014 \\
\hline Options & 816 & 0.263 & 0.2778 & 663 & 0.2192 & 0.2367 & 0.0013 \\
\hline PPE & 816 & 0.2768 & 0.2493 & 663 & 0.2873 & 0.2295 & 0.4036 \\
\hline Foreign Income & 816 & 0.024 & 0.046 & 663 & 0.0247 & 0.0375 & 0.753 \\
\hline Size & 816 & $27,304.9$ & $51,660.9$ & 663 & $11,227.7$ & $13,564.6$ & $<.0001$ \\
\hline Risk & 816 & 0.1077 & 0.0575 & 663 & 0.1015 & 0.0481 & 0.0286 \\
\hline Growth & 816 & 0.1294 & 0.1981 & 663 & 0.0878 & 0.1339 & $<.0001$ \\
\hline Leverage & 816 & 0.2604 & 0.1993 & 663 & 0.247 & 0.132 & 0.1377 \\
\hline NOL & 816 & 0.3529 & 0.4782 & 663 & 0.4163 & 0.4933 & 0.0126 \\
\hline Intang & 816 & 0.1625 & 0.2424 & 663 & 0.1984 & 0.1911 & 0.0019 \\
\hline Firm Age & 816 & 3.243 & 0.8051 & 663 & 3.5639 & 0.6461 & $<.0001$ \\
\hline Cash & 816 & 0.1312 & 0.1491 & 663 & 0.0871 & 0.102 & $<.0001$ \\
\hline Appreciation & 816 & 1.3572 & 35.658 & 663 & 0.1023 & 0.7228 & 0.3651 \\
\hline CETR3 & 816 & $24.74 \%$ & 0.1415 & 663 & $23.42 \%$ & 0.1312 & 0.0664 \\
\hline CETR AVOID3 & 816 & $10.26 \%$ & 0.1415 & 663 & $11.58 \%$ & 0.1312 & 0.0664 \\
\hline STOCK AVOID3 & 816 & $2.74 \%$ & 0.0653 & 663 & $2.04 \%$ & 0.0523 & 0.0253 \\
\hline DEPR AVOID3 & 816 & $2.9 \%$ & 0.2047 & 663 & $3.12 \%$ & 0.137 & 0.8194 \\
\hline RESIDUAL AVOID3 BS & 816 & $1.43 \%$ & 0.0502 & 663 & $1.90 \%$ & 0.052 & 0.0766 \\
\hline RESIDUAL AVOID3 KRU] & 816 & $0.92 \%$ & 0.043 & 663 & $1.24 \%$ & 0.0429 & 0.1611 \\
\hline OTHER AVOID3 BS & 816 & $3.37 \%$ & 0.2401 & 663 & $4.85 \%$ & 0.2098 & 0.2119 \\
\hline OTHER AVOID3 KRULL & 816 & $3.87 \%$ & 0.2391 & 663 & $5.39 \%$ & 0.2069 & 0.1973 \\
\hline
\end{tabular}




\begin{tabular}{|c|c|c|c|c|c|c|c|c|}
\hline \multicolumn{9}{|c|}{ Table 5A } \\
\hline \multicolumn{9}{|c|}{ Correlation Coefficients } \\
\hline \multicolumn{9}{|c|}{ Panel B: Governance Correlation Coefficients (Poor G = G-Index > 9.69) } \\
\hline & OTHER AVOID3 & STOCK AVOID3 & DEPR AVOID3 & RESIDUAL DEFER3 & $\begin{array}{c}\text { OTHER } \\
\text { AVOID3* PoorG }\end{array}$ & $\begin{array}{c}\text { STOCK } \\
\text { AVOID3* PoorG }\end{array}$ & $\begin{array}{c}\text { DEPR } \\
\text { AVOID3* } \\
\text { PoorG }\end{array}$ & $\begin{array}{c}\text { RESIDUAL } \\
\text { DEFER3* PoorG }\end{array}$ \\
\hline OTHER AVOID3 & 1.000 & -0.072 & -0.430 & -0.067 & 0.663 & 0.008 & -0.268 & -0.034 \\
\hline STOCK AVOID3 & -0.342 & 1.000 & 0.013 & 0.077 & -0.008 & 0.407 & 0.019 & 0.045 \\
\hline DEPR AVOID3 & -0.709 & 0.036 & 1.000 & 0.006 & -0.279 & 0.091 & 0.718 & 0.039 \\
\hline RESIDUAL DEFER3 & -0.229 & 0.185 & 0.046 & 1.000 & -0.018 & 0.032 & 0.011 & 0.703 \\
\hline OTHER AVOID3*PoorG & 0.724 & -0.179 & -0.518 & -0.192 & 1.000 & 0.220 & -0.238 & 0.064 \\
\hline STOCK AVOID3*PoorG & -0.222 & 0.497 & 0.037 & 0.131 & -0.270 & 1.000 & 0.301 & 0.274 \\
\hline DEPR AVOID3*PoorG & -0.523 & 0.004 & 0.725 & 0.044 & -0.697 & 0.075 & 1.000 & 0.128 \\
\hline RESIDUAL DEFER3*Poor( & -0.180 & 0.084 & 0.050 & 0.768 & -0.230 & 0.211 & 0.080 & 1.000 \\
\hline Q & -0.002 & 0.252 & -0.060 & 0.052 & 0.005 & 0.081 & -0.069 & 0.001 \\
\hline Poor G & -0.009 & -0.083 & 0.053 & -0.004 & 0.099 & 0.293 & 0.155 & 0.146 \\
\hline Option & -0.053 & 0.359 & -0.026 & 0.034 & -0.026 & 0.181 & -0.034 & -0.001 \\
\hline PPE & -0.194 & -0.076 & 0.275 & -0.001 & -0.177 & -0.020 & 0.259 & 0.035 \\
\hline Foreign Income & -0.004 & -0.019 & -0.037 & 0.205 & 0.022 & -0.040 & -0.059 & 0.128 \\
\hline & $\mathrm{Q}$ & Poor G & Option & PPE & Foreign Income & & & \\
\hline OTHER AVOID3 & -0.072 & 0.008 & -0.076 & -0.220 & 0.055 & & & \\
\hline STOCK AVOID3 & 0.374 & -0.024 & 0.535 & -0.160 & 0.051 & & & \\
\hline DEPR AVOID3 & -0.021 & 0.097 & 0.020 & 0.341 & -0.069 & & & \\
\hline RESIDUAL DEFER3 & 0.135 & -0.012 & 0.040 & 0.007 & 0.398 & & & \\
\hline OTHER AVOID3*PoorG & -0.003 & 0.278 & -0.032 & -0.163 & 0.096 & & & \\
\hline STOCK AVOID3*PoorG & 0.094 & 0.756 & 0.170 & -0.014 & 0.023 & & & \\
\hline DEPR AVOID3*PoorG & -0.030 & 0.345 & 0.018 & 0.203 & -0.065 & & & \\
\hline RESIDUAL DEFER3*Poor & 0.065 & 0.291 & 0.028 & 0.045 & 0.266 & & & \\
\hline Q & 1.000 & -0.073 & 0.305 & 0.118 & 0.418 & & & \\
\hline Poor G & -0.121 & 1.000 & -0.077 & 0.052 & -0.008 & & & \\
\hline Option & 0.341 & -0.103 & 1.000 & -0.071 & 0.052 & & & \\
\hline PPE & -0.016 & 0.041 & -0.060 & 1.000 & 0.042 & & & \\
\hline Foreign Income & 0.427 & -0.049 & 0.080 & 0.045 & 1.000 & & & \\
\hline
\end{tabular}




\begin{tabular}{|c|c|c|c|c|c|c|c|}
\hline \multicolumn{8}{|c|}{ Table 5B } \\
\hline \multicolumn{8}{|c|}{ Descriptive Statistics } \\
\hline \multicolumn{8}{|c|}{ Panel A: Descriptive Statistics for Dependent and Control Variables in Agency Analysis - E-Index } \\
\hline \multirow{3}{*}{ E-Index } & $\mathrm{n}^{\mathrm{a}}$ & Mean & Std. Dev & 25 th & Median & 75th & 90th \\
\hline & 2484 & 2.735 & 1.359 & 2 & 3 & 4 & 5 \\
\hline & \multicolumn{3}{|c|}{ Well Governed Firm Year Observations } & \multicolumn{3}{|c|}{ Poorly Governed Firm Year Observations } & $\begin{array}{c}\text { T-test of } \\
\text { Difference in } \\
\text { Means }\end{array}$ \\
\hline & $\mathrm{n}^{\mathrm{a}}$ & Mean & Std. Dev & $\mathrm{n}^{\mathrm{a}}$ & Mean & Std. Dev & p-value \\
\hline & \multicolumn{7}{|c|}{ Governance Assignment 1 Mean: (Poor G = E-Index > Sample Mean 2.735) } \\
\hline Tobin's Q & 1141 & 2.013 & 1.328 & 1471 & 1.625 & 0.8625 & $<.0001$ \\
\hline Options & 1141 & 0.2828 & 0.2907 & 1471 & 0.217 & 0.2417 & $<.0001$ \\
\hline PPE & 1141 & 0.2881 & 0.243 & 1471 & 0.3134 & 0.273 & 0.0137 \\
\hline Foreign Income & 1141 & 0.0291 & 0.0482 & 1471 & 0.0204 & 0.0382 & $<.0001$ \\
\hline Size & 1141 & $23,084.0$ & $41,768.0$ & 1471 & $15,189.0$ & $23,871.0$ & $<.0001$ \\
\hline Risk & 1141 & 0.1041 & 0.0549 & 1471 & 0.0997 & 0.0466 & 0.0277 \\
\hline Growth & 1141 & 0.1199 & 0.1859 & 1471 & 0.1019 & 0.1809 & 0.0129 \\
\hline Leverage & 1141 & 0.2628 & 0.1894 & 1471 & 0.2561 & 0.1459 & 0.3083 \\
\hline NOL & 1141 & 0.3742 & 0.4841 & 1471 & 0.4154 & 0.493 & 0.0331 \\
\hline Intang & 1141 & 0.18 & 0.2242 & 1471 & 0.1798 & 0.2136 & 0.9804 \\
\hline Firm Age & 1141 & 3.331 & 0.8097 & 1471 & 3.404 & 0.7573 & 0.0184 \\
\hline Cash & 1141 & 0.1267 & 0.1533 & 1471 & 0.0924 & 0.1063 & $<.0001$ \\
\hline Appreciation & 1141 & 1.7779 & 40.942 & 1471 & 0.1527 & 0.8007 & 0.1202 \\
\hline CETR3 & 1141 & $24.41 \%$ & 0.1401 & 1471 & $24.58 \%$ & 0.1428 & 0.763 \\
\hline CETR AVOID3 & 1141 & $10.59 \%$ & 0.1401 & 1471 & $10.42 \%$ & 0.1428 & 0.763 \\
\hline STOCK AVOID3 & 1141 & $3.32 \%$ & 0.0778 & 1471 & $1.88 \%$ & 0.0429 & $<.0001$ \\
\hline DEPR AVOID3 & 1141 & $3.41 \%$ & 0.2043 & 1471 & $3.55 \%$ & 0.1799 & 0.856 \\
\hline RESIDUAL AVOID3 BS & 1141 & $1.73 \%$ & 0.0529 & 1471 & $1.51 \%$ & 0.0482 & 0.2741 \\
\hline RESIDUAL AVOID3 KRUL & 1141 & $1.20 \%$ & 0.0505 & 1471 & $0.98 \%$ & 0.0425 & 0.2286 \\
\hline OTHER AVOID3 BS & 1141 & $2.32 \%$ & 0.2489 & 1471 & $3.70 \%$ & 0.2314 & 0.1453 \\
\hline \multirow[t]{2}{*}{ OTHER AVOID3 KRULL } & 1141 & $2.81 \%$ & 0.2484 & 1471 & $4.16 \%$ & 0.2298 & 0.151 \\
\hline & \multicolumn{7}{|c|}{ Governance Assignment 2 Third Quartile: (Poor G = E-Index > Sample Third Quartile 4) } \\
\hline Tobin's Q & 1834 & 1.874 & 1.185 & 778 & 1.606 & 0.08692 & $<.0001$ \\
\hline Options & 1834 & 0.2565 & 0.2742 & 778 & 0.2203 & 0.2444 & 0.0015 \\
\hline PPE & 1834 & 0.2997 & 0.2619 & 778 & 0.3085 & 0.2575 & 0.4325 \\
\hline Foreign Income & 1834 & 0.0251 & 0.0451 & 778 & 0.022 & 0.0379 & 0.0917 \\
\hline Size & 1834 & $20,472.7$ & $37,192.1$ & 778 & $14,311.7$ & $19,981.1$ & $<.0001$ \\
\hline Risk & 1834 & 0.1016 & 0.0516 & 778 & 0.1016 & 0.0476 & 0.9929 \\
\hline Growth & 1834 & 0.1214 & 0.1987 & 778 & 0.0824 & 0.1368 & $<.0001$ \\
\hline Leverage & 1834 & 0.2653 & 0.176 & 778 & 0.2443 & 0.1399 & 0.0033 \\
\hline NOL & 1834 & 0.3839 & 0.4865 & 778 & 0.4293 & 0.4953 & 0.03 \\
\hline Intang & 1834 & 0.1806 & 0.2305 & 778 & 0.1782 & 0.1864 & 0.7947 \\
\hline Firm Age & 1834 & 3.363 & 0.7982 & 778 & 3.394 & 0.74 & 0.354 \\
\hline Cash & 1834 & 0.1149 & 0.1401 & 778 & 0.0898 & 0.1005 & $<.0001$ \\
\hline Appreciation & 1834 & 1.1849 & 31.633 & 778 & 0.1028 & 0.7445 & 0.3402 \\
\hline CETR3 & 1834 & $24.07 \%$ & 0.1419 & 778 & $25.55 \%$ & 0.1404 & 0.0146 \\
\hline CETR AVOID3 & 1834 & $10.93 \%$ & 0.1419 & 778 & $9.45 \%$ & 0.1404 & 0.0146 \\
\hline STOCK AVOID3 & 1834 & $2.80 \%$ & 0.0671 & 778 & $1.81 \%$ & 0.0428 & 0.0002 \\
\hline DEPR AVOID3 & 1834 & $3.59 \%$ & 0.2012 & 778 & $3.24 \%$ & 0.1641 & 0.6709 \\
\hline RESIDUAL AVOID3 BS & 1834 & $1.47 \%$ & 0.0512 & 778 & $1.91 \%$ & 0.048 & 0.042 \\
\hline RESIDUAL AVOID3 KRUL & 1834 & $0.98 \%$ & 0.0486 & 778 & $1.31 \%$ & 0.0396 & 0.1007 \\
\hline OTHER AVOID3 BS & 1834 & $3.24 \%$ & 0.251 & 778 & $2.75 \%$ & 0.209 & 0.6316 \\
\hline OTHER AVOID3 KRULL & 1834 & $3.67 \%$ & 0.2493 & 778 & $3.33 \%$ & 0.2099 & 0.7391 \\
\hline
\end{tabular}




\begin{tabular}{|c|c|c|c|c|c|c|c|}
\hline \multicolumn{8}{|c|}{ Table 5B } \\
\hline \multicolumn{8}{|c|}{ Descriptive Statistics } \\
\hline \multicolumn{8}{|c|}{ Panel A (Continued): Descriptive Statistics for Dependent, Tax Avoidance and Control Variables in Agency Analysis - E-Index } \\
\hline & \multicolumn{3}{|c|}{ Well Governed Firm Year Observations } & \multicolumn{3}{|c|}{ Poorly Governed Firm Year Observations } & $\begin{array}{c}\text { T-test of } \\
\text { Difference in } \\
\text { Means }\end{array}$ \\
\hline & $\mathrm{n}^{\mathrm{a}}$ & Mean & Std. Dev & $\mathrm{n}^{\mathrm{a}}$ & Mean & Std. Dev & p-value \\
\hline & \multicolumn{7}{|c|}{ Governance Assignment 3 Top Decile: (Poor G = E-Index > Top Decile 5) } \\
\hline Tobin's Q & 2393 & 1.8246 & 1.434 & 219 & 1.4654 & 0.4699 & $<.0001$ \\
\hline Options & 2393 & 0.251 & 0.2485 & 219 & 0.2156 & 0.2541 & 0.0798 \\
\hline PPE & 2393 & 0.3004 & 0.2596 & 219 & 0.3234 & 0.2707 & 0.2121 \\
\hline Foreign Income & 2393 & 0.0244 & 0.0434 & 219 & 0.0224 & 0.0393 & 0.5228 \\
\hline Size & 2393 & $19,148.6$ & $34,053.7$ & 219 & $13,054.6$ & $19,756.9$ & 0.0092 \\
\hline Risk & 2393 & 0.1012 & 0.0496 & 219 & 0.1059 & 0.0588 & 0.1834 \\
\hline Growth & 2393 & 0.1134 & 0.1862 & 219 & 0.0704 & 0.1428 & 0.0009 \\
\hline Leverage & 2393 & 0.258 & 0.1677 & 219 & 0.2699 & 0.1496 & 0.3126 \\
\hline NOL & 2393 & 0.3957 & 0.4891 & 219 & 0.4155 & 0.4939 & 0.567 \\
\hline Intang & 2393 & 0.1808 & 0.2216 & 219 & 0.1698 & 0.1778 & 0.4735 \\
\hline Firm Age & 2393 & 3.3645 & 0.7906 & 219 & 3.454 & 0.6674 & 0.1047 \\
\hline Cash & 2393 & 0.1094 & 0.1326 & 219 & 0.0857 & 0.0954 & 0.01 \\
\hline Appreciation & 2393 & 0.9373 & 27.6967 & 219 & 0.0463 & 0.8777 & 0.6341 \\
\hline CETR3 & 2393 & $24.37 \%$ & 0.1415 & 219 & $26.03 \%$ & 0.1411 & 0.0959 \\
\hline CETR AVOID3 & 2393 & $10.63 \%$ & 0.1415 & 219 & $0.09 \%$ & 0.1411 & 0.0959 \\
\hline STOCK AVOID3 & 2393 & $2.62 \%$ & 0.0634 & 219 & $1.33 \%$ & 0.0194 & 0.0029 \\
\hline DEPR AVOID3 & 2393 & $3.47 \%$ & 0.195 & 219 & $3.67 \%$ & 0.1381 & 0.8795 \\
\hline RESIDUAL AVOID3 BS & 2393 & $1.57 \%$ & 0.0505 & 219 & $1.97 \%$ & 0.0482 & 0.263 \\
\hline RESIDUAL AVOID3 KRUL & 2393 & $1.06 \%$ & 0.0467 & 219 & $1.31 \%$ & 0.0387 & 0.4351 \\
\hline OTHER AVOID3 BS & 2393 & $3.19 \%$ & 0.2442 & 219 & $2.05 \%$ & 0.1776 & 0.4983 \\
\hline OTHER AVOID3 KRULL & 2393 & $3.65 \%$ & 0.2429 & 219 & $2.69 \%$ & 0.1789 & 0.5674 \\
\hline \multicolumn{8}{|c|}{ Governance Assignment 4 Exterme Quartiles: (Poor G = E-Index > TopQuartile 4 /Strong G = G-Index < Low Quartile 2 ) } \\
\hline Tobin's Q & 768 & 1.907 & 1.3072 & 778 & 1.6062 & 0.8692 & $<.0001$ \\
\hline Options & 768 & 0.262 & 0.2783 & 778 & 0.2203 & 0.2444 & 0.0018 \\
\hline PPE & 768 & 0.2757 & 0.2475 & 778 & 0.3085 & 0.2575 & 0.0107 \\
\hline Foreign Income & 768 & 0.0241 & 0.0466 & 778 & 0.022 & 0.0379 & 0.3402 \\
\hline Size & 768 & $27,333.1$ & $52,442.2$ & 778 & $14,311.7$ & $19,981.1$ & $<.0001$ \\
\hline Risk & 768 & 0.1079 & 0.0579 & 778 & 0.1016 & 0.0476 & 0.0184 \\
\hline Growth & 768 & 0.1352 & 0.2002 & 778 & 0.0824 & 0.1368 & $<.0001$ \\
\hline Leverage & 768 & 0.2623 & 0.203 & 778 & 0.2443 & 0.1399 & 0.0431 \\
\hline NOL & 768 & 0.3411 & 0.4744 & 778 & 0.4293 & 0.4953 & 0.0004 \\
\hline Intang & 768 & 0.1572 & 0.2394 & 778 & 0.1782 & 0.1864 & 0.0547 \\
\hline Firm Age & 768 & 3.2372 & 0.8029 & 778 & 3.3938 & 0.74 & $<.0001$ \\
\hline Cash & 768 & 0.132 & 0.1517 & 778 & 0.0898 & 0.1005 & $<.0001$ \\
\hline Appreciation & 768 & 1.4484 & 36.7548 & 778 & 0.1028 & 0.7445 & 0.3075 \\
\hline CETR3 & 768 & $24.76 \%$ & 0.1417 & 778 & $25.55 \%$ & 0.1404 & 0.2716 \\
\hline CETR AVOID3 & 768 & $10.24 \%$ & 0.1417 & 778 & $9.45 \%$ & 0.1404 & 0.2716 \\
\hline STOCK AVOID3 & 768 & $2.85 \%$ & 0.067 & 778 & $1.81 \%$ & 0.0428 & 0.0003 \\
\hline DEPR AVOID3 & 768 & $2.90 \%$ & 0.2093 & 778 & $3.24 \%$ & 0.1641 & 0.7181 \\
\hline RESIDUAL AVOID3 BS & 768 & $1.36 \%$ & 0.0498 & 778 & $1.91 \%$ & 0.048 & 0.0256 \\
\hline RESIDUAL AVOID3 KRUL & 768 & $0.87 \%$ & 0.0427 & 778 & $1.31 \%$ & 0.0396 & 0.0353 \\
\hline OTHER AVOID3 BS & 768 & $3.32 \%$ & 0.2442 & 778 & $2.75 \%$ & 0.209 & 0.6193 \\
\hline OTHER AVOID3 KRULL & 768 & $3.81 \%$ & 0.2432 & 778 & $3.33 \%$ & 0.2099 & 0.6794 \\
\hline
\end{tabular}


Table 6

\begin{tabular}{|c|c|c|c|c|c|c|c|c|}
\hline \multicolumn{9}{|c|}{$\begin{array}{c}\text { Table } 6 \\
\end{array}$} \\
\hline \multicolumn{9}{|c|}{ Firm Value Baseline Model } \\
\hline \multicolumn{9}{|c|}{ Firm Value $_{i t}=\beta_{0}+\beta_{1}$ AVOID CETR $_{\text {it }}+\sum$ Control Variables ${ }_{\text {it }}+\varepsilon_{\text {it }}$} \\
\hline & \multicolumn{4}{|c|}{ Panel A: All Observations } & \multicolumn{4}{|c|}{$\begin{array}{c}\text { Panel B: Reduced Observations } \\
\end{array}$} \\
\hline & \multicolumn{2}{|c|}{1 year CETR } & \multicolumn{2}{|c|}{3 year CETR } & \multicolumn{2}{|c|}{1 year CETR } & \multicolumn{2}{|c|}{3 year CETR } \\
\hline & \multicolumn{8}{|c|}{ DV $=$ Tobin's Q } \\
\hline & $\mathrm{N}=4410$ & & $\mathrm{~N}=3945$ & & $\mathrm{~N}=3273$ & & $\mathrm{~N}=2612$ & \\
\hline & Coeff. & Significance & Coeff. & Significance & Coeff. & Significance & Coeff. & Significance \\
\hline$\beta_{0}$ & 1.438 & 0.0008 & 1.788 & $<.0001$ & 1.318 & 0.0076 & 1.849 & $<.0001$ \\
\hline AVOID CETR & 0.281 & 0.05 & 0.256 & 0.0766 & 0.231 & 0.1668 & 0.257 & 0.0995 \\
\hline Options & 1.069 & $<.0001$ & 0.883 & $<.0001$ & 1.123 & $<.0001$ & 0.890 & $<.0001$ \\
\hline PPE & -0.126 & 0.4386 & -0.168 & 0.3445 & 0.042 & 0.79 & 0.033 & 0.8318 \\
\hline Foreign Income & 5.585 & 0.0049 & 6.104 & $<.0001$ & 7.371 & 0.0028 & 8.960 & $<.0001$ \\
\hline Size & -0.00 & 0.5361 & -0.00 & 0.3204 & -0.00 & 0.6035 & -0.00 & 0.1528 \\
\hline Risk & -0.137 & 0.1373 & -1.966 & $<.0001$ & -1.304 & 0.2971 & -2.039 & $<.0001$ \\
\hline Growth & 0.759 & 0.2051 & 0.317 & 0.0264 & 0.889 & 0.228 & 0.361 & 0.0212 \\
\hline Leverage & -0.610 & 0.0152 & -0.454 & 0.0362 & -0.431 & 0.1227 & -0.338 & 0.1795 \\
\hline NOL & -0.086 & 0.2593 & -0.083 & 0.1298 & -0.110 & 0.2455 & -0.129 & 0.0423 \\
\hline Intang & -0.635 & 0.0001 & -0.432 & 0.0016 & -0.622 & 0.0007 & -0.432 & 0.0009 \\
\hline Firm Age & -0.020 & 0.6427 & -0.028 & 0.3906 & -0.034 & 0.5504 & -0.066 & 0.1017 \\
\hline Cash & 4.340 & 0.0019 & 2.461 & $<.0001$ & 4.636 & 0.0063 & 2.312 & $<.0001$ \\
\hline Appreciation & -0.00 & 0.3647 & -0.001 & 0.0022 & -0.001 & 0.3127 & -0.001 & 0.0346 \\
\hline Industry Dummies & Yes & & Yes & & Yes & & Yes & \\
\hline Year Dummies & Yes & & Yes & & Yes & & Yes & \\
\hline $\mathrm{R}$ & $32.31 \%$ & & $44.95 \%$ & & $32.30 \%$ & & $47.49 \%$ & \\
\hline R Adj & $31.76 \%$ & & $44.47 \%$ & & $31.59 \%$ & & $47.25 \%$ & \\
\hline
\end{tabular}

This table presents results of a baseline firm value model. See Appendix A and prior tables for variable description. Sample Period: 1 year CETR 1998-2010. 3 year CETR 2000-2010. P-values reflect clustering of standard errors at firm level. Panel A includes all observations with necessary data to calculate AVOID CETR and control variables and removal of observations missing total assets, foreign firms and cash effective tax rate less than 0 or greater than 1. Panel B includes all observations with necessary data to calculate all avoidance variables (OTHER AVOID, STOCK AVOID, DEPR AVOID and RESIDUAL AVOID) and control variables and removal of observations missing total assets, foreign firms, observations with cash effective tax rate less than 0 or greater than 1, firms reporting "amount not disclosed" for PRE and firms not reporting stock option expense after 2005. 
Table 7A

Firm Value and Alternative Methods of Tax Avoidance Model

Firm Value $_{i t}=\beta_{0}+\beta_{1}$ OTHER AVOID $_{\text {it }}+$ B $_{2}$ STOCK AVOID $_{i t}+\beta_{3}$ DEPR AVOID $_{\text {it }}+\beta_{4}$ RESIDUAL AVOID $_{\text {it }}+\sum$ Control Variables $_{\text {it }}+\varepsilon_{\mathrm{it}}$

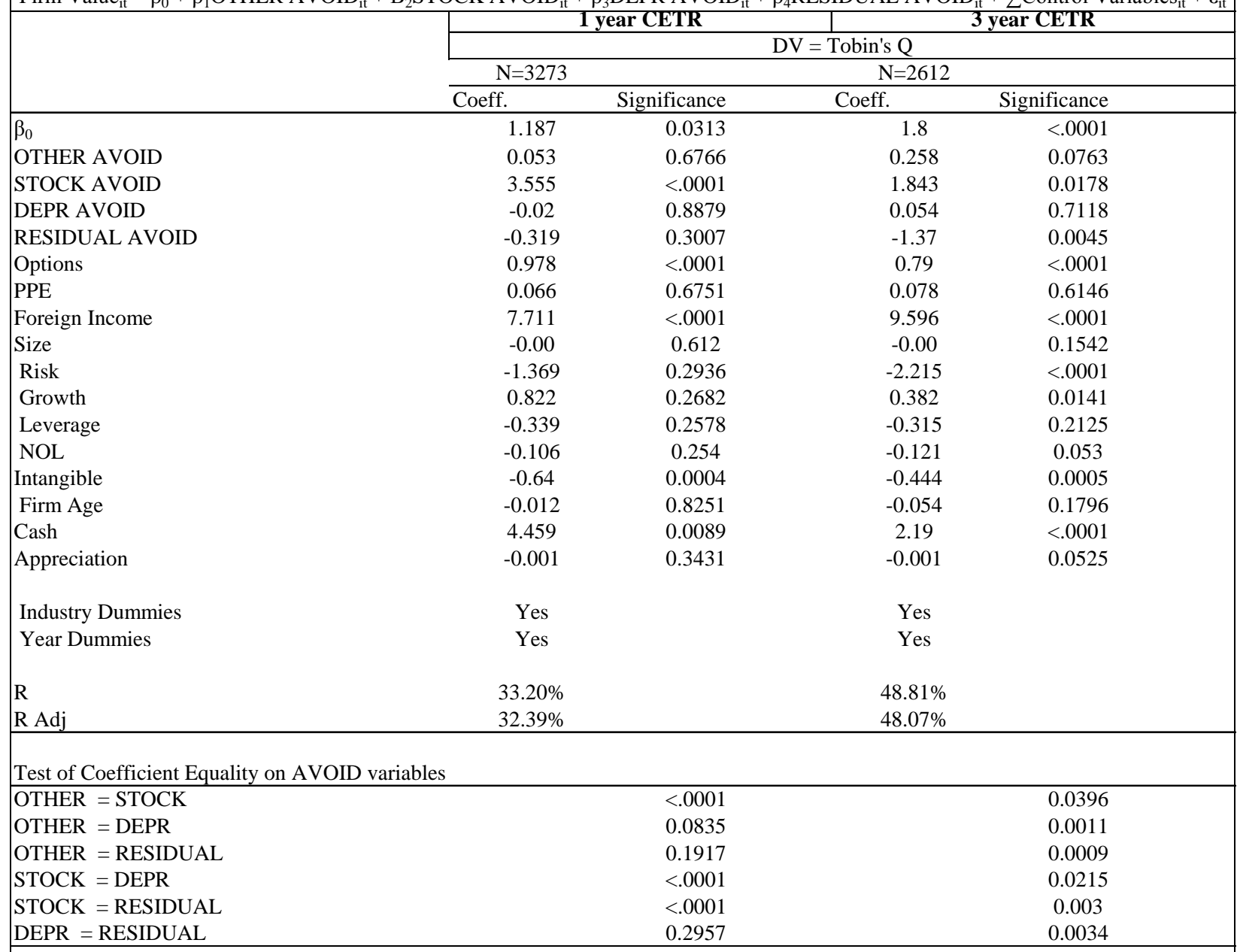

This table presents results of firm value and alternative methods of tax avoidance Model 6. See Appendix A for variable description. Sample Period: 1 year CETR 1998-2010. 3 year CETR 2000-2010. P-values reflect clustering of standard errors at firm level. Variables ending in "3" are cumulative three-year measures. STOCK AVOID(3): Tax avoidance resulting from stock option tax benefits = Option Tax Benefit/Earnings before tax and special items. DEPR AVOID(3): Tax avoidance resulting from accelerated tax depreciation deductions $=\triangle$ DTL PPE/Earnings before tax and special items. RESIDUAL AVOID(3): Tax avoidance resulting from deferral of residual U.S. tax on foreign income $=(\triangle$ PRETAX $+\Delta$ DTL unremitted foreign earnings $) /$ Earnings before tax and special items. PRETAX - Estimate based on Bauman and Shaw (2008) estimation method. OTHER AVOID(3): Tax avoidance unrelated to specific methods of tax avoidance $=35 \%$-adjusted CETR. Tobin's Q: Ratio of market value of firm to book value of firm $=((\mathrm{AT})+$ $\left.\left(\left(\mathrm{PRCC} \_\mathrm{C}\right) *(\mathrm{CSHO})\right)-(\mathrm{CEQ})\right) /(\mathrm{AT})$. Options: Average annual value realized from the exercise of options for the top five executives of options by the top five executives grossed up by the fraction of options owned by the covered executives in year t-1 (Execucomp). PPE: Property, plant and equipment, gross $=($ PPEGT/ ATt-1). Foreign Income: Pre-tax income from foreign operations $=($ PIFO/ATt-1). Size: Total Sales (SALE). Risk: Standard deviation of monthly stock returns over previous 36 months (CRSP). Growth: 3 year average sales growth from $\mathrm{t}-2$ to $\mathrm{t}=\sum \mathrm{t}-2, \mathrm{t}(\mathrm{SALEt}-\mathrm{SALEt}-1) / \mathrm{SALEt}-1$. Leverage: Long-term Debt $=(\mathrm{DLTT}+\mathrm{DLC}) /(\mathrm{AT}) . \mathrm{NOL}: \mathrm{NOL}$

Carryforward/Total Assets $=($ TLCF/AT $)$. Intangible: Intangible assets $=($ INTAN/ATt-1 $)$. Firm Age: $\operatorname{Ln}(1+$ number of years listed in Compustat). Cash: Total Cash $=(\mathrm{CHE} / \mathrm{ATt}-1)$. Appreciation: cumulative stock price appreciation over prior four years $=($ Price $\mathrm{t}-1-$ Price t-3)/ Price t-3. Industry controls based on Barth, Cram and Nelson (2001) and Rees and Sivaramakrishnan (2007). 
Table 7B Firm Value and Alternative Methods of Tax Avoidance Model - Krull PRE TAX Estimation

Firm Value $_{i t}=\beta_{0}+\beta_{1}$ OTHER AVOID $_{i t}+$ B $_{2}$ STOCK AVOID $_{i t}+\beta_{3}$ DEPR AVOID $_{i t}+\beta_{4}$ RESIDUAL AVOID $_{i t}+\sum$ Control Variables $_{\text {it }}+\varepsilon_{i t}$

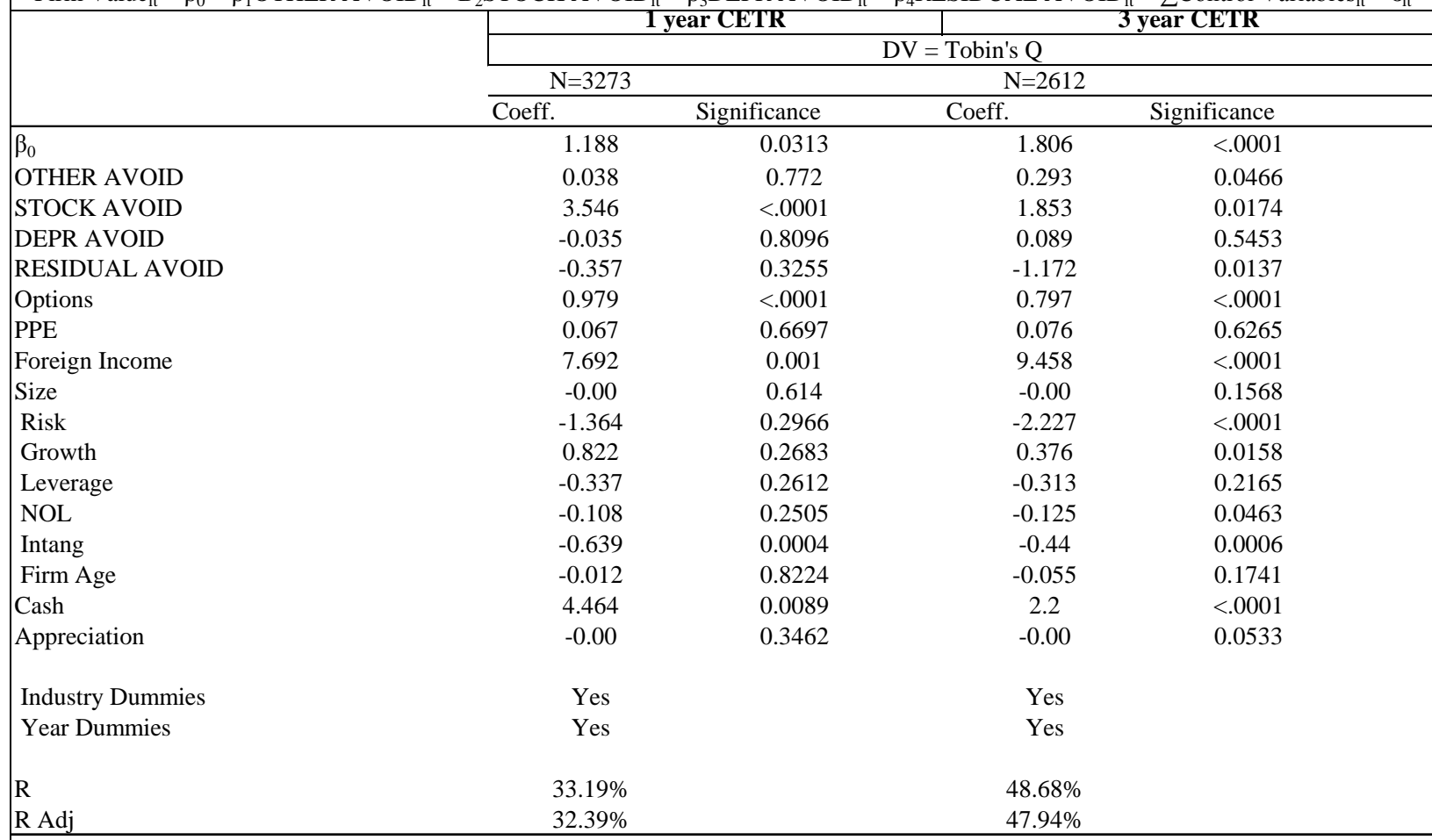

Test of Coefficient Equality on AVOID variables

\begin{tabular}{|lrr|} 
Test of Coefficient Equality on AVOID variables & & 0.0416 \\
\hline OTHER = STOCK & $<.0001$ & 0.0012 \\
OTHER = DEPR & 0.0776 & 0.0025 \\
OTHER = RESIDUAL & 0.2358 & 0.0229 \\
STOCK = DEPR & $<.0001$ & 0.0052 \\
STOCK = RESIDUAL & $<.0001$ & 0.0092 \\
DEPR = RESIDUAL & 0.3322 &
\end{tabular}

This table presents results of a firm value and alternative methods of tax avoidance Model 6. See Appendix A for variable description. Sample Period: 1 year CETR 1998-2010. 3 year CETR 2000-2010. P-values reflect clustering of standard errors at firm level. Variables ending in "3" are cumulative three-year measures. STOCK AVOID(3): Tax avoidance resulting from stock option tax benefits = Option Tax Benefit/Earnings before tax and special items. DEPR AVOID(3): Tax avoidance resulting from accelerated tax depreciation deductions = $\triangle$ DTL PPE/Earnings before tax and special items. RESIDUAL AVOID(3): Tax avoidance resulting from deferral of residual U.S. tax on foreign income $=(\Delta$ PRETAX $+\Delta$ DTL unremitted foreign earnings $) /$ Earnings before tax and special items. PRETAX - Estimate based on Krull (2004) estimation method. OTHER AVOID(3): Tax avoidance unrelated to specific methods of tax avoidance $=35 \%$-adjusted CETR. Tobin's Q: Ratio of market value of firm to book value of firm $=\left((\mathrm{AT})+\left(\left(\mathrm{PRCC} \_\mathrm{C}\right) *(\mathrm{CSHO})\right)-(\mathrm{CEQ})\right) /(\mathrm{AT})$. Options: Average annual value realized from the exercise of options for the top five executives of options by the top five executives grossed up by the fraction of options owned by the covered executives in year t-1 (Execucomp). PPE: Property, plant and equipment, gross $=($ PPEGT/ ATt-1). Foreign Income: Pre-tax income from foreign operations $=(\mathrm{PIFO} / \mathrm{ATt}-1)$. Size: Total Sales (SALE). Risk: Standard deviation of monthly stock returns over previous 36 months (CRSP). Growth: 3 year average sales growth from $\mathrm{t}-2 \mathrm{to} t=\sum \mathrm{t}-2, \mathrm{t}$ (SALEt $\left.-\mathrm{SALEt}-1\right) / \mathrm{SALEt}-1$.

Leverage: Long-term Debt $=(\mathrm{DLTT}+\mathrm{DLC}) /(\mathrm{AT})$. NOL: NOL Carryforward/Total Assets $=(\mathrm{TLCF} / \mathrm{AT})$. Intangible: Intangible assets $=$ (INTAN/ATt-1). Firm Age: $\operatorname{Ln}(1+$ number of years listed in Compustat $)$. Cash: Total Cash $=(\mathrm{CHE} / \mathrm{ATt}-1)$. Appreciation: cumulative stock price appreciation over prior four years $=($ Price t-1- Price t-3)/ Price t-3. Industry controls based on Barth, Cram and Nelson (2001) and Rees and Sivaramakrishnan (2007). 
Table 8

\begin{tabular}{|c|c|c|c|c|}
\hline \multicolumn{5}{|c|}{ Table 8} \\
\hline \multicolumn{5}{|c|}{ Firm Value and Alternative Methods of Tax Avoidance Model including Tax Haven Interaction } \\
\hline \multicolumn{5}{|c|}{$\begin{array}{c}\text { Firm Value }_{i t}=\beta_{0}+\beta_{1} \text { OTHER AVOID }_{i t}+\text { B }_{2} \text { STOCK AVOID }_{i t}+\beta_{3} \text { DEPR AVOID }_{i t}+\beta_{4} \text { RESIDUAL AVOID }_{i t}+ \\
\beta_{5} \text { RESIDUAL AVOID }_{\text {it }} * \text { Haven }_{i t}+\sum_{\text {Control Variables }}+\varepsilon_{i t}\end{array}$} \\
\hline & \multirow{2}{*}{\multicolumn{4}{|c|}{\begin{tabular}{l|l}
1 year CETR & 3 year CETR \\
\end{tabular}}} \\
\hline & & & & \\
\hline & \multicolumn{4}{|c|}{$\mathrm{N}=2612$} \\
\hline & Coeff. & Significance & Coeff. & Significance \\
\hline$\beta_{0}$ & 1.218 & 0.0225 & 1.81 & $<.0001$ \\
\hline OTHER AVOID & 0.061 & 0.6362 & 0.263 & 0.0693 \\
\hline STOCK AVOID & 3.583 & $<.0001$ & 1.853 & 0.0178 \\
\hline DEPR AVOID & -0.008 & 0.9581 & 0.059 & 0.6831 \\
\hline RESIDUAL AVOID & -0.545 & 0.1515 & -1.111 & 0.2118 \\
\hline RESIDUAL AVOID*HAVEN & 0.325 & 0.4507 & -0.388 & 0.6981 \\
\hline TAX HAVEN & -0.088 & 0.2807 & -0.028 & 0.5781 \\
\hline Options & 0.989 & $<.0001$ & 0.787 & $<.0001$ \\
\hline PPE & 0.064 & 0.685 & 0.077 & 0.6204 \\
\hline Foreign Income & 7.797 & 0.0008 & 9.619 & $<.0001$ \\
\hline Size & -.000 & 0.6192 & -.000 & 0.1519 \\
\hline Risk & -1.318 & 0.3215 & -2.201 & $<.0001$ \\
\hline Growth & 0.825 & 0.2672 & 0.383 & 0.014 \\
\hline Leverage & -0.353 & 0.2418 & -0.318 & 0.2079 \\
\hline NOL & -0.109 & 0.2459 & -0.123 & 0.0497 \\
\hline Intangible & -0.621 & 0.0005 & -0.438 & 0.0007 \\
\hline Firm Age & -0.014 & 0.8018 & -0.055 & 0.172 \\
\hline Cash & 4.446 & 0.0087 & 2.184 & $<.0001$ \\
\hline Appreciation & -0.001 & 0.3482 & -0.001 & 0.0555 \\
\hline Industry Dummies & Yes & & Yes & \\
\hline Year Dummies & Yes & & Yes & \\
\hline $\mathrm{R}$ & $33.24 \%$ & & $48.83 \%$ & \\
\hline R Adj & $32.39 \%$ & & $48.06 \%$ & \\
\hline \multicolumn{5}{|c|}{ Test of Coefficient Equality on AVOID variables } \\
\hline RESIDUAL AVOID + RESIDU & X HAVEN $=0$ & 0.5335 & & 0.003 \\
\hline \multicolumn{5}{|c|}{ 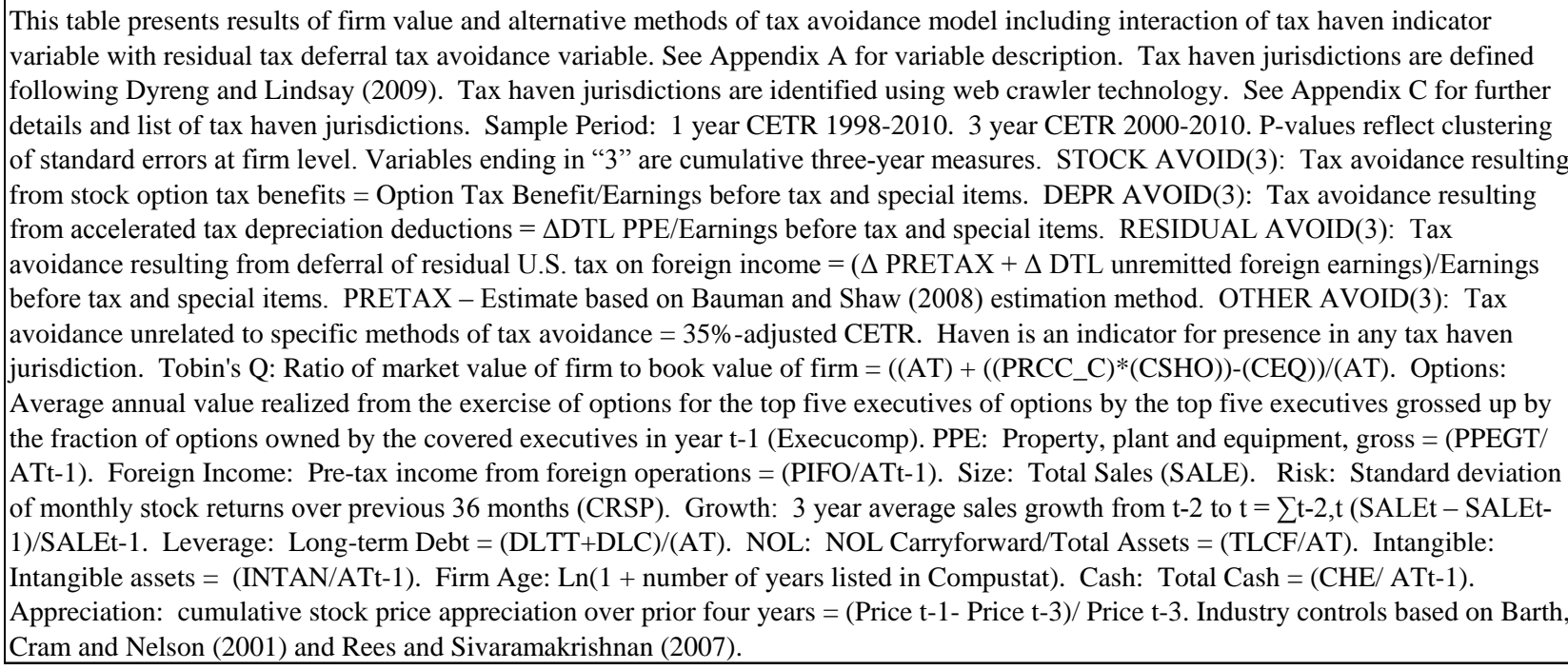 } \\
\hline
\end{tabular}


Table 9A

Firm Value and Alternative Methods of Tax Avoidance Model

Expansion of Residual Tax Deferral

Firm Value $_{\mathrm{it}}=\beta_{0}+$ B $_{1}$ OTHER AVOID $_{\mathrm{it}}+\beta_{2}$ STOCKAVOID $_{\mathrm{it}}+\beta_{3}$ DEPR AVOID $_{\mathrm{it}}+\beta_{4}$ PROVIDE AVOID $_{\mathrm{it}}+\beta_{5}$ PRETAX DISCLOSE AVOID $_{\mathrm{it}}+$ $\beta_{6}$ PRETAX ESTIMATE AVOID $_{\mathrm{it}}+\sum$ Control Variables ${ }_{\mathrm{it}}+\varepsilon_{\mathrm{it}}$

\begin{tabular}{|c|c|c|c|c|}
\hline & \multicolumn{2}{|c|}{1 year CETR } & \multicolumn{2}{|c|}{3 year CETR } \\
\hline & \multicolumn{4}{|c|}{$\mathrm{DV}=$ Tobin's $\mathrm{Q}$} \\
\hline & $\mathrm{N}=3273$ & & $\mathrm{~N}=2612$ & \\
\hline & Coeff. & Significance & Coeff. & Significance \\
\hline$\beta_{0}$ & 1.191 & 0.0308 & 1.809 & $<.0001$ \\
\hline OTHER AVOID & 0.072 & 0.5503 & 0.346 & 0.0171 \\
\hline STOCK AVOID & 3.586 & $<.0001$ & 1.881 & 0.0182 \\
\hline DEPR AVOID & -0.0004 & 0.9975 & 0.131 & 0.3637 \\
\hline PROVIDE AVOID & -0.845 & 0.2576 & -1.616 & 0.0838 \\
\hline PRETAX DISCLOSE AVOID & -0.555 & 0.269 & -1.712 & 0.0474 \\
\hline PRETAX ESTIMATE AVOID & -0.349 & 0.2758 & -0.339 & 0.2609 \\
\hline Options & 0.974 & $<.0001$ & 0.796 & $<.0001$ \\
\hline PPE & 0.072 & 0.6511 & 0.084 & 0.5929 \\
\hline Foreign Income & 7.649 & 0.0012 & 9.326 & $<.0001$ \\
\hline Size & -0.00 & 0.6448 & -0.00 & 0.1776 \\
\hline Risk & -1.402 & 0.284 & -2.197 & $<.0001$ \\
\hline Growth & 0.825 & 0.2672 & 0.373 & 0.016 \\
\hline Leverage & -0.344 & 0.2535 & -0.324 & 0.2032 \\
\hline NOL & -0.107 & 0.2489 & -0.123 & 0.0511 \\
\hline Intang & -0.631 & 0.0005 & -0.441 & 0.0007 \\
\hline Firm Age & -0.014 & 0.7941 & -0.057 & 0.1582 \\
\hline Cash & 4.461 & 0.0088 & 2.182 & $<.0001$ \\
\hline Appreciation & -0.001 & 0.3256 & -0.001 & 0.0464 \\
\hline Industry Dummies & Yes & & Yes & \\
\hline Year Dummies & Yes & & Yes & \\
\hline $\mathrm{R}$ & $33.24 \%$ & & $48.70 \%$ & \\
\hline R Adj & $32.39 \%$ & & $47.92 \%$ & \\
\hline
\end{tabular}

Test of Coefficient Equality on AVOID variables

PROVIDE = PRETAX DISCLOSE

PROVIDE $=$ PRETAX ESTIMATE

PRETAX DISCLOSE $=$ PRETAX ESTIMATE

0.7222

$0.7222-0.9406$

OTHER $=$ PROVIDE

OTHER $=$ PRETAX DISCLOSE

OTHER $=$ PRETAX ESTIMATE

0.4901

0.9406

0.6814

0.1847
0.103

0.2007

0.2099

0.1939

0.0371

STOCK $=$ PROVIDE

STOCK $=$ PRETAX DISCLOSE

$<.0001$

0.0186

$<.0001$

0.0396

STOCK $=$ PRETAX ESTIMATE

$<.0001$

0.2345

DEPR $=$ PRETAX DISCLOSE

0.2676

DEPR $=$ PRETAX ESTIMATE

0.2833

0.0198

0.0071

0.0112

0.0631

0.035

This table presents results of firm value and alternative methods of tax avoidance Mode 7 including the expansion of RESIDUAL AVOID(3) into the three methods of disclosing residual tax deferral. See Appendix A for variable description. Sample Period: 1 year CETR 1998-2010. 3 year CETR 2000-2010. Pvalues reflect clustering of standard errors at firm level. Variables ending in "3" are cumulative three-year measures. STOCK AVOID(3): Tax avoidance resulting from stock option tax benefits = Option Tax Benefit/Earnings before tax and special items. DEPR AVOID(3): Tax avoidance resulting from accelerated tax depreciation deductions $=\triangle \mathrm{DTL}$ PPE/Earnings before tax and special items. PROVIDE AVOID(3): Tax avoidance related to provision of deferred tax expense on unrepatriated foreign earnings. PRETAX DISCLOSE AVOID(3): Tax avoidance related to disclosed unrecognized tax liability on unrepatriated foreign earnings. PRETAX ESTIMATE AVOID(3): Tax avoidance related to estimated unrecognized tax liability on unrepatriated foreign earnings. PRETAX Estimate based on Bauman and Shaw (2008) estimation method. OTHER AVOID(3): Tax avoidance unrelated to specific methods of tax avoidance = 35\%adjusted CETR. Tobin's Q: Ratio of market value of firm to book value of firm $=\left((\mathrm{AT})+\left(\left(\mathrm{PRCC} \_\mathrm{C}\right) *(\mathrm{CSHO})\right)-(\mathrm{CEQ})\right) /(\mathrm{AT})$. Options: Average annual value realized from the exercise of options for the top five executives of options by the top five executives grossed up by the fraction of options owned by the covered executives in year t-1 (Execucomp). PPE: Property, plant and equipment, gross $=($ PPEGT/ ATt-1). Foreign Income: Pre-tax income from foreign operations $=$ (PIFO/ATt-1). Size: Total Sales (SALE). Risk: Standard deviation of monthly stock returns over previous 36 months (CRSP). Growth: 3 year average sales growth from $\mathrm{t}-2$ to $\mathrm{t}=\sum \mathrm{t}-2, \mathrm{t}(\mathrm{SALEt}-\mathrm{SALEt}-1) / \mathrm{SALEt}-1$. Leverage: Long-term Debt $=(\mathrm{DLTT}+\mathrm{DLC}) /(\mathrm{AT})$. NOL: NOL Carryforward/Total Assets $=$ $(\mathrm{TLCF} / \mathrm{AT})$. Intangible: Intangible assets $=($ INTAN/ATt-1 $)$. Firm Age: $\operatorname{Ln}(1+$ number of years listed in Compustat $)$. Cash: Total Cash $=(\mathrm{CHE} / \mathrm{ATt}-1)$. Appreciation: cumulative stock price appreciation over prior four years $=($ Price t-1- Price t-3)/ Price t-3. Industry controls based on Barth, Cram and Nelson (2001) and Rees and Sivaramakrishnan (2007). 
Table 9B

Firm Value and Alternative Methods of Tax Avoidance Model - Krull PRE TAX Estimation Expansion of Residual Tax Deferral

Firm Value $_{i t}=\beta_{0}+$ B OTHER AVOID $_{1}+\beta_{2}$ STOCKAVOID $_{i t}+\beta_{3}$ DEPR AVOID $_{i t}+\beta_{4}$ PROVIDE AVOID $_{i t}+\beta_{5}$ PRETAX DISCLOSE AVOID $_{\text {it }}+$ $\beta_{6}$ PRETAX ESTIMATE AVOID $_{\mathrm{it}}+\sum$ Control Variables $\mathrm{it}_{\mathrm{it}}+\varepsilon_{\mathrm{it}}$

$\beta_{0}$

OTHER AVOID

STOCK AVOID

DEPR AVOID

PROVIDE AVOID

PRETAX DISCLOSE AVOID

PRETAX ESTIMATE AVOID

Options

PPE

Foreign Income

Size

Risk

Growth

Leverage

NOL

Intang

Firm Age

Cash

Appreciation

Industry Dummies

Year Dummies

$\mathrm{R}$

R Adj

\begin{tabular}{|c|c|c|c|}
\hline \multicolumn{2}{|c|}{1 year CETR } & \multicolumn{2}{|c|}{3 year CETR } \\
\hline \multicolumn{4}{|c|}{$\mathrm{DV}=$ Tobin's $\mathrm{Q}$} \\
\hline $\mathrm{N}=3273$ & & $\mathrm{~N}=2612$ & \\
\hline Coeff. & Significance & Coeff. & Significance \\
\hline 1.192 & 0.0307 & 1.809 & $<.0001$ \\
\hline 0.0646 & 0.6048 & 0.349 & 0.0169 \\
\hline 3.583 & $<.0001$ & 1.884 & 0.0178 \\
\hline-0.009 & 0.946 & 0.135 & 0.3528 \\
\hline-0.861 & 0.2553 & -1.597 & 0.0867 \\
\hline-0.5304 & 0.2893 & -1.721 & 0.0455 \\
\hline-0.326 & 0.3793 & -0.374 & 0.2526 \\
\hline 0.975 & $<.0001$ & 0.798 & $<.0001$ \\
\hline 0.0715 & 0.6513 & 0.085 & 0.5891 \\
\hline 7.62 & 0.0013 & 9.284 & $<.0001$ \\
\hline-0.00 & 0.646 & -0.00 & 0.1798 \\
\hline-1.396 & 0.2858 & -2.2 & $<.0001$ \\
\hline 0.824 & 0.2674 & 0.372 & 0.0163 \\
\hline-0.342 & 0.2563 & -0.321 & 0.2073 \\
\hline-0.108 & 0.2456 & -0.126 & 0.0465 \\
\hline-0.631 & 0.0005 & -0.439 & 0.0007 \\
\hline-0.0144 & 0.7942 & -0.058 & 0.1561 \\
\hline 4.463 & 0.0088 & 2.188 & $<.0001$ \\
\hline-0.001 & 0.3298 & -0.001 & 0.047 \\
\hline Yes & & Yes & \\
\hline Yes & & Yes & \\
\hline $33.22 \%$ & & $48.49 \%$ & \\
\hline $32.38 \%$ & & $47.73 \%$ & \\
\hline
\end{tabular}

Test of Coefficient Equality on AVOID variables

PROVIDE = PRETAX DISCLOSE

PROVIDE $=$ PRETAX ESTIMATE

PRETAX DISCLOSE $=$ PRETAX ESTIMATE

OTHER $=$ PROVIDE

OTHER $=$ PRETAX DISCLOSE

OTHER $=$ PRETAX ESTIMATE

STOCK $=$ PROVIDE

STOCK $=$ PRETAX DISCLOSE

STOCK $=$ PRETAX ESTIMATE

DEPR $=$ PROVIDE

DEPR $=$ PRETAX DISCLOSE

DEPR $=$ PRETAX ESTIMATE

$\begin{array}{ll}0.7029 & 0.9234 \\ 0.4825 & 0.2107 \\ 0.6925 & 0.1093 \\ 0.2034 & 0.0378 \\ 0.2379 & 0.0173 \\ 0.3202 & 0.0465 \\ <.0001 & 0.0199 \\ <.0001 & 0.0066 \\ <.0001 & 0.0106 \\ 0.2387 & 0.0643 \\ 0.3016 & 0.0328 \\ 0.4212 & 0.1572\end{array}$

This table presents results of firm value and alternative methods of tax avoidance Model 7 including the expansion of RESIDUAL AVOID(3) into the three methods of disclosing residual tax deferral. See Appendix A for variable description. Sample Period: 1 year CETR 1998-2010. 3 year CETR 2000-2010. Pvalues reflect clustering of standard errors at firm level. Variables ending in " 3 " are cumulative three-year measures. STOCK AVOID(3): Tax avoidance resulting from stock option tax benefits = Option Tax Benefit/Earnings before tax and special items. DEPR AVOID(3): Tax avoidance resulting from accelerated tax depreciation deductions $=\triangle \mathrm{DTL}$ PPE/Earnings before tax and special items. PROVIDE AVOID(3): Tax avoidance related to provision of deferred tax expense on unrepatriated foreign earnings. PRETAX DISCLOSE AVOID(3): Tax avoidance related to disclosed unrecognized tax liability on unrepatriated foreign earnings. PRETAX ESTIMATE AVOID(3): Tax avoidance related to estimated unrecognized tax liability on unrepatriated foreign earnings. PRETAX - Estimate based on Krull (2004) estimation method. OTHER AVOID(3): Tax avoidance unrelated to specific methods of tax avoidance $=35 \%$-adjusted CETR. Tobin's Q: Ratio of market value of firm to book value of firm $=\left((\mathrm{AT})+\left(\left(\mathrm{PRCC} \_\mathrm{C}\right) *(\mathrm{CSHO})\right)-(\mathrm{CEQ})\right) /(\mathrm{AT})$. Options: Average annual value realized from the exercise of options for the top five executives of options by the top five executives grossed up by the fraction of options owned by the covered executives in year t-1 (Execucomp). PPE: Property, plant and equipment, gross $=($ PPEGT/ ATt-1). Foreign Income: Pre-tax income from foreign operations $=(\mathrm{PIFO} / \mathrm{ATt}-1)$. Size: Total Sales $($ SALE). Risk: Standard deviation of monthly stock returns over previous 36 months $\left(\right.$ CRSP). Growth: 3 year average sales growth from $t-2$ to $t=\sum t-2, t($ SALEt - SALEt-1)/SALEt-1. Leverage: Long-term Debt $=($ DLTT + DLC $) /(A T)$. NOL: NOL Carryforward/Total Assets $=($ TLCF/AT $)$. Intangible: Intangible assets $=($ INTAN/ATt-1). Firm Age: $\operatorname{Ln}(1+$ number of years listed in Compustat $)$. Cash: Total Cash $=(\mathrm{CHE} / \mathrm{ATt}-1)$. Appreciation: cumulative stock price appreciation over prior four years $=($ Price $\mathrm{t}-1-$ Price $\mathrm{t}-3) /$ Price $\mathrm{t}-3$. Industry controls based on Barth, Cram and Nelson (2001) and Rees and Sivaramakrishnan (2007). 
Table 10A

Firm Value and Governance Baseline Models - G-Index

Firm Value $_{\text {it }}=\beta_{0}+\beta_{1}$ CETR AVOID $_{\text {it }}+\beta_{2}$ CETR AVOID $_{\text {it }} *$ PoorG $_{\text {it }}+\beta_{3}$ CETR AVOID $_{\text {it }} *$ StrongG $_{\text {it }}+\sum$ Control Variables $_{\text {it }}+\varepsilon_{\text {it }}$

\begin{tabular}{|c|c|c|c|c|c|c|c|c|}
\hline \multirow[b]{3}{*}{$\mathrm{N}$} & \multicolumn{8}{|c|}{ DV $=$ Tobin's Q } \\
\hline & \multicolumn{2}{|c|}{ Panel A: PoorG @ mean } & \multicolumn{2}{|c|}{ Panel B: Poor G @ Q3 } & \multicolumn{2}{|c|}{ Panel C: Poor G @ Top Decile } & \multicolumn{2}{|c|}{ Panel D: Strong G @ Q2/Poor G @ Q3 } \\
\hline & 2,612 & & 2,612 & & 2,612 & & 2,612 & \\
\hline$\%$ of Poor Governance Firms & 1,410 & $53.98 \%$ & 663 & $25.38 \%$ & 197 & $7.54 \%$ & 663 & $25.38 \%$ \\
\hline$\%$ of Strong Governance Firms & 1,202 & $46.02 \%$ & 1,949 & $74.62 \%$ & 2,415 & $92.46 \%$ & 816 & $31.24 \%$ \\
\hline Variables & Coeff. & Significance & Coeff. & Significance & Coeff. & Significance & Coeff. & Significance \\
\hline$\beta_{0}$ & 1.863 & $<.0001$ & 1.853 & $<.0001$ & 1.851 & $<.0001$ & 1.851 & $<.0001$ \\
\hline CETR AVOID3 & 0.400 & 0.097 & 0.275 & 0.1177 & 0.245 & 0.1336 & 0.219 & 0.1592 \\
\hline CETR AVOID3*PoorG & -0.283 & 0.322 & -0.028 & 0.9301 & -0.184 & 0.613 & 0.029 & 0.9236 \\
\hline CETR AVOID $3 *$ StrongG & & & & & & & 0.142 & 0.6783 \\
\hline PoorG & -0.084 & 0.346 & -0.070 & 0.3921 & -0.049 & 0.5281 & -0.065 & 0.4122 \\
\hline StrongG & & & & & & & 0.018 & 0.8695 \\
\hline Options & 0.877 & $<.0001$ & 0.888 & $<.0001$ & 0.885 & $<.0001$ & 0.889 & $<.0001$ \\
\hline PPE & 0.055 & 0.711 & 0.031 & 0.843 & 0.030 & 0.8468 & 0.041 & 0.7892 \\
\hline Foreign Income & 8.884 & $<.0001$ & 8.958 & $<.0001$ & 8.914 & $<.0001$ & 8.948 & $<.0001$ \\
\hline SIZE & 0.000 & 0.090 & 0.000 & 0.1338 & 0.000 & 0.1361 & 0.000 & 0.1197 \\
\hline Risk & -2.109 & $<.0001$ & -2.028 & $<.0001$ & -2.071 & $<.0001$ & -2.069 & $<.0001$ \\
\hline Growth & 0.337 & 0.027 & 0.361 & 0.0215 & 0.348 & 0.0254 & 0.353 & 0.0264 \\
\hline Leverage & -0.378 & 0.123 & -0.345 & 0.1712 & -0.351 & 0.1638 & -0.353 & 0.1498 \\
\hline NOL & -0.120 & 0.052 & -0.129 & 0.0407 & -0.128 & 0.0438 & -0.126 & 0.0428 \\
\hline Intang & -0.425 & 0.001 & -0.431 & 0.0011 & -0.431 & 0.001 & -0.425 & 0.0013 \\
\hline Firm Age & -0.056 & 0.164 & -0.061 & 0.1346 & -0.064 & 0.111 & -0.061 & 0.1373 \\
\hline Cash & 2.362 & $<.0001$ & 2.255 & $<.0001$ & 2.353 & $<.0001$ & 2.200 & $<.0001$ \\
\hline Cash*PoorG & -0.218 & 0.756 & 0.240 & 0.724 & -1.297 & 0.0721 & 0.299 & 0.6459 \\
\hline Cash*StrongG & & & & & & & 0.094 & 0.9089 \\
\hline Appreciation & -0.001 & $<.0001$ & -0.001 & 0.0339 & -0.001 & 0.0362 & -0.001 & 0.0251 \\
\hline Industry Dummies & Yes & & Yes & & Yes & & Yes & \\
\hline Year Dummies & Yes & & Yes & & Yes & & Yes & \\
\hline $\mathrm{R}$ & $48.32 \%$ & & $47.98 \%$ & & $48.10 \%$ & & $37.03 \%$ & \\
\hline Adj R & $47.58 \%$ & & $47.24 \%$ & & $47.35 \%$ & & $28.01 \%$ & \\
\hline $\begin{array}{l}\text { Panel E: Test Value of Tax Avoidance in poor } \\
\text { CETRAVOID3+CETRAVOID3*PoorG }=0 \\
\text { CETRAVOID3+CETRAVOID3*StrongG }=0\end{array}$ & ned firms & 0.4984 & & 0.3721 & & 0.2025 & & $\begin{array}{l}0.3289 \\
0.0663\end{array}$ \\
\hline
\end{tabular}


Table 10A

Table Notes:

Firm Value and Governance Baseline Models - G-Index

This table presents a baseline firm value model in an agency context. See Appendix A for variable description. Sample Period: 2000-2010. P-values reflect clustering of standard errors at firm level.

Governance measured using G-Index (Gompers et al 2003). Variables reported for each of four governance assignments as described in text of paper. Governance Assignment $1 \mathrm{Mean}$ : Poor G $=\mathrm{G}-\mathrm{Index}>$

Sample Mean 9.896. Governance Assignment 2 Third Quartile: Poor G = G-Index > Sample Third Quartile 12. Governance Assignment 3 Top Decile: Poor G = G-Index > Top Decile 14. Governance

Assignment 4 Extreme Quartiles: Poor G = G-Index > TopQuartile 12 /Strong G = G-Index < Low Quartile 8. AVOID STOCK3: Tax avoidance resulting from stock option tax benefits = Option Tax

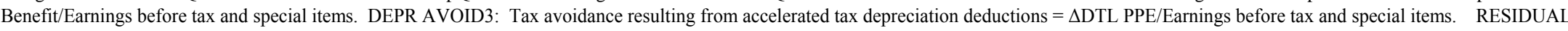

AVOID3: Tax avoidance resulting from deferral of residual U.S. tax on foreign income $=(\triangle$ PRETAX $+\Delta$ DTL unremitted foreign earnings $) /$ Earnings before tax and special items. PRETAX - Estimate based

on Bauman and Shaw (2008) estimation method. OTHER AVOID3: Tax avoidance unrelated to specific methods of tax avoidance $=35 \%$-adjusted CETR. Tobin's Q: Ratio of market value of firm to book

value of firm $=\left((\mathrm{AT})+\left(\left(\mathrm{PRCC} \_\mathrm{C}\right) *(\mathrm{CSHO})\right)-(\mathrm{CEQ})\right) /(\mathrm{AT})$. Options: Average annual value realized from the exercise of options for the top five executives of options by the top five executives grossed up by

the fraction of options owned by the covered executives in year $\mathrm{t}-1$ (Execucomp). PPE: Property, plant and equipment, gross = $($ PPEGT/ ATt-1). Foreign Income: Pre-tax income from foreign operations =

$(\mathrm{PIFO} / \mathrm{ATt}-1)$. Size: Total Sales (SALE). Risk: Standard deviation of monthly stock returns over previous 36 months $(\mathrm{CRSP})$. Growth: 3 year average sales growth from $\mathrm{t}-2$ to $\mathrm{t}=\sum \mathrm{t}-2, \mathrm{t}(\mathrm{SALEt}-\mathrm{SALEt}-$

1)/SALEt-1. Leverage: Long-term Debt $=($ DLTT+DLC $) /($ AT $)$. NOL: NOL Carryforward/Total Assets $=($ TLCF/AT $)$. Intangible: Intangible assets $=($ INTAN/ATt-1). Firm Age: Ln $(1+$ number of years

listed in Compustat). Cash: Total Cash $=(\mathrm{CHE} / \mathrm{ATt}-1)$. Appreciation: cumulative stock price appreciation over prior four years $=($ Price $\mathrm{t}-1-$ Price $\mathrm{t}-3) /$ Price $\mathrm{t}-3$. Industry controls based on Barth, Cram and

Nelson (2001) and Rees and Sivaramakrishnan (2007). 
Table 10B

Firm Value and Governance Baseline Models - E-Index

Firm Value $_{\mathrm{it}}=\beta_{0}+\beta_{1}$ CETR AVOID $_{\mathrm{it}}+\beta_{2}$ CETR AVOID $_{\mathrm{it}} *$ PoorG $_{\mathrm{it}}+\beta_{3}$ CETR AVOID $_{\mathrm{it}}$ *StrongG $_{\mathrm{it}}+\sum$ Control Variables $_{\mathrm{it}}+\varepsilon_{\mathrm{it}}$

\begin{tabular}{|l|c|c|c|c|c|c|}
\hline & DV = Tobin's Q \\
\hline $\mathrm{N}$ & Panel A: PoorG @ mean & Panel B: Poor G @ Q3 & Panel C: Poor G @ Top Decile & Panel D: Strong G @ Q2/Poor G @ Q3 \\
\cline { 2 - 4 } & 2,612 & 2,612 & 2,612
\end{tabular}

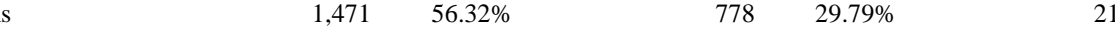

$\%$ of Strong Governance Firms

Variables

$1,141 \quad 43.68 \% \quad 1,834$

CETR AVOID3

$1.9196 \quad$ Significance

$70.21 \%$

\begin{tabular}{|c|c|}
\hline $838 \%$ & $\frac{102}{778}$ \\
\hline $8.38 \%$ & 778 \\
\hline
\end{tabular}

$1.9196<.000$

1.8891

Significance

Coeff. Significance Coeff.

$0.4413 \quad 0.0735$

$\begin{array}{ll}1.8891< & <.0001 \\ 0.2547 & 0.1683\end{array}$

$1.8427<.0001$

Coeff. Significance

CETR AVOID $3 *$ PoorG

CETR AVOID3*StrongG

PoorG

StrongG

Options

PPE

Foreign Income

SIZE

Risk

Growth

Leverage

NOL

Intang

Firm A

Cash*PoorG

Cash*StrongG

Appreciation

Industry Dummies

Year Dummies

$-0.296$

0.0036

0.1683
0.9902

0.3128

$<.0001$

$\begin{array}{ll}1.9271 & <.0001 \\ 0.1527 & 0.4184\end{array}$

$\begin{array}{ll}-0.0827 & 0.308\end{array}$

$-0.1096$

0.1955

$-0.6734$

0.1121

$\begin{array}{ll}0.1040 & 0.7281\end{array}$

$0.8660<.0001$

$0.0542 \quad 0.7249$

0.8865

$<.0001$

0.0233

$0.4156 \quad 0.3260$

0.0385
8.9373
0.0000

0.8035

0.8894

0.7995

$-0.1369$

0.3260

$\begin{array}{lll}<.0001 & 0.8817 & <.0001 \\ 0.7633 & 0.0506 & 0.7417\end{array}$

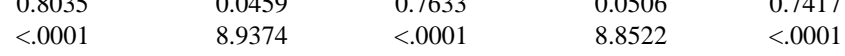

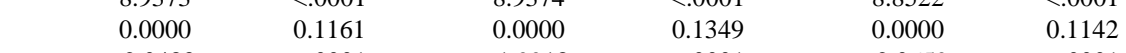

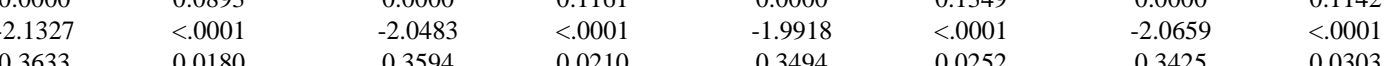

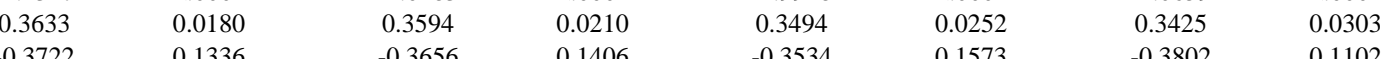

$\begin{array}{llllllll}-0.3722 & 0.1336 & -0.3656 & 0.1406 & -0.3534 & 0.1573 & -0.3802 & 0.1102 \\ -0.1229 & 0.0448 & -0.1291 & 0.0333 & -0.1269 & 0.0447 & -0.1221 & 0.0455 \\ -0.4337 & 0.0008 & -0.4388 & 0.0007 & -0.4429 & 0.0007 & -0.4200 & 0.0011\end{array}$

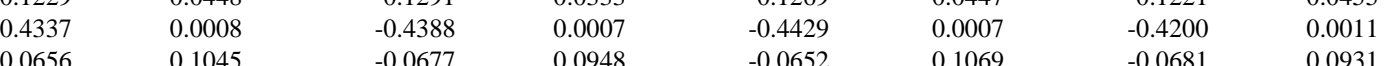

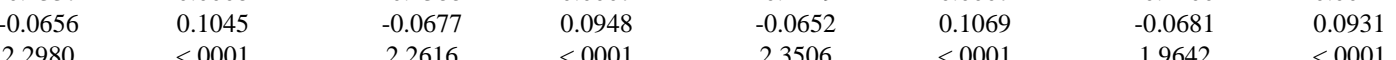

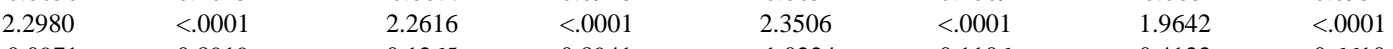

$\begin{array}{rrrrrrrr}2.2980 & <.0001 & 2.2616 & <.0001 & 2.3506 & <.0001 & 1.9642 & <.0001 \\ -0.0971 & 0.8919 & 0.1265 & 0.8941 & -1.0224 & 0.1106 & 0.4133 & 0.6610 \\ & & & & & & & 0.5844\end{array}$

$\begin{array}{llllllll}-0.0012 & 0.0243 & -0.0011 & 0.0299 & -0.0011 & 0.0320 & -0.0012 & 0.0308\end{array}$

$\begin{array}{ll}\text { Yes } & \text { Yes } \\ \text { Yes } & \text { Yes }\end{array}$

Yes

Yes

Yes

Yes

$\begin{array}{llll}48.24 \% & 48.08 \% & 48.15 \% & 48.26 \%\end{array}$

$47.49 \%$

$47.34 \%$

$47.41 \%$

$48.26 \%$

Panel E: Test Value of Tax Avoidance in poorly/strong governed firms

CETRAVOID3+CETRAVOID3*PoorG $=0$

0.4122

0.2933

0.3594

0.2922

CETRAVOID $3+$ CETRAVOID $3 *$ Strong $\mathrm{G}=0$ 
Table 10B

Table Notes

Firm Value and Governance Baseline Models - E-Index

This table presents a baseline firm value model in an agency context. See Appendix A for variable description. Sample Period: 2000-2010. P-values reflect clustering of standard errors at firm level. Governance measured using E-Index (Bebchuk et al 2005). Variables reported for each of four governance assignments as described in text of paper. Governance Assignment 1 Mean: Poor G = E-Index > Sample Mean 2.735. Governance Assignment 2 Third Quartile: Poor G = E-Index > Sample Third Quartile 4. Governance Assignment 3 Top Decile: Poor G = E-Index > Top Decile 5. Governance Assignment 4 Extreme Quartiles: Poor G = E-Index > TopQuartile 4 /Strong G = G-Index < Low Quartile 2. AVOID STOCK3: Tax avoidance resulting from stock option tax benefits = Option Tax Benefit/Earnings before tax and special items. DEPR AVOID3: Tax avoidance resulting from accelerated tax depreciation deductions $=\triangle D T L$ PPE/Earnings before tax and special items. RESIDUAL AVOID3: Tax avoidance resulting from deferral of residual U.S. tax on foreign income $=(\Delta$ PRETAX $+\Delta$ DTL unremitted foreign earnings $) /$ Earnings before tax and special items. PRETAX - Estimate based on Bauman and Shaw (2008) estimation method. OTHER AVOID3: Tax avoidance unrelated to specific methods of tax avoidance $=35 \%$-adjusted CETR. Tobin's Q: Ratio of market value of firm to book value of firm $=\left((\mathrm{AT})+\left(\left(\mathrm{PRCC} \_\mathrm{C}\right) *(\mathrm{CSHO})\right)-(\mathrm{CEQ})\right) /(\mathrm{AT})$. Options: Average annual value realized from the exercise of options for the top five executives of options by the top five executives grossed up by the fraction of options owned by the covered executives in year t-1 (Execucomp). PPE: Property, plant and equipment, gross = (PPEGT/ ATt-1). Foreign Income: Pre-tax income from foreign operations $=(\mathrm{PIFO} / \mathrm{ATt}-1)$. Size: Total Sales $(\mathrm{SALE})$. Risk: Standard deviation of monthly stock returns over previous 36 months $(\mathrm{CRSP})$. Growth: 3 year average sales growth from $\mathrm{t}-2 \mathrm{to} t=\sum \mathrm{t}$ 2,t $($ SALEt - SALEt-1)/SALEt-1. Leverage: Long-term Debt $=($ DLTT+DLC $) /($ AT $)$. NOL: NOL Carryforward/Total Assets $=($ TLCF/AT $)$. Intangible: Intangible assets $=($ INTAN/ATt-1). Firm Age: $\mathrm{Ln}(1+$ number of years listed in Compustat). Cash: Total Cash $=(\mathrm{CHE} / \mathrm{ATt}-1)$. Appreciation: cumulative stock price appreciation over prior four years $=($ Price $\mathrm{t}-1-$ Price $\mathrm{t}-3) /$ Price $\mathrm{t}-3$. Industry controls based on Barth, Cram and Nelson (2001) and Rees and Sivaramakrishnan (2007). 
Table 11A

Firm Value and Expaned Avoidance Measure Governance Models -G-Index

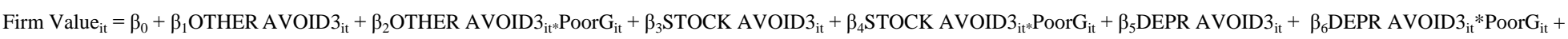

$\beta_{7}$ RESIDUAL AVOID $_{\mathrm{it}}+\beta_{8}$ RESIDUAL AVOID $_{\mathrm{it}} * \mathrm{PoorG}_{\mathrm{it}}+\sum$ Control Variables $_{\mathrm{it}}+\varepsilon_{\mathrm{it}}$

Variables

$\beta_{0}$

OTHER AVOID3

OTHER AVOID $3 *$ PoorG

OTHER AVOID $3 *$ StrongG

STOCK AVOID3

STOCK AVOID3*PoorG

STOCK AVOID $3 *$ StrongG

DEPR AVOID3

DEPR AVOID3*PoorG

DEPR AVOID $3 *$ StrongG

RESIDUAL AVOID3

RESIDUAL AVOID3*PoorG

RESIDUAL AVOID3*StrongG

PoorG

StrongG

Option

PPE

Foreign Income

SIZE

Risk

Growth

Leverage

NOL

Intang

Firm Age

Cash

Cash*PoorG

Cash*StrongG

Appreciation

Industry Dummies

Year Dummies

Adj

\begin{tabular}{|c|c|c|c|c|c|c|c|}
\hline \multicolumn{8}{|c|}{ DV = Tobin's Q } \\
\hline \multirow{2}{*}{\multicolumn{2}{|c|}{$\begin{array}{l}\text { Panel A: PoorG @ mean } \\
\mathrm{N}=2612\end{array}$}} & \multirow{2}{*}{\multicolumn{2}{|c|}{$\begin{array}{l}\text { Panel B: Poor G @ Q3 } \\
\mathrm{N}=2612\end{array}$}} & \multirow{2}{*}{\multicolumn{2}{|c|}{\begin{tabular}{|l|} 
Panel C: Poor G @ Top Decile \\
N=2612
\end{tabular}}} & \multirow{2}{*}{\multicolumn{2}{|c|}{$\begin{array}{l}\text { Panel D: Strong G @ Q2/Poor G @ Q3 } \\
\mathrm{N}=2612\end{array}$}} \\
\hline & & & & & & $\mathrm{N}=2612$ & \\
\hline Coeff. & Significance & Coeff. & Significance & Coeff. & Significance & Coeff. & Significance \\
\hline 1.8196 & $<.0001$ & 1.7890 & $<.0001$ & 1.7949 & $<.0001$ & 1.7799 & $<.0001$ \\
\hline 0.4484 & 0.0596 & 0.3218 & 0.0616 & 0.2547 & 0.0949 & 0.2757 & 0.0793 \\
\hline-0.3671 & 0.1867 & -0.3006 & 0.3266 & -0.0169 & 0.9622 & $\begin{array}{c}-0.2526 \\
0.0963\end{array}$ & $\begin{array}{l}0.3940 \\
0.7852\end{array}$ \\
\hline 2.0707 & 0.0295 & 2.1958 & 0.0170 & 1.9979 & 0.0153 & 2.3501 & 0.0303 \\
\hline-0.6066 & 0.6544 & -1.7802 & 0.1505 & -3.2238 & 0.0008 & $\begin{array}{c}-1.9052 \\
0.1285\end{array}$ & $\begin{array}{l}0.1476 \\
0.9415\end{array}$ \\
\hline 0.1803 & 0.4225 & 0.1032 & 0.5506 & 0.0352 & 0.8182 & 0.0980 & 0.5845 \\
\hline-0.2302 & 0.3942 & -0.1407 & 0.6641 & 0.3414 & 0.2352 & $\begin{array}{r}-0.1347 \\
0.0185\end{array}$ & $\begin{array}{l}0.6845 \\
0.9573\end{array}$ \\
\hline-1.2877 & 0.0592 & -1.3597 & 0.0057 & -1.4318 & 0.0053 & -1.9723 & 0.0022 \\
\hline-0.1952 & 0.8255 & 0.0199 & 0.9854 & 0.2987 & 0.7355 & $\begin{array}{l}0.6223 \\
1.3008\end{array}$ & $\begin{array}{l}0.5794 \\
0.2219\end{array}$ \\
\hline-0.0741 & 0.4010 & -0.0298 & 0.7080 & -0.0132 & 0.8578 & $\begin{array}{c}-0.0294 \\
0.0186\end{array}$ & $\begin{array}{l}0.7105 \\
0.8624\end{array}$ \\
\hline 0.7798 & $<.0001$ & 0.7817 & $<.0001$ & 0.7748 & $<.0001$ & 0.7788 & $<.0001$ \\
\hline 0.0970 & 0.5176 & 0.0755 & 0.6274 & 0.0762 & 0.6262 & 0.0894 & 0.5590 \\
\hline 9.5330 & $<.0001$ & 9.6272 & $<.0001$ & 9.5898 & $<.0001$ & 9.6506 & $<.0001$ \\
\hline 0.0000 & 0.0959 & 0.0000 & 0.1434 & 0.0000 & 0.1366 & 0.0000 & 0.1147 \\
\hline-2.3000 & $<.0001$ & -2.1779 & $<.0001$ & -2.2239 & $<.0001$ & -2.1786 & $<.0001$ \\
\hline 0.3572 & 0.0180 & 0.3898 & 0.0123 & 0.3914 & 0.0117 & 0.3758 & 0.0173 \\
\hline-0.3549 & 0.1479 & -0.3207 & 0.2063 & -0.3316 & 0.1898 & -0.3292 & 0.1844 \\
\hline-0.1122 & 0.0658 & -0.1210 & 0.0524 & -0.1202 & 0.0548 & -0.1150 & 0.0624 \\
\hline-0.4362 & 0.0007 & -0.4549 & 0.0005 & -0.4455 & 0.0005 & -0.4530 & 0.0004 \\
\hline-0.0443 & 0.2645 & -0.0469 & 0.2527 & -0.0497 & 0.2145 & -0.0445 & 0.2800 \\
\hline 2.2242 & 0.0002 & 2.0816 & $<.0001$ & 2.2061 & $<.0001$ & 1.9991 & $<.0001$ \\
\hline-0.1728 & 0.8007 & 0.3942 & 0.5625 & -1.0744 & 0.1384 & $\begin{array}{l}0.4815 \\
0.1062\end{array}$ & $\begin{array}{l}0.4580 \\
0.8979\end{array}$ \\
\hline-0.0010 & 0.0228 & -0.0010 & 0.0509 & -0.0010 & 0.0564 & -0.0010 & 0.0423 \\
\hline Yes & & Yes & & Yes & & Yes & \\
\hline Yes & & Yes & & Yes & & Yes & \\
\hline $49.19 \%$ & & $48.95 \%$ & & $49.09 \%$ & & $49.05 \%$ & \\
\hline $48.34 \%$ & & $48.10 \%$ & & $48.24 \%$ & & $48.07 \%$ & \\
\hline
\end{tabular}


Table 11A

Firm Value and Expaned Avoidance Measure Governance Models -G-Index

Panel E: Tests of coefficient equality on AVOID variables

Test Value of types of tax avoidance in poorly governed firms

PoorG @ mean

Panel B: $\mathrm{PoOr} \mathrm{G}(\mathrm{Q} 3$

\begin{tabular}{c|c|c}
\hline & Panel C: Poor G @ Top Decile & Panel D: Strong G @ Q2/Poor G @ Q3 \\
Significance & Significance
\end{tabular}

OTHER + OTHER $*$ PoorG $=0$

Significance

Significance
ignificance

0.9292

STOCK + STOCK *PoorG $=0$

$0.6046 \quad 0.9349$

0.4717

$\begin{array}{lll}0.6592 & 0.4717 & 0.9292 \\ 0.8914 & 0.0192 & 0.6373\end{array}$

DEPR + DEPR * PoorG $=0$

0.1689

0.1351

0.8935

0.0117

0.8914

0.1351

0.8935

Test Difference in value among types of avoidance in well governed firms

OTHER $=$ STOCK

0.0898

0.1865

0.1331

0.1848

OTHER $=$ DEPR

0.0009

0.0083

STOCK $=$ DEPR

$0.0437-0.0334$

0.2336

$\begin{array}{lll}0.0002 & 0.0003 & 0.0087 \\ 0.0003 & 0.0017 & 0.1793\end{array}$

$\begin{array}{ll}0.0003 & 0.0011 \\ 0.0257 & 0.0178\end{array}$

$\begin{array}{lll}0.0538 & 0.0257 & 0.0178\end{array}$

0.1793

0.3382
$0.0029-0.1051$

STOCK =RESIDUAL $\quad 0.017$

$\begin{array}{ll}0.004 & 0.0029 \\ 0.0018 & 0.0044\end{array}$

0.1051

Test Difference in value among types of avoidance in poorly governed firms

OTHER +OTHER *PoorG=STOCK +STOCK *PoorG 0.1774

OTHER +OTHER *PoorG=DEPR +DEPR *PoorG

$0.1774 \quad 0.6576$

OTHER +OTHER *PoorG=RESIDUAL +RESIDUAL *PoorG $\quad 0.152$

STOCK + STOCK *PoorG $=$ DEPR + DEPR *PoorG $\quad 0.1374$

STOCK +STOCK *PoorG=RESIDUAL +RESIDUAL *PoorG 0.017

$0.6576 \quad 0.0005$

$0.7932-0.5011$

$0.2133-0.1026$

$\begin{array}{rr}0.6216 & 0.001 \\ 0.004 & 0.0029\end{array}$

DEPR +DEPR *PoorG=RESIDUAL + RESIDUAL *PoorG $\quad 0.0217$

0.004

0.001
0.0029

0.3072

Test Value of types of tax avoidance in strong governance firms

0.2278

0.0491

0.6354

0.7888

0.2116

0.5998

0.0048

0.2259

OTHER + OTHER *StrongG $=0$

STOCK + STOCK *StrongG $=$

DEPR + DEPR *StrongG $=0$

RESIDUAL + RESIDUAL $*$ StrongG $=0$

0.2665

0.1413

0.7117

0.4165

This table presents results of firm value and alternative methods of tax avoidance Model 8 in an agency context. See Appendix A for variable description. Sample Period: 2000-2010. P-values reflect clustering of standard errors at firm level. Governance measured using G-Index (Gompers et al 2003). Variables reported for each of four governance assignments as described in text of paper. Governance Assignment 1 Mean: Poor G = G-Index > Sample Mean 9.896. Governance Assignment 2 Third Quartile: Poor G = G-Index > Sample Third Quartile 12. Governance Assignment 3 Top Decile: Poor G = G-Index > Top

Decile 14. Governance Assignment 4 Extreme Quartiles: Poor G = G-Index > TopQuartile 12/Strong G = G-Index < Low Quartile 8. AVOID STOCK3: Tax avoidance resulting from stock option tax benefits $=$ Option Tax Benefit/Earnings before tax and special items. DEPR AVOID3: Tax avoidance resulting from accelerated tax depreciation deductions $=\triangle \mathrm{DTL}$ PPE/Earnings before tax and special items.

RESIDUAL AVOID3: Tax avoidance resulting from deferral of residual U.S. tax on foreign income $=(\Delta$ PRETAX $+\Delta \mathrm{DTL}$ unremitted foreign earnings $) /$ Earnings before tax and special items. PRETAX -

Estimate based on Bauman and Shaw (2008) estimation method. OTHER AVOID3: Tax avoidance unrelated to specific methods of tax avoidance $=35 \%$-adjusted CETR. Tobin's Q: Ratio of market value of firm to book value of firm $=\left((\right.$ AT $)+\left((\text { PRCC_C })^{*}(\right.$ CSHO $\left.)\right)-($ CEQ $\left.)\right) /($ AT $)$. Options: Average annual value realized from the exercise of options for the top five executives of options by the top five executives grossed up by the fraction of options owned by the covered executives in year t-1 (Execucomp). PPE: Property, plant and equipment, gross = $($ PPEGT/ ATt-1). Foreign Income: Pre-tax income from foreign operations $=(\mathrm{PIFO} / \mathrm{ATt}-1)$. Size: Total Sales (SALE). Risk: Standard deviation of monthly stock returns over previous 36 months (CRSP). Growth: 3 year average sales growth from $\mathrm{t}-2$ to $\mathrm{t}=\sum \mathrm{t}-2, \mathrm{t}(\mathrm{SALEt}$ SALEt-1)/SALEt-1. Leverage: Long-term Debt $=($ DLTT+DLC $) /($ AT $)$. NOL: NOL Carryforward/Total Assets $=($ TLCF/AT $)$. Intangible: Intangible assets $=($ INTAN/ATt-1). Firm Age: Ln $(1+$ number of years listed in Compustat). Cash: Total Cash $=(\mathrm{CHE} / \mathrm{ATt}-1)$. Appreciation: cumulative stock price appreciation over prior four years $=($ Price $\mathrm{t}-1-$ Price $\mathrm{t}-3) /$ Price $\mathrm{t}-3$. Industry controls based on Barth, Cram and Nelson (2001) and Rees and Sivaramakrishnan (2007). 
Table 11B

Firm Value and Expaned Avoidance Measure Governance Models -E-Index

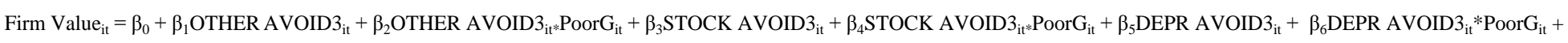

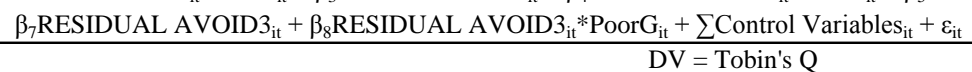

Variables

$\beta_{0}$

OTHER AVOID3

OTHER AVOID3*PoorG

OTHER AVOID3*StrongG

STOCK AVOID3

STOCK AVOID3*PoorG

STOCK AVOID $3 *$ StrongG

DEPR AVOID3

DEPR AVOID3*PoorG

DEPR AVOID3*StrongG

RESIDUAL AVOID3

RESIDUAL AVOID3*PoorG

RESIDUAL AVOID3*StrongG

PoorG

StrongG

Options

PPE

Foreign Income

SIZE

Risk
Growth

Leverage

NOL

Intan

Intang
Firm Age

Cash

Cash*PoorG

Cash*StrongG

Appreciation

Industry Dummies

Year Dummies

$\mathrm{R}$

Adj R

\begin{tabular}{|c|c|c|c|c|c|c|c|}
\hline \multicolumn{2}{|c|}{ Panel A: PoorG @ mean } & \multirow{2}{*}{\multicolumn{2}{|c|}{$\begin{array}{l}\text { Panel B: Poor G @ Q3 } \\
\mathrm{N}=2612\end{array}$}} & \multirow{2}{*}{\multicolumn{2}{|c|}{$\begin{array}{c}\text { Panel C: Poor G @ Top Decile } \\
\mathrm{N}=2612\end{array}$}} & \multicolumn{2}{|c|}{ Panel D: Strong G @ Q2/Poor G @ Q3 } \\
\hline $\mathrm{N}=2612$ & & & & & & $\mathrm{~N}=2612$ & \\
\hline Coeff. & Significance & Coeff. & Significance & Coeff. & Significance & Coeff. & Significance \\
\hline 1.8792 & $<.0001$ & 1.8325 & $<.0001$ & 1.7998 & $<.0001$ & 1.8720 & $<.0001$ \\
\hline 0.4801 & 0.0553 & 0.2664 & 0.1341 & 0.2942 & 0.0555 & 0.1547 & 0.3977 \\
\hline-0.3536 & 0.2167 & 0.0924 & 0.7428 & -0.2902 & 0.4494 & $\begin{array}{l}0.1969 \\
0.2928\end{array}$ & $\begin{array}{l}0.4967 \\
0.4538\end{array}$ \\
\hline 2.1243 & 0.0250 & 2.0730 & 0.0204 & 1.8794 & 0.0163 & 1.2297 & 0.1200 \\
\hline-0.6073 & 0.6605 & -1.0143 & 0.6086 & -6.9702 & 0.0021 & $\begin{array}{c}-0.1025 \\
3.7491\end{array}$ & $\begin{array}{l}0.9579 \\
0.0103\end{array}$ \\
\hline 0.2141 & 0.3489 & 0.1068 & 0.5524 & 0.0988 & 0.5099 & 0.0801 & 0.6677 \\
\hline-0.2426 & 0.3675 & -0.0964 & 0.7215 & -0.4389 & 0.1970 & $\begin{array}{l}-0.0660 \\
-0.0239\end{array}$ & $\begin{array}{l}0.8077 \\
0.9463\end{array}$ \\
\hline-1.3149 & 0.0501 & -0.9207 & 0.0844 & -1.2429 & 0.0129 & -0.8835 & 0.1352 \\
\hline-0.0087 & 0.9921 & -1.4769 & 0.0780 & -1.5621 & 0.1877 & $\begin{array}{c}-1.5257 \\
0.0167\end{array}$ & $\begin{array}{l}0.0820 \\
0.9904\end{array}$ \\
\hline-0.0901 & 0.2670 & -0.0801 & 0.3924 & 0.0999 & 0.2881 & $\begin{array}{l}-0.1130 \\
-0.0523\end{array}$ & $\begin{array}{l}0.2269 \\
0.6089\end{array}$ \\
\hline 0.7664 & $<.0001$ & 0.7862 & $<.0001$ & 0.8146 & $<.0001$ & 0.7610 & $<.0001$ \\
\hline 0.1010 & 0.5123 & 0.0848 & 0.5880 & 0.1009 & 0.5124 & 0.1056 & 0.5021 \\
\hline 9.4773 & $<.0001$ & 9.6493 & $<.0001$ & 9.6230 & $<.0001$ & 9.6140 & $<.0001$ \\
\hline 0.0000 & 0.0895 & 0.0000 & 0.1106 & 0.0000 & 0.1358 & 0.0000 & 0.1091 \\
\hline-2.3177 & $<.0001$ & -2.2638 & $<.0001$ & -2.1938 & $<.0001$ & -2.2945 & $<.0001$ \\
\hline 0.3850 & 0.0114 & 0.3943 & 0.0109 & 0.3758 & 0.0158 & 0.3572 & 0.0189 \\
\hline-0.3472 & 0.1634 & -0.3405 & 0.1725 & -0.3327 & 0.1854 & -0.3343 & 0.1629 \\
\hline-0.1171 & 0.0533 & -0.1194 & 0.0465 & -0.1191 & 0.0558 & -0.1064 & 0.0779 \\
\hline-0.4460 & 0.0005 & -0.4525 & 0.0004 & -0.4510 & 0.0004 & -0.4304 & 0.0005 \\
\hline-0.0539 & 0.1783 & -0.0518 & 0.1971 & -0.0530 & 0.1835 & -0.0523 & 0.1957 \\
\hline 2.1274 & 0.0002 & 2.0827 & $<.0001$ & 2.2158 & $<.0001$ & 1.8889 & $<.0001$ \\
\hline 0.0242 & 0.9722 & 0.3660 & 0.6930 & -0.8768 & 0.1314 & $\begin{array}{l}0.5548 \\
0.0721\end{array}$ & $\begin{array}{l}0.5479 \\
0.9330\end{array}$ \\
\hline-0.0011 & 0.0374 & -0.0010 & 0.0519 & -0.0010 & 0.0517 & -0.0010 & 0.0810 \\
\hline Yes & & Yes & & Yes & & Yes & \\
\hline Yes & & Yes & & Yes & & Yes & \\
\hline $49.12 \%$ & & $49.14 \%$ & & $49.12 \%$ & & $49.82 \%$ & \\
\hline $48.27 \%$ & & $48.29 \%$ & & $48.26 \%$ & & $48.86 \%$ & \\
\hline
\end{tabular}


Table 11B

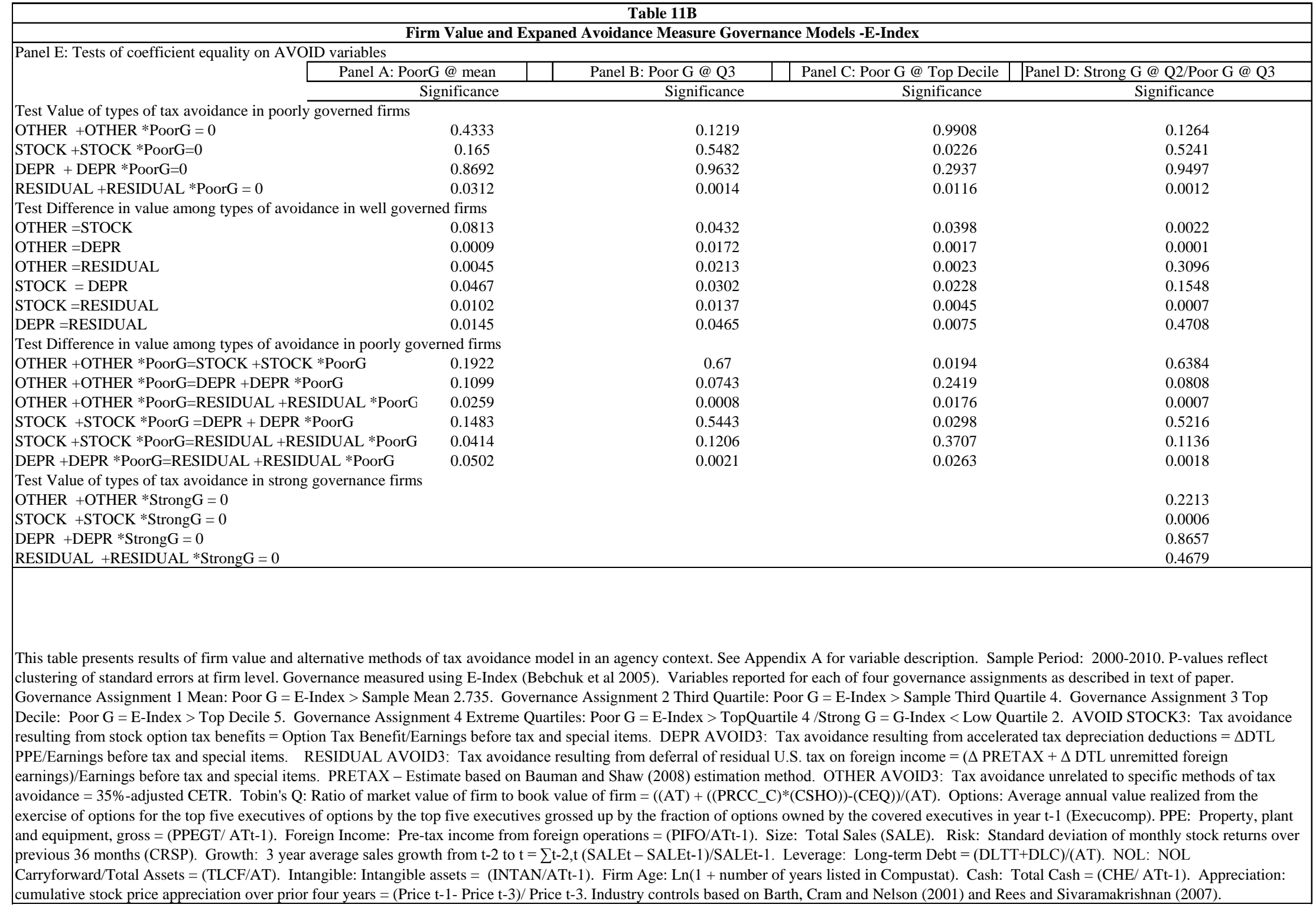


Table 12

Firm Value and Expaned Avoidance Measure Governance Models -G-Index and Tax Havens

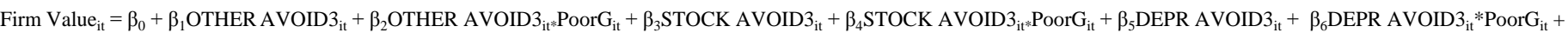
$\beta_{7}$ RESIDUAL AVOID $_{\mathrm{it}}+\beta_{8}$ RESIDUAL AVOID $_{\mathrm{it}}{ }^{*}$ Haven $_{\mathrm{it}}+\beta_{9}$ RESIDUAL AVOID $_{\mathrm{it}} *$ PoorG $_{\mathrm{it}} * \mathrm{Haven}_{\mathrm{it}}+\sum$ Control Variables $_{\mathrm{it}}+\varepsilon_{\mathrm{il}}$

\begin{tabular}{|c|c|c|c|c|c|c|c|c|}
\hline \multirow{5}{*}{$\begin{array}{l} \\
\text { Variables } \\
\beta_{0}\end{array}$} & \multicolumn{8}{|c|}{$\mathrm{DV}=$ Tobin's Q } \\
\hline & \multirow{2}{*}{\multicolumn{2}{|c|}{$\begin{array}{l}\text { Panel A: PoorG @ mean } \\
\mathrm{N}=2522\end{array}$}} & \multirow{2}{*}{\multicolumn{2}{|c|}{$\begin{array}{l}\text { Panel B: Poor G @ Q3 } \\
\mathrm{N}=2522\end{array}$}} & \multirow{2}{*}{\multicolumn{2}{|c|}{ Panel C: Poor G @ Top Decile }} & \multicolumn{2}{|c|}{ Panel D: Strong G @ Q2/Poor G @ Q3 } \\
\hline & & & & & & & $\mathrm{N}=2522$ & \\
\hline & Coeff. & Significance & Coeff. & Significance & Coeff. & Significance & Coeff. & Significance \\
\hline & 1.941 & $<.0001$ & 1.831 & $<.0001$ & 1.836 & $<.0001$ & 1.78 & $<.0001$ \\
\hline OTHER AVOID3 & 0.424 & 0.1091 & 0.36 & 0.046 & 0.269 & 0.0834 & 0.309 & 0.0658 \\
\hline OTHER AVOID3*PoorG & -0.261 & 0.3875 & -0.34 & 0.236 & 0.079 & 0.8428 & -0.281 & 0.3114 \\
\hline OTHER AVOID3*StrongG & & & & & & & 0.132 & 0.726 \\
\hline STOCK AVOID3 & 2.367 & 0.0394 & 2.294 & 0.0154 & 1.972 & 0.017 & 2.621 & 0.0269 \\
\hline STOCK AVOID3*PoorG & -1.181 & 0.3995 & -2.293 & 0.0593 & -3.05 & 0.0024 & -2.575 & 0.0636 \\
\hline STOCK AVOID3*StrongG & & & & & & & -0.456 & 0.8028 \\
\hline DEPR AVOID3 & 0.102 & 0.6709 & 0.102 & 0.5548 & 0.026 & 0.8642 & 0.121 & 0.515 \\
\hline DEPR AVOID3*PoorG & -0.041 & 0.885 & -0.065 & 0.8373 & 0.47 & 0.2013 & -0.081 & 0.8055 \\
\hline DEPR AVOID3*StrongG & & & & & & & 0.009 & 0.9782 \\
\hline RESIDUAL AVOID3 & -1.99 & 0.3674 & -1.496 & 0.0591 & -1.163 & 0.2194 & -1.543 & 0.0484 \\
\hline RESIDUAL AVOID3*Haven & 0.146 & 0.9256 & 0.329 & 0.7273 & -0.279 & 0.7888 & -0.823 & 0.3493 \\
\hline RESIDUAL AVOID3*PoorG & 0.177 & 0.9151 & 0.995 & 0.5308 & 0.953 & 0.6622 & 1.036 & 0.5049 \\
\hline RESIDUAL AVOID3*PoorG*Haven & -0.9 & 0.6349 & -1.879 & 0.324 & -1.006 & 0.7111 & -0.739 & 0.6937 \\
\hline RESIDUAL AVOID3*StrongG & & & & & & & 0.099 & 0.9622 \\
\hline RESIDUAL AVOID $3 *$ StrongG*Haven & & & & & & & 2.231 & 0.3512 \\
\hline Haven & -0.159 & 0.0538 & -0.075 & 0.2375 & -0.042 & 0.4373 & -0.027 & 0.7194 \\
\hline PoorG & -0.214 & 0.0388 & -0.06 & 0.502 & -0.069 & 0.4753 & -0.023 & 0.7955 \\
\hline PoorG*Haven & 0.233 & 0.0126 & 0.155 & 0.0959 & 0.132 & 0.2115 & 0.107 & 0.2834 \\
\hline StrongG & & & & & & & 0.1 & 0.4402 \\
\hline StrongG*Haven & & & & & & & -0.116 & 0.3318 \\
\hline Options & 0.742 & $<.0001$ & 0.752 & $<.0001$ & 0.758 & $<.0001$ & 0.741 & $<.0001$ \\
\hline PPE & 0.092 & 0.5441 & 0.095 & 0.5503 & 0.096 & 0.5522 & 0.103 & 0.5082 \\
\hline Foreign Income & 9.654 & $<.0001$ & 9.673 & $<.0001$ & 9.572 & $<.0001$ & 9.71 & $<.0001$ \\
\hline SIZE & -.000 & 0.0738 & -.000 & 0.1389 & -.000 & 0.1356 & -.000 & 0.0971 \\
\hline Risk & -2.406 & $<.0001$ & -2.265 & $<.0001$ & -2.352 & $<.0001$ & -2.272 & $<.0001$ \\
\hline Growth & 0.417 & 0.0069 & 0.432 & 0.0081 & 0.445 & 0.0066 & 0.426 & 0.0092 \\
\hline Leverage & -0.376 & 0.138 & -0.346 & 0.1899 & -0.353 & 0.1795 & -0.362 & 0.1595 \\
\hline $\mathrm{NOL}$ & -0.116 & 0.0636 & -0.124 & 0.0531 & -0.127 & 0.0473 & -0.119 & 0.0592 \\
\hline Intang & -0.434 & 0.0024 & -0.439 & 0.0028 & -0.433 & 0.0027 & -0.439 & 0.0018 \\
\hline Firm Age & -0.041 & 0.3274 & -0.041 & 0.3444 & -0.047 & 0.2604 & -0.038 & 0.3786 \\
\hline Cash & 2.176 & 0.001 & 2.197 & $<.0001$ & 2.212 & $<.0001$ & 2.214 & $<.0001$ \\
\hline Cash*PoorG & 0.011 & 0.9891 & -0.211 & 0.7618 & -1.144 & 0.1573 & -0.223 & 0.7496 \\
\hline Cash*StrongG & & & & & & & -0.048 & 0.96 \\
\hline Appreciation & -0.002 & $<.0001$ & -0.002 & $<.0001$ & -0.002 & $<.0001$ & -0.002 & $<.0001$ \\
\hline Industry Dummies & Yes & & Yes & & Yes & & Yes & \\
\hline Year Dummies & Yes & & Yes & & Yes & & Yes & \\
\hline $\mathrm{R}$ & $49.52 \%$ & & $49.21 \%$ & & $49.13 \%$ & & $49.39 \%$ & \\
\hline $\operatorname{Adj} R$ & $48.56 \%$ & & $48.24 \%$ & & $48.16 \%$ & & $48.26 \%$ & \\
\hline
\end{tabular}


Table 12

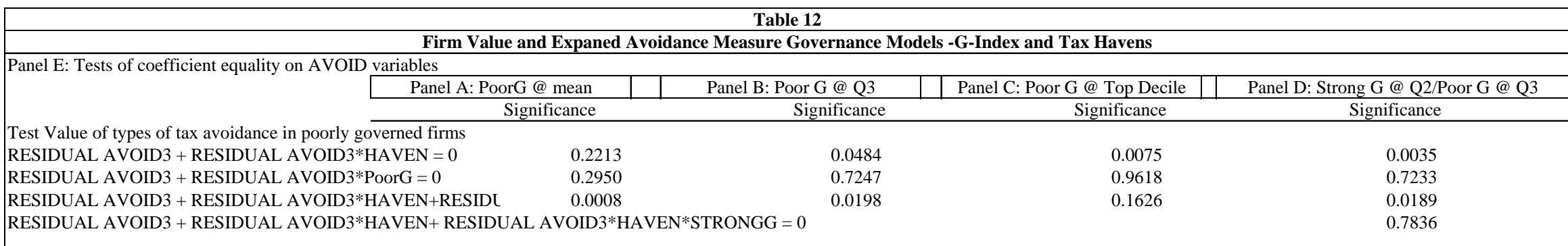

This table presents results of firm value and alternative methods of tax avoidance model in an agency context. See Appendix A for variable description. Sample Period: 2000-2010. P-values reflect clustering of standard errors at firm level. Governance measured using G-Index (Gompers et al 2003). Variables reported for each of four governance assignments as described in text of paper. Governance Assignment 1 Mean: Poor G = G-Index > Sample Mean 9.896. Governance Assignment 2 Third Quartile: Poor G = G-Index > Sample Third Quartile 12. Governance Assignment 3 Top Decile: Poor G = G-Index > Top Decile 14. Governance Assignment 4 Extreme Quartiles: Poor G = G-Index > TopQuartile 12 /Strong G = G-Index < Low Quartile 8. AVOID STOCK3: Tax avoidance resulting from stock option tax benefits $=$ Option Tax Benefit/Earnings before tax and special items. DEPR AVOID3: Tax avoidance resulting from accelerated tax depreciation deductions $=\Delta \mathrm{DTL}$ PPE/Earnings before tax and special items.

RESIDUAL AVOID3: Tax avoidance resulting from deferral of residual U.S. tax on foreign income $=(\triangle$ PRETAX $+\Delta$ DTL unremitted foreign earnings $) /$ Earnings before tax and special items. PRETAX -

Estimate based on Bauman and Shaw (2008) estimation method. OTHER AVOID3: Tax avoidance unrelated to specific methods of tax avoidance $=35 \%$-adjusted CETR. Tobin's Q: Ratio of market value of firm to book value of firm $=\left((\mathrm{AT})+\left(\left(\mathrm{PRCC} \_\mathrm{C}\right) *(\mathrm{CSHO})\right)-(\mathrm{CEQ})\right) /(\mathrm{AT})$. Options: Average annual value realized from the exercise of options for the top five executives of options by the top five executives grossed up by the fraction of options owned by the covered executives in year t-1 (Execucomp). PPE: Property, plant and equipment, gross = (PPEGT/ ATt-1). Foreign Income: Pre-tax income from foreign

operations $=(\mathrm{PIFO} / \mathrm{ATt}-1)$. Size: Total Sales $(\mathrm{SALE})$. Risk: Standard deviation of monthly stock returns over previous 36 months $(\mathrm{CRSP})$. Growth: 3 year average sales growth from $\mathrm{t}-2$ to $\mathrm{t}=\sum \mathrm{t}-2, \mathrm{t}(\mathrm{SALEt}$ - SALEt-1)/SALEt-1. Leverage: Long-term Debt $=($ DLTT+DLC $) /(A T)$. NOL: NOL Carryforward/Total Assets $=($ TLCF $/$ AT $)$. Intangible: Intangible assets $=($ INTAN/ATt-1 $)$. Firm Age: Ln $(1+$ number of years listed in Compustat). Cash: Total Cash $=(\mathrm{CHE} / \mathrm{ATt}-1)$. Appreciation: cumulative stock price appreciation over prior four years $=($ Price $\mathrm{t}-1-$ Price $\mathrm{t}-3) /$ Price $\mathrm{t}-3$. Industry controls based on Barth, Cram and Nelson (2001) and Rees and Sivaramakrishnan (2007). 
Table 13A

Firm Value and Alternative Avoidance Measure Governance Models - G-Index

Expansion of Residual Tax Deferral

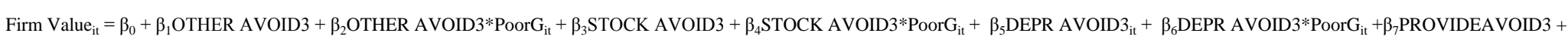

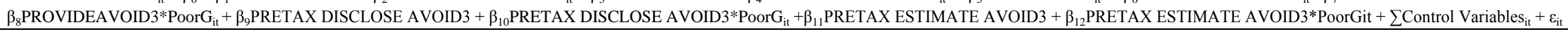

Variables

$\beta_{0}$

OTHER AVOID3

OTHER AVOID3*PoorG

OTHER AVOID $3 *$ StrongG

STOCK AVOID3

STOCK AVOID3*PoorG

STOCK AVOID $3 *$ StrongG

DEPR AVOID3

DEPR AVOID3*PoorG

DEPR AVOID $3 *$ StrongG

PROVIDE AVOID3

PROVIDE AVOID3*PoorG

ROVIDE AVOID $3 *$ StrongG

PRETAX DISCLOSE AVOID3
PRETAX DISCLOSE AVOID3*PoorG

PRETAX DISCLOSE AVOID3*PoorG
PRETAX DISCLOSE AVOID3*StrongG

PRETAX ESTIMATE AVOID3

PRETAX ESTIMATE AVOID3*PoorG

PRETAX ESTIMATE AVOID3*StrongG

PoorG
PRETAX

StrongG

Options

PPE

Foreign Income

Size

Risk
Growth

Leverage

NOL

Intang

Firm Age

Cash

Panel A: PoorG @ mean

DV = Tobin's $Q$

\begin{tabular}{|c|c|c|c|c|c|c|c|}
\hline \multicolumn{2}{|c|}{ Panel A: PoorG @ mean } & \multicolumn{2}{|c|}{ Panel B: Poor G @ Q3 } & \multicolumn{2}{|c|}{ Panel C: Poor G @ Top Decile } & \multicolumn{2}{|c|}{ Panel D: Strong G @ Q2/Poor G @ Q3 } \\
\hline \multicolumn{2}{|c|}{$\mathrm{N}=2612$} & \multicolumn{2}{|c|}{$\mathrm{N}=2612$} & \multicolumn{2}{|c|}{$\mathrm{N}=2612$} & \multicolumn{2}{|c|}{$\mathrm{N}=2612$} \\
\hline Coeff. & Significance & Coeff. & Significance & Coeff. & Significance & Coeff. & Significance \\
\hline 1.8340 & $<.0001$ & 1.7944 & $<.0001$ & 1.8055 & $<.0001$ & 1.8048 & $<.0001$ \\
\hline 0.5063 & 0.0295 & 0.3998 & 0.0147 & 0.3447 & 0.0225 & 0.3570 & 0.0249 \\
\hline \multirow[t]{2}{*}{-0.3305} & 0.2368 & -0.2979 & 0.3646 & -0.0830 & 0.8172 & -0.2491 & 0.4420 \\
\hline & & & & & & 0.0644 & 0.8498 \\
\hline 2.1031 & 0.0369 & 2.2609 & 0.0187 & 2.0414 & 0.0156 & 2.3147 & 0.0451 \\
\hline \multirow[t]{2}{*}{-0.6526} & 0.6421 & -1.9120 & 0.1224 & -3.2621 & 0.0010 & -1.9209 & 0.1497 \\
\hline & & & & & & -0.0137 & 0.9939 \\
\hline 0.2217 & 0.3178 & 0.1714 & 0.3004 & 0.1131 & 0.4545 & 0.1661 & 0.3606 \\
\hline \multirow[t]{2}{*}{-0.1794} & 0.5139 & -0.1304 & 0.6949 & 0.2941 & 0.2975 & -0.1258 & 0.7134 \\
\hline & & & & & & -0.0164 & 0.9610 \\
\hline-1.4774 & 0.2811 & -1.5495 & 0.1561 & -1.7097 & 0.0817 & -1.5991 & 0.4092 \\
\hline \multirow[t]{2}{*}{-0.6320} & 0.7211 & -2.0860 & 0.4224 & 0.8109 & 0.6157 & -2.0410 & 0.5259 \\
\hline & & & & & & -0.1948 & 0.9386 \\
\hline-0.8033 & 0.6977 & -1.6171 & 0.1089 & -1.7361 & 0.0456 & -2.1089 & 0.0355 \\
\hline \multirow[t]{2}{*}{-1.2645} & 0.5743 & -0.3098 & 0.8758 & 51.5399 & 0.2228 & 0.1952 & 0.9196 \\
\hline & & & & & & 4.1778 & 0.3050 \\
\hline-0.4418 & 0.3580 & -0.2661 & 0.4030 & -0.3060 & 0.3196 & -0.0488 & 0.8835 \\
\hline \multirow[t]{2}{*}{0.1643} & 0.7817 & -0.2717 & 0.7044 & -0.5141 & 0.5616 & -0.4939 & 0.4921 \\
\hline & & & & & & -0.4805 & 0.4443 \\
\hline \multirow[t]{2}{*}{-0.0794} & 0.3753 & -0.0292 & 0.7206 & 0.0053 & 0.9422 & -0.0260 & 0.7512 \\
\hline & & & & & & 0.0271 & 0.7980 \\
\hline 0.7850 & $<.0001$ & 0.7861 & $<.0001$ & 0.7800 & $<.0001$ & 0.7793 & $<.0001$ \\
\hline 0.0965 & 0.5210 & 0.0841 & 0.5895 & 0.0815 & 0.6048 & 0.0926 & 0.5448 \\
\hline 9.2687 & $<.0001$ & 9.3703 & $<.0001$ & 9.3309 & $<.0001$ & 9.3979 & $<.0001$ \\
\hline 0.0000 & 0.1084 & 0.0000 & 0.1619 & 0.0000 & 0.1578 & 0.0000 & 0.1377 \\
\hline-2.2764 & $<.0001$ & -2.1727 & $<.0001$ & -2.2025 & $<.0001$ & -2.2159 & $<.0001$ \\
\hline 0.3529 & 0.0197 & 0.3818 & 0.0139 & 0.3785 & 0.0144 & 0.3747 & 0.0185 \\
\hline-0.3646 & 0.1428 & -0.3220 & 0.2096 & -0.3378 & 0.1852 & -0.3317 & 0.1886 \\
\hline-0.1161 & 0.0588 & -0.1227 & 0.0501 & -0.1219 & 0.0541 & -0.1212 & 0.0500 \\
\hline-0.4325 & 0.0008 & -0.4490 & 0.0007 & -0.4442 & 0.0006 & -0.4439 & 0.0005 \\
\hline-0.0483 & 0.2296 & -0.0506 & 0.2211 & -0.0532 & 0.1882 & -0.0534 & 0.1965 \\
\hline 2.1865 & 0.0002 & 2.0731 & $<.0001$ & 2.2008 & $<.0001$ & 2.0249 & $<.0001$ \\
\hline \multirow[t]{2}{*}{-0.1170} & 0.8650 & 0.3838 & 0.5813 & -1.0980 & 0.1313 & 0.4390 & 0.5086 \\
\hline & & & & & & 0.0224 & 0.9785 \\
\hline-0.0010 & 0.0211 & -0.0010 & 0.0457 & -0.0010 & 0.0500 & -0.0010 & 0.0424 \\
\hline Yes & & Yes & & Yes & & Yes & \\
\hline Yes & & Yes & & Yes & & Yes & \\
\hline $49.10 \%$ & & $48.89 \%$ & & $48.99 \%$ & & $49.05 \%$ & \\
\hline $48.17 \%$ & & $47.96 \%$ & & $48.05 \%$ & & $47.95 \%$ & \\
\hline
\end{tabular}


Table 13A

Firm Value and Alternative Avoidance Measure Governance Models - G-Index

Expansion of Residual Tax Deferral

Panel E: Tests of coefficient equality on AVOID variables

Test Value of types of tax avoidance in poorly governed firms

PROVIDE +PROVIDE $*$ PoorG $=0$

PRETAX DISCLOSE +PRETAX DISCLOSE *PoorG $=0$

PRETAX ESTIMATE + PRETAX ESTIMATE $*$ PoorG $=0$

Test Difference in value among types of avoidance in well governed firms

PROVIDE $=$ PRETAX DISCLOSE

PROVIDE $=$ PRETAX ESTIMATE

PRETAX DISCLOSE $=$ PRETAX ESTIMATE

Test Difference in value among types of avoidance in poorly governed firm

促

RRET AX DISCLOSE + POETAX DISCLOSE $P O M T$ - PRET AX ESTIMATE + PR

\begin{tabular}{|c|c|c|c|c|}
\hline Panel A: Poc & rG@ mean & Panel B: Poor G @ Q3 & Panel C: Poor G @ Top Decile & Panel D: Strong G @ Q2/Poor G @ Q3 \\
\hline & Significance & Significanc & $\begin{array}{r}\text { Significance } \\
\end{array}$ & $\begin{array}{c}\text { Significance } \\
\end{array}$ \\
\hline & 0.0705 & 0.1062 & 0.4867 & 0.1 \\
\hline & 0.0107 & 0.2667 & 0.2387 & 0.02694 \\
\hline & 0.4468 & 0.4108 & 0.3292 & 0.408 \\
\hline & 0.801 & 0.9654 & 0.9841 & 0.3582 \\
\hline & 0.4541 & 0.2456 & 0.1643 & 0.3797 \\
\hline & 0.8645 & 0.1766 & 0.0916 & 0.5193 \\
\hline OSE *PoorG & 0.9766 & 0.4988 & 0.2299 & 0.4956 \\
\hline IATE *PoorG & 0.1354 & 0.2111 & 0.9623 & 0.2133 \\
\hline TE +PRETAX E & 0.017 & 0.3785 & 0.2238 & 0.3834 \\
\hline & & & & 0.1877 \\
\hline & & & & 0.5898 \\
\hline & & & & 0.3397 \\
\hline
\end{tabular}

ROVIDE +PROVIDE "StrongG $=0$

RRETAX ESTIMATE + PRETAX ESTIMATE $*$ StrongG $=0$
PRE

This table presents results of firm value and alternative methods of tax avoidance model in an agency context including the expansion of RESIDUAL AVOID3 into the three methods of disclosing residual tax deferral. See Appendix A for variable description. Sample Period: 2000-2010. P-values reflect clustering of standard errors at firm level. Governance measured using G-Index (Gompers et al 2003). Variables reported for each of four governance assignments as described in text of paper. Governance Assignment 1 Mean: Poor G = G-Index > Sample Mean 9.896. Governance Assignment 2 Third Quartile: Poor G = G-Index > Sample Third Quartile 12. Governance Assignment 3 Top Decile: Poor G = G-Index > Top Decile 14. Governance Assignment 4 Extreme Quartiles: Poor G = G-Index > TopQuartile 12 /Strong G = G-Index < Low Quartile 8. STOCK AVOID3: Tax

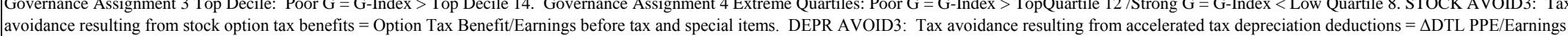
avoidance resulting from stock option tax benefits $=$ Option Tax Benefit/Earnings before tax and special items. DEPR AVOID3: Tax avoidance resulting from accelerated tax depreciation deductions = $\triangle \mathrm{DTL}$ PPE/Earnings
before tax and special items. PROVIDE AVOID3: Tax avoidance related to provision of deferred tax expense on unrepatriated foreign earnings. PRETAX DISCLOSE AVOID3: Tax avoidance related to disclosed unrecognized before tax and special items. PROVIDE AVOID3: Tax avoidance related to provision of deferred tax expense on unrepatriated foreign earnings. PRETAX DISCLOSE AVOID3: Tax avoidance related to disclosed unrecognized
tax liability on unrepatriated foreign earnings. PRETAX ESTIMATE AVOID3: Tax avoidance related to estimated unrecognized tax liability on unrepatriated foreign earnings. PRETAX - Estimate based on Bauman and Shaw tax liability on unrepatriated foreign earnings. PRETAX ESTIMATE AVOID3: Tax avoidance related to estimated unrecognized tax liability on unrepatriated foreign earnings. PRETAX - Estimate based on Ba
(2008) estimation method. OTHER AVOID3: Tax avoidance unrelated to specific methods of tax avoidance $=35 \%$-adjusted CETR. Tobin's Q: Ratio of market value of firm to book value of firm $=(($ AT $)+$

$(2008)$ estimation method. OTHER AVOID3: Tax avoidance unrelated to specific methods of tax avoidance $=35 \%$-adjusted CETR. Tobin's Q: Ratio of market value of firm to book value of firm $=(($ AT $)+$
$($ (PRCC_C $) *(C S H O))-(C E Q)) /($ AT $)$. Options: Average annual value realized from the exercise of options for the top five executives of options by the top five executives grossed up by the fraction of options owned by the $\left.\left(\left(\mathrm{PRCC} \_\mathrm{C}\right) *(\mathrm{CSHO})\right)-(\mathrm{CEQ})\right) /(\mathrm{AT})$. Options: Average annual value realized from the exercise of options for the top five executives of options by the top five executives grossed up by the fraction of options owned by the
covered executives in year t-1 (Execucomp). PPE: Property, plant and equipment, gross = (PPEGT/ ATt-1). Foreign Income: Pre-tax income from foreign operations = (PIFO/ATt-1). Size: Total Sales (SALE). Risk: Standard deviation of monthly stock returns over previous 36 month (CRSP). Growth: 3 year average sales growth from $t-2$ to $t=\sum t-2, t($ SALEt - SALEt-1)/SALEt-1. Leverage: Long-term Debt $=($ DLTT + DLC) $/($ AT). NOL: NOL Carryforward/Total Assets $=($ TLCF/AT $)$. Intangible: Intangible assets $=($ INTAN/ATt-1 $)$. Firm Age: $\operatorname{Ln}(1+$ number of years listed in Compustat $)$. Cash: Total Cash $=($ CHE/ ATt- 1$)$. Appreciation: cumulative stock price appreciation over prior four years = (Price t-1- Price t-3)/ Price t-3. Industry controls based on Barth, Cram and Nelson (2001) and Rees and Sivaramakrishnan (2007). 
Table 13B

Firm Value and Alternative Avoidance Measure Governance Models - E-Index

Expansion of Residual Tax Deferral

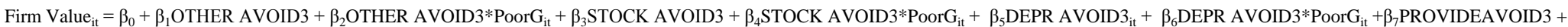
$\beta_{8}$ PROVIDEAVOID3* PoorG $_{\text {it }}+$

$\beta_{9}$ PRETAX DISCLOSE AVOID $3+\beta_{10}$ PRETAX DISCLOSE AVOID3 $*$ PoorG $_{i 1}+\beta_{11}$ PRETAX ESTIMATE AVOID $3+\beta_{12}$ PRETAX ESTIMATE

Variables

OTHER AVOID3

OTHER AVOID $3 *$ PoorG

OTHER AVOID $3 *$ StrongC

STOCK AVOID3

STOCK AVOID3*PoorG

STOCK AVOID $3 *$ StrongG

DEPR AVOID3

DEPR AVOID3*PoorG

DEPR AVOID3*StrongG

PROVIDE AVOID 3

PROVIDE AVOID3*PoorG

PROVIDE AVOID3*StrongG

PRETAX DISCLOSE AVOID3

PRETAX DISCLOSE AVOID3*PoorG

PRETAX DISCLOSE AVOID3*StrongG

PRETAX ESTIMATE AVOID3

PRETAX ESTIMATE AVOID3*PoorG

PRETAX ESTIMATE AVOID3*StrongG

PoorG

StrongG

Strong
Option
PPE

Foreign Income

Size

Risk
Growth

Leverage

NOL

Intang

Cash

Cash*PoorG

Cash*StrongG

Appreciation

Industry Dummies

Year Dummies

R Adj
AVOID3*Poor $_{\text {it }}+\sum$ Control Variables $_{\text {it }}+\varepsilon_{\text {it }}$

\begin{tabular}{|c|c|c|c|c|c|c|c|}
\hline \multicolumn{2}{|c|}{ Panel A: PoorG @ mean } & \multicolumn{2}{|c|}{ Panel B: Poor G @ Q3 } & \multicolumn{2}{|c|}{ Panel C: Poor G @ Top Decile } & \multicolumn{2}{|c|}{ Panel D: Strong G @ Q2/Poor G @ Q3 } \\
\hline $\mathrm{N}=2612$ & & $\mathrm{~N}=2612$ & & $\mathrm{~N}=2612$ & & $\mathrm{~N}=2612$ & \\
\hline Coeff. & Significance & Coeff. & Significance & Coeff. & Significance & Coeff. & Significance \\
\hline 1.8902 & $<.0001$ & 1.8584 & $<.0001$ & 1.8202 & $<.0001$ & 1.8995 & $<.0001$ \\
\hline 0.6082 & 0.0099 & 0.3423 & 0.0519 & 0.3811 & 0.0128 & 0.2282 & 0.2150 \\
\hline \multirow[t]{2}{*}{-0.4119} & 0.1338 & 0.0986 & 0.7183 & -0.4193 & 0.1635 & 0.2062 & 0.4656 \\
\hline & 00194 & 21397 & 00204 & 19208 & & $\begin{array}{l}0.2886 \\
12485\end{array}$ & $\begin{array}{l}0.4637 \\
0.1328\end{array}$ \\
\hline 2.3302 & 0.0194 & 2.1397 & 0.0204 & 1.9208 & 0.0167 & 1.2485 & 0.1328 \\
\hline-0.9583 & 0.4985 & -1.1082 & 0.5913 & -7.4866 & 0.0014 & $\begin{array}{c}-0.1335 \\
3.8827\end{array}$ & $\begin{array}{l}0.9478 \\
0.0085\end{array}$ \\
\hline 0.3256 & 0.1287 & 0.1685 & 0.3398 & 0.1705 & 0.2510 & 0.1352 & 0.4719 \\
\hline \multirow[t]{2}{*}{-0.2916} & 0.2659 & -0.0194 & 0.9446 & -0.4273 & 0.1936 & 0.0198 & 0.9444 \\
\hline & & & & & & -0.0263 & 0.9424 \\
\hline-2.2381 & 0.1767 & -1.3082 & 0.2160 & -1.5509 & 0.1100 & -0.7923 & 0.4594 \\
\hline \multirow[t]{2}{*}{-1.2521} & 0.5817 & -3.7092 & 0.1020 & -6.2504 & 0.0467 & -4.2380 & 0.0628 \\
\hline & & & & & & -0.8812 & 0.7576 \\
\hline-1.2039 & 0.3648 & -0.8485 & 0.5504 & -1.4054 & 0.1509 & -0.9847 & 0.5112 \\
\hline \multirow[t]{2}{*}{-0.5443} & 0.7277 & -1.2026 & 0.5008 & -2.2938 & 0.2266 & -1.1361 & 0.5331 \\
\hline & & & & & & -1.1152 & 0.8672 \\
\hline-0.5007 & 0.2746 & -0.4351 & 0.2327 & -0.3321 & 0.3012 & -0.2651 & 0.4780 \\
\hline \multirow[t]{2}{*}{0.2424} & 0.6509 & 0.1977 & 0.6418 & 0.0576 & 0.9274 & 0.0316 & 0.9427 \\
\hline & & & & & & -0.7795 & 0.2680 \\
\hline \multirow[t]{2}{*}{-0.0801} & 0.3176 & -0.0937 & 0.3352 & 0.0914 & 0.3108 & -0.1297 & 0.1864 \\
\hline & & & & & & -0.0619 & 0.5571 \\
\hline 0.7688 & $<.0001$ & 0.7910 & $<.0001$ & 0.8189 & $<.0001$ & 0.7615 & $<.0001$ \\
\hline 0.1122 & 0.4694 & 0.0839 & 0.5926 & 0.1089 & 0.4833 & 0.1042 & 0.5097 \\
\hline 9.1940 & $<.0001$ & 9.3198 & $<.0001$ & 9.3678 & $<.0001$ & 9.2767 & $<.0001$ \\
\hline 0.0000 & 0.1153 & 0.0000 & 0.1396 & 0.0000 & 0.1601 & 0.0000 & 0.1555 \\
\hline-2.3162 & $<.0001$ & -2.2601 & $<.0001$ & -2.1771 & $<.0001$ & -2.2645 & $<.0001$ \\
\hline 0.3763 & 0.0126 & 0.3836 & 0.0126 & 0.3684 & 0.0175 & 0.3506 & 0.0203 \\
\hline-0.3639 & 0.1498 & -0.3506 & 0.1665 & -0.3413 & 0.1781 & -0.3399 & 0.1625 \\
\hline-0.1184 & 0.0499 & -0.1266 & 0.0351 & -0.1236 & 0.0494 & -0.1190 & 0.0481 \\
\hline-0.4406 & 0.0006 & -0.4426 & 0.0005 & -0.4461 & 0.0005 & -0.4232 & 0.0007 \\
\hline-0.0561 & 0.1658 & -0.0556 & 0.1709 & -0.0574 & 0.1557 & -0.0572 & 0.1606 \\
\hline 2.0912 & 0.0002 & 2.0744 & $<.0001$ & 2.2068 & $<.0001$ & 1.9029 & $<.0001$ \\
\hline \multirow[t]{2}{*}{0.0730} & 0.9166 & 0.3469 & 0.7100 & -0.8987 & 0.1512 & 0.5167 & 0.5801 \\
\hline & & & & & & 0.0279 & 0.9735 \\
\hline-0.0011 & 0.0326 & -0.0010 & 0.0464 & -0.0010 & 0.0458 & -0.0010 & 0.0753 \\
\hline Yes & & Yes & & Yes & & Yes & \\
\hline Yes & & Yes & & Yes & & Yes & \\
\hline $49.07 \%$ & & $49.06 \%$ & & $49.04 \%$ & & $49.80 \%$ & \\
\hline $48.13 \%$ & & $48.12 \%$ & & $48.11 \%$ & & $48.72 \%$ & \\
\hline
\end{tabular}


Table 13B

Firm Value and Alternative Avoidance Measure Governance Models - E-Index

Expansion of Residual Tax Deferral

Panel E: Tests of coefficient equality on AVOID variables

Test Value of types of tax avoidance in poorly governed firms

PROVIDE +PROVIDE *PoorG $=0$

PRETAX DISCLOSE +PRETAX DISCLOSE $*$ PoorG $=0$

PRETAX ESTIMATE + PRETAX ESTIMATE *PoorG $=0$

Test Difference in value among types of avoidance in well governed firm

PROVIDE $=$ PRETAX DISCLOSE

PROVIDE $=$ PRETAX ESTIMATE

PRETAX DISCLOSE $=$ PRETAX ESTIMATE

Test Difference in value among types of avoidance in poorly governed firms

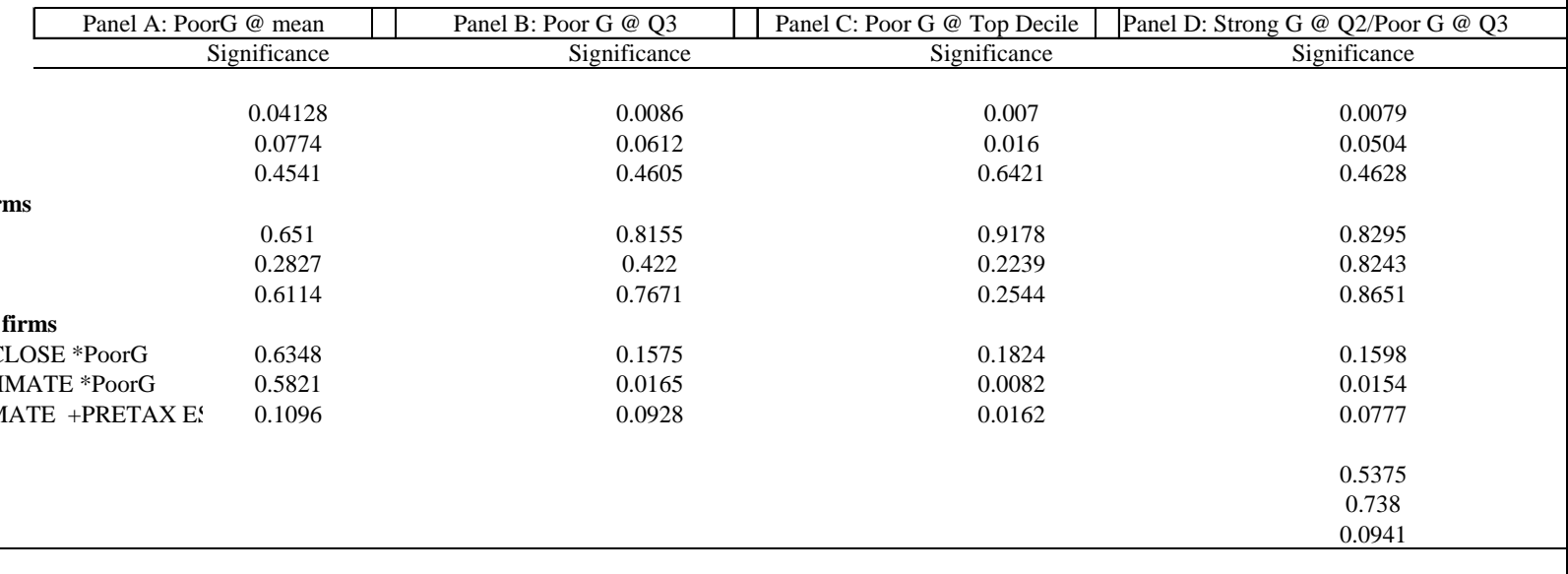

PROVIDE +PROVIDE *PoorG $=$ PRETAX DISCLOSE +PRETAX DISCLOSE *PoorG

PROVIDE +PROVIDE $*$ PoorG $=$ PRETAX ESTIMATE + PRETAX ESTIMATE $*$ PoorG

PRETAX DISCLOSE +PRETAX DISCLOSE *PoorG $=$ PRETAX ESTIMATE +PRETAX

Test Value of types of tax avoidance in strong governance firms

PROVIDE + PROVIDE $*$ StrongG $=0$

PRETAX DISCLOSE +PRETAX DISCLOSE $*$ StrongG $=0$

PRETAX ESTIMATE + PRETAX ESTIMATE $*$ StrongG $=0$

This table presents results of firm value and alternative methods of tax avoidance model in an agency context including the expansion of RESIDUAL AVOID3 into the three methods of disclosing residual tax deferral. See Appendix $\mathrm{A}$ for variable description. Sample Period: 2000-2010. P-values reflect clustering of standard errors at firm level. Governance measured using E-Index (Bebchuk et al 2005). Variables reported for each of four governance assignments as described in text of paper. Governance Assignment 1 Mean: Poor G = E-Index > Sample Mean 2.735. Governance Assignment 2 Third Quartile: Poor G = E-Index > Sample Third Quartile 4. Governance Assignment 3 Top

Decile: Poor G = E-Index > Top Decile 5. Governance Assignment 4 Extreme Quartiles: Poor G = E-Index > TopQuartile 4/Strong G = G-Index < Low Quartile 2. STOCK AVOID3: Tax avoidance resulting from stock option tax benefits $=$ Option Tax Benefit/Earnings before tax and special items. DEPR AVOID3: Tax avoidance resulting from accelerated tax depreciation deductions $=\triangle D T L$ PPE/Earnings before tax and special items. PROVIDE AVOID3: Tax avoidance related to provision of deferred tax expense on unrepatriated foreign earnings. PRETAX DISCLOSE AVOID3: Tax avoidance related to disclosed unrecognized tax liability on unrepatriated foreign earnings.

PRETAX ESTIMATE AVOID3: Tax avoidance related to estimated unrecognized tax liability on unrepatriated foreign earnings. PRETAX - Estimate based on Bauman and Shaw (2008) estimation method. OTHER AVOID3: Tax avoidance unrelated to specific methods of tax avoidance $=35 \%$-adjusted CETR. Tobin's Q: Ratio of market value of firm to book value of firm $=\left((\mathrm{AT})+\left(\left(\mathrm{PRCC} \_\mathrm{C}\right) *(\mathrm{CSHO})\right)-(\mathrm{CEQ})\right) /(\mathrm{AT})$. Options: Average annual value realized from the exercise of options for the top five executives of options by the top five executives grossed up by the fraction of options owned by the covered executives in year $\mathrm{t}-1$ (Execucomp). PPE: Property, plant and equipment, gross $=($ PPEGT $/$ ATt-1). Foreign Income: Pre-tax income from foreign operations $=($ PIFO/ATt-1). Size: Total Sales (SALE). Risk: Standard deviation of monthly stock returns over previous 36 months $($ CRSP). Growth: 3 year average sales growth from $t-2$ to $t=\sum t-2, t($ SALEt - SALEt-1)/SALEt-1. Leverage: Long-term Debt $=($ DLTT+DLC $) /($ AT $)$. NOL: NOL Carryforward/Total Assets $=(T L C F / A T)$. Intangible: Intangible assets $=($ INTAN/ATt-1). Firm Age: $\operatorname{Ln}(1+$ number of years listed in Compustat). Cash: Total Cash $=(\mathrm{CHE} / \mathrm{ATt}-1)$. Appreciation: cumulative stock price appreciation over prior four years $=($ Price $\mathrm{t}-1-$ Price $\mathrm{t}-3) /$ Price $\mathrm{t}-3$. Industry controls based on Barth, Cram and Nelson (2001) and Rees and Sivaramakrishnan (2007). 